This document was prepared in conjunction with work accomplished under Contract No. DE-AC09-96SR18500 with the U. S. Department of Energy.

\title{
DISCLAIMER
}

This report was prepared as an account of work sponsored by an agency of the United States Government. Neither the United States Government nor any agency thereof, nor any of their employees, makes any warranty, express or implied, or assumes any legal liability or responsibility for the accuracy, completeness, or usefulness of any information, apparatus, product or process disclosed, or represents that its use would not infringe privately owned rights. Reference herein to any specific commercial product, process or service by trade name, trademark, manufacturer, or otherwise does not necessarily constitute or imply its endorsement, recommendation, or favoring by the United States Government or any agency thereof. The views and opinions of authors expressed herein do not necessarily state or reflect those of the United States Government or any agency thereof.

This report has been reproduced directly from the best available copy.

Available for sale to the public, in paper, from: U.S. Department of Commerce, National Technical Information Service, 5285 Port Royal Road, Springfield, VA 22161, phone: (800) 553-6847, fax: (703) 605-6900

email: orders@ntis.fedworld.gov

online ordering: http://www.ntis.gov/help/index.asp

Available electronically at http://www.osti.gov/bridge

Available for a processing fee to U.S. Department of Energy and its contractors, in paper, from: U.S. Department of Energy, Office of Scientific and Technical Information, P.O. Box 62, Oak Ridge, TN 37831-0062,

phone: (865)576-8401,

fax: (865)576-5728

email: $\underline{\text { reports@ adonis.osti.gov }}$ 
Key Words:

Pilot-Scale Evaporator

WTP Simulants

LAW Feed Evaporator

Melter Feed Evaporator

Antifoam Agent

Decontamination Factor

Demister

\title{
Retention:
}

Permanent

Key WTP R\&T References:

Test Specification

24590-WTP-TSP-RT-01-020, Rev 0

Test Plan WSRC-TR-2001-00183,

SRT-RPP-2001-00039

R\&T Focus Area Evaporation

Test Scoping Statement

112, Pilot Evaporation

\section{WTP PILOT-SCALE EVAPORATION TESTS (U)}

\author{
Zafar H. Qureshi \\ Duane Adamson \\ William E. Daniel \\ Michael E. Stone \\ Michael R. Williams
}

\section{MARCH 2004}

Westinghouse Savannah River Company

Savannah River Site

Aiken, SC 29808

Prepared for the U.S. Department of Energy Under Contract Number DE-AC09-96SR18500

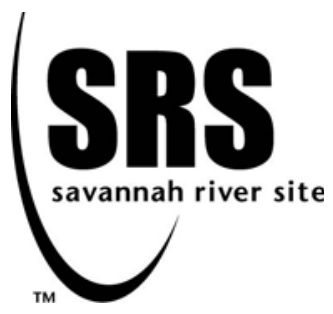


WSRC-TR-2003-00561, REVISION 0

SRT-RPP-2003-00244, REVISION 0

\section{TABLE OF CONTENTS}

LIST OF FIGURES ...................................................................................................................... iv

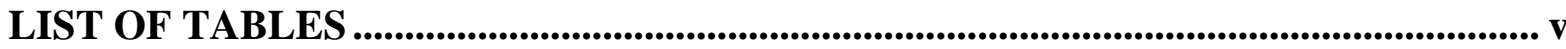

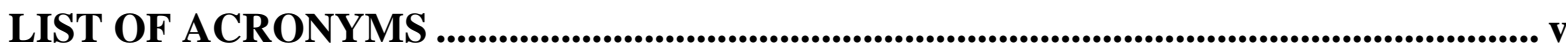

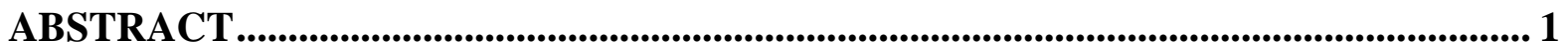

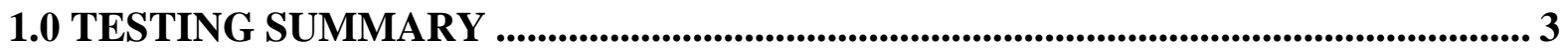

1.1 OBJECTIVES............................................................................................................. 3

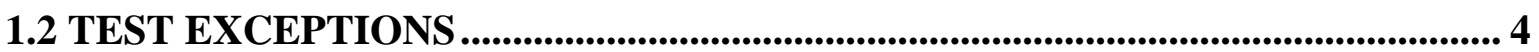

1.3 RESULTS AND PERFORMANCE AGAINST SUCCESS CRITERIA .................. 4

1.4 QUALITY REQUIREMENTS........................................................................................... 5

1.5 R\&T TEST CONDITIONS ............................................................................................... 5

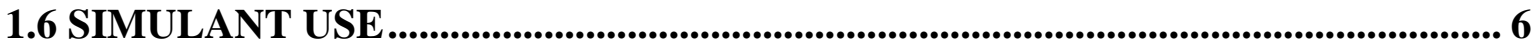

1.7 DISCREPANCIES AND FOLLOW-ON TESTS ........................................................... 7

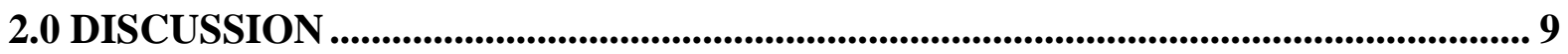

2.1 TEST PROGRAM OBJECTIVES .................................................................................. 9

2.2 BACKGROUND AND PREVIOUS WORK ................................................................ 9

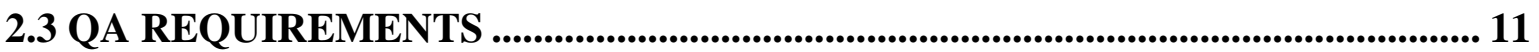

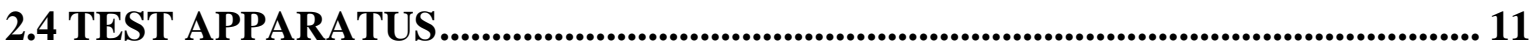

2.4.1 Scaling Considerations........................................................................................................ 12

2.4.2 Test Apparatus Description......................................................................................... 13

2.5 TEST OPERATING CONDITIONS............................................................................ 16

2.5.1 Batch Mode of Operation .............................................................................................. 16

2.5.2 Recirculation Mode of Operation ................................................................................. 19

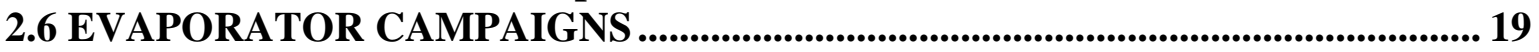

2.6.1 Evaporator Operation........................................................................................ 19

2.6.2 Sampling Methods................................................................................................... 20

2.6.3 Water Tests .......................................................................................................... 21

2.6.4 Test 1- Simulated Ultrafiltration Recycles with HLW SBS from Duratek...... 21

2.6.5 Test 2 - Treated AN102 \& Envelope C LAW SBS from Duratek........................ 24

2.7 TEST RESULTS............................................................................................................ 28

2.7.1 Foaming/Antifoam Results .................................................................................... 28

2.7.2 Decontamination Factors (DF) for Cesium................................................................. 32

2.7.3 Composition Changes During Long Term Testing ................................................... 33

2.7.4 Organic Partitioning ................................................................................................ 49

2.7.5 Formation of Solids and Fouling............................................................................. 52

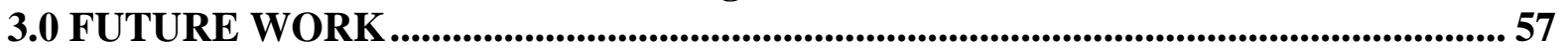

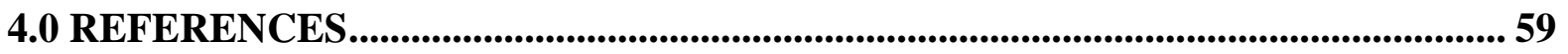

APPENDIX A. RECIPE FOR FIRST WASH ........................................................................ 61

APPENDIX B. RECIPE FOR SECOND WASH..................................................................... 63

APPENDIX C. RECIPE FOR LEACH ..........................................................................6 65

APPENDIX D. RECIPE FOR ACID CLEANING SOLUTION....................................... 67 


\section{LIST OF FIGURES}

Figure 2-1. Process Diagram for Pilot-Scale Evaporator System.......................................... 15

Figure 2-2. Pilot-Scale Evaporator Elevations Details ................................................... 18

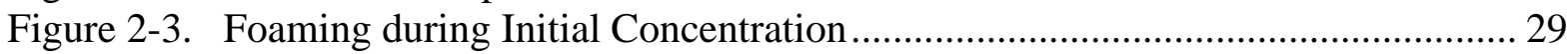

Figure 2-4. Foam Height Before Antifoam Addition ......................................................... 30

Figure 2-5. Foam Height After 100 ppm Antifoam Addition............................................... 31

Figure 2-6. Foam Height After $200 \mathrm{ppm}$ Antifoam Addition.............................................. 31

Figure 2-7. Foam Height After 300 ppm Antifoam Addition.............................................. 32

Figure 2-8. Na Molarity of Evaporator Feed (F), Concentrate Tank (CT), Primary

Condensate Tank (PCT), and Secondary Condensate Tank (SCT) during Test 2 ........... 33

Figure 2-9. Evaporator Test 2 Average Mass Flow Rates ................................................... 34

Figure 2-10. Evaporator Run 2 Feed (F) Concentrations in ppm for Small Changing Cations

Figure 2-11. Evaporator Run 2 Concentrate Tank (CT) Concentrations in ppm for Small

Changing Cations ......................................................................................................... 35

Figure 2-12. Evaporator Run 2 Primary Condensate Tank (PCT) Concentrations in ppm for

Small Changing Cations ............................................................................................. 36

Figure 2-13. Evaporator Run 2 Secondary Condensate Tank (SCT) Concentrations in ppm

for Small Changing Cations ………………………............................................. 36

Figure 2-14. Evaporator Run 2 Feed (F) Concentrations in ppm for Medium Changing

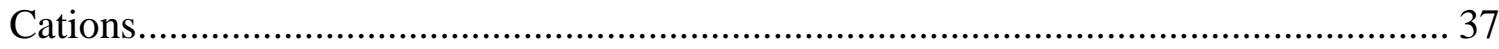

Figure 2-15. Evaporator Run 2 Concentrate Tank (CT) Concentrations in ppm for Medium

Changing Cations ....................................................................................................... 37

Figure 2-16. Evaporator Run 2 Primary Condensate Tank (PCT) Concentrations in ppm for

Medium Changing Cations ...................................................................................... 38

Figure 2-17. Evaporator Run 2 Secondary Condensate Tank (SCT) Concentrations in ppm

for Medium Changing Cations.................................................................................... 38

Figure 2-18. Evaporator Run 2 Feed (F) Concentrations in ppm for Large Changing Cations

Figure 2-19. Evaporator Run 2 Concentrate Tank (CT) Concentrations in ppm for Large

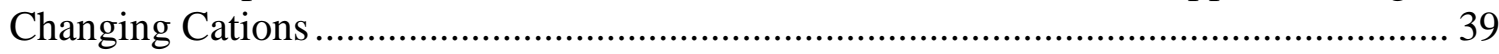

Figure 2-20. Evaporator Run 2 Primary Condensate Tank (PCT) Concentrations in ppm for

Large Changing Cations............................................................................................... 40

Figure 2-21. Evaporator Run 2 Secondary Condensate Tank (SCT) Concentrations in ppm

for Large Changing Cations ....................................................................................... 40

Figure 2-22. Evaporator Run 2 Feed Concentrations in ppm for Small Changing Anions .. 41

Figure 2-23. Evaporator Run 2 Concentrate Tank Concentrations in ppm for Small

Changing Anions

Figure 2-24. Evaporator Run 2 Feed Concentrations in ppm for Medium Changing Anions

Figure 2-25. Evaporator Run 2 Concentrate Tank Concentrations in ppm for Medium

Changing Anions ................................................................................................... 42

Figure 2-26. Evaporator Run 2 Feed Concentrations in ppm for Large Changing Anions .. 43

Figure 2-27. Evaporator Run 2 Concentrate Tank Concentrations in ppm for Large

Changing Anions 


\section{LIST OF TABLES}

Table 2-1. Comparison of Full-Scale vs. Pilot-Scale Design Parameters........................... 14

Table 2-2. Equipment Designation .............................................................................. 17

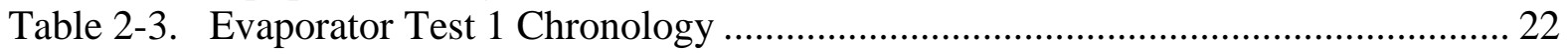

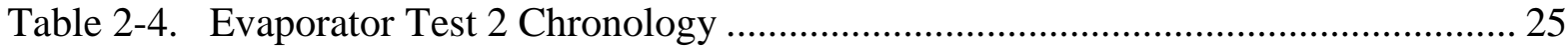

Table 2-5. Cesium Results and Decontamination Factor............................................... 32

Table 2-6. Evaporator Run 2 Cation Analyses for Feed and Concentrate Tank (CT)......... 44

Table 2-7. Evaporator Run 2 Cation Analyses for Primary (PCT) and Secondary (SCT)

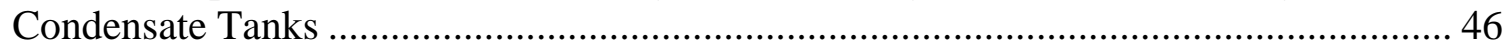

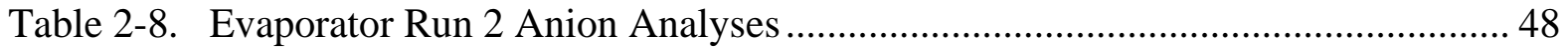

Table 2-9. Organic Spike in 10-ml Ampoules .................................................................. 49

Table 2-10. Percent Organic Partitioning Across Pilot Evaporator ...................................... 51

Table 2-11. Percent Organic Partitioning Across OLI Modeled Evaporator....................... 51

Table 2-12. OLI Evaporator Modeling Parameters ........................................................ 51

Table 2-13. Mass Organic Partitioning Across Pilot Evaporator ...................................... 52

Table 2-14. Solids in the Evaporator Run 1 Samples ................................................... 53

Table 2-15. Solids in Evaporator Run 2 Samples ........................................................... 55

\section{LIST OF ACRONYMS}

$\begin{array}{ll}\text { ADS } & \text { Analytical Development Section } \\ \text { DAS } & \text { Data Acquisition System } \\ \text { DF } & \text { Decontamination Factor } \\ \text { DOE } & \text { Department of Energy } \\ \text { EDL } & \text { Engineering Development Laboratory } \\ \text { FEP } & \text { Feed Evaporation Process } \\ \text { HLW } & \text { High Level Waste } \\ \text { RPP } & \text { River Protection Project } \\ \text { SBS } & \text { Submerged Bed Scrubber } \\ \text { TLP } & \text { Treated LAW Evaporation Process } \\ \text { UF } & \text { Ultra Filtration } \\ \text { WTP } & \text { Waste Treatment Plant }\end{array}$


WSRC-TR-2003-00561, REVISION 0

SRT-RPP-2003-00244, REVISION 0

This page intentionally left blank.

- vi - 


\begin{abstract}
This report documents the design, assembly, and operation of a Pilot-Scale Evaporator built and operated by SRTC in support of Waste Treatment Plant (WTP) Project at the DOE's Hanford Site. The WTP employs three identical evaporators- two for the Waste Feed and one for the Treated LAW. The Pilot-Scale Evaporator was designed to test simulants for both of these waste streams.

The Pilot-Scale Evaporator is 1/76th scale in terms of evaporation rates. The basic configuration of forced circulation vacuum evaporator was employed. A detailed scaling analysis was performed to preserve key operating parameters such as basic loop configuration, system vacuum, boiling temperature, recirculation rates, vertical distances between important hardware pieces, reboiler heat transfer characteristics, vapor flux, configuration of demisters and water spray rings.
\end{abstract}

Three evaporation test campaigns were completed. The first evaporation run used water in order to shake down the system. The water runs were important in identifying a design flaw that inhibited mixing in the evaporator vessel, thus resulting in unstable boiling operation. As a result the loop configuration was modified and the remaining runs were completed successfully.

Two simulant runs followed the water runs. Test 1: Simulated Ultrafiltration Recycles with HLW SBS, and Test 2: Treated AN102 with Envelop C LAW). Several liquid and offgas samples were drawn from the evaporator facility for regulatory and non-regulatory analyses. During Test 2, the feed and the concentrate were spiked with organics to determine organic partitioning. The decontamination factor (DF) for Test 1 was measured to be 110,000 (more than the expected value of 100,000).

Dow Corning Q2-3183A antifoam agent was tested during both Tests1 \& 2. It was determined that $500 \mathrm{ppm}$ of this antifoam agent was sufficient to control the foaminess to less than $5 \%$ of the liquid height.

The long-term testing (around 100 hours of operation) did not show any fouling of reboiler or other loop piping.

The Pilot-Scale Evaporator will be used in the Semi-Integrated Pilot Plant tests. Additionally, the Pilot-Scale design can easily accommodate hardware changes that result from the development of the full-scale evaporator to resolve any issues arising from the startup or operation of the full-scale facility. 
WSRC-TR-2003-00561, REVISION 0

SRT-RPP-2003-00244, REVISION 0

This page intentionally left blank. 
WSRC-TR-2003-00561, REVISION 0

SRT-RPP-2003-00244, REVISION 0

\subsection{TESTING SUMMARY}

The Engineering Development Lab (EDL) of Savannah River Technology Center (SRTC) designed, built, and operated a Pilot-Scale Evaporator in support of RPP's Waste Treatment Plant (WTP). The following sections provide a summary of pilot scale evaporation testing.

\subsection{OBJECTIVES}

The Pilot-Scale Evaporator was designed and operated to meet the following objectives as stated in the Test Specification.

Objective 1: Design, procure, and construct a forced circulating vacuum evaporator to be used for pilot scale evaporations tests at the SRTC. The pilot-scale evaporation system will be designed to pilot the Waste Feed and the Treated LAW Evaporators.

Discussion: Objective 1 was met and a 1/76th scale (based upon evaporation rate) evaporator was designed, fabricated, and successfully operated to run the prescribed evaporation campaigns.

Objective 2: Conduct at least three simulant tests using approved simulants of Envelope A, $\mathrm{B}$, and/or C wastes with appropriate simulants of the WPT recycle streams. An additional Cesium (Cs) or Technetium (Tc) eluate evaporation test may also be conducted if deemed necessary by the WTP project.

Discussion: The third campaign was not required since Envelope $\mathrm{C}$ was expected to bound the performance of the other two waste types. Consequently, the test matrix was reduced to run only two simulant runs (Test 1: Simulated Ultrafiltration Recycles with HLW SBS, and Test 2: Treated AN102 with Envelop C LAW). Additionally, water runs were added to shake down the system and test hardware configuration. All three evaporation runs were completed successfully.

Objective 3: Determine the fate of separable organics (both tributyl phosphate and normal paraffin hydrocarbon) in the evaporator system.

Discussion: This objective was met by spiking the concentrate with separable organics during Test 2. Both liquid and offgas samples were analyzed for regulatory purposes.

Objective 4: Measure and analyze the simulant pilot scale test data.

Discussion: The Pilot-Scale Test Facility is fully instrumented to indicate and record flow rates of various streams system parameters such as pressure, temperature, and density. Several sample ports provided necessary samples for analyses. 
Objective 5: Sample and analyze the composition of the Feed, Concentrate, Condensate, and Offgas for target constituents of regulatory concern by EPA SW-846 methods.

Discussion: In addition to in-house analyses, select samples were drawn and analyzed for regulatory purposes following the prescribed methods.

Objective 6: Report test results.

Discussion: This final report documents the results of all testing. Additionally, results of scaling analysis and preliminary assessment of Test 1 results were communicated during the course of the test program.

\subsection{TEST EXCEPTIONS}

The Test Specification specified three evaporation test campaigns using approved simulants of Envelope A, B, and/or C wastes with appropriate simulants of the WPT recycle streams. Additionally, Cs or Tc eluate evaporation test was also projected if deemed necessary by the WTP project. Once the test facility design and fabrication was complete, WTP project reduced the test matrix to run only two simulant runs (Simulated Ultrafiltration Recycles with HLW SBS and Treated AN102 with Envelop C LAW). Additionally, water runs were added to shake down the system and test hardware configuration.

\subsection{RESULTS AND PERFORMANCE AGAINST SUCCESS CRITERIA}

The results of the evaporator tests are compared below against the success criteria provided in the Test Specification.

\begin{tabular}{|l|l|}
\hline \multicolumn{1}{|c|}{ Success Criteria } & \multicolumn{1}{c|}{ Discussion } \\
\hline $\begin{array}{l}\text { 1. Demonstrate that the Decontamination } \\
\text { Factor (DF) is acceptable. }\end{array}$ & $\begin{array}{l}\text { The DF for Test 1 was found to be } \\
111,000 \text { which was found to be acceptable } \\
\text { for the 2-demisters design configuration. }\end{array}$ \\
\hline $\begin{array}{l}\text { 2. Test antifoam agent (recommended by } \\
\text { bench-scale tests) performance to ensure } \\
\text { that the foam level to be less than 5\% of } \\
\text { the liquid height in the evaporator vessel } \\
\text { The recommended antifoam agent (Dow } \\
\text { Corning Q2-3183A) was used for both } \\
\text { Tests 1 \& 2. The recommended } \\
\text { concentration was 1400 ppm. Both Tests } \\
1 \& \text { 2 showed that around 500 ppm of } \\
\text { antifoam was effective to control the foam } \\
\text { level to less than 1 ft for a liquid height of } \\
22 \mathrm{ft} \text { (<5\% foam height). Since only two } \\
\text { simulants were evaporated under this } \\
\text { report, the antifoam concentrations for the } \\
\text { full-scale operation must be guided by the } \\
\text { bench scale tests covering a wider variety } \\
\text { of waste simulants. }\end{array}$ \\
\hline
\end{tabular}


WSRC-TR-2003-00561, REVISION 0

SRT-RPP-2003-00244, REVISION 0

\begin{tabular}{|l|l|}
\hline \multicolumn{1}{|c|}{ Success Criteria } & \multicolumn{1}{c|}{ Discussion } \\
\hline 3. Are operating parameters achievable? & $\begin{array}{l}\text { The Pilot-Scale evaporator tests } \\
\text { demonstrated that the operating } \\
\text { parameters such as system vacuum, steady } \\
\text { boiling, feed and concentrate removal are } \\
\text { achievable. The water tests identified an } \\
\text { earlier design flaw that resulted in } \\
\text { unsteady boiling. The modified design } \\
\text { resulted in steady and stable operation }\end{array}$ \\
\hline
\end{tabular}

\subsection{QUALITY REQUIREMENTS}

This work was conducted in accordance with the RPP-WTP QA requirements specified for work conducted by SRTC as identified in DOE IWO MOSRLE60. SRTC has provided matrices to WTP demonstrating compliance of the SRTC QA program with the requirements specified by WTP. Specific information regarding the compliance of the SRTC QA program with RW-0333P, Revision 10, NQA-1 1989, Part 1, Basic and Supplementary Requirements and NQA-2a 1990, Subpart 2.7 is contained in these matrices.

\subsection{R\&T TEST CONDITIONS}

\begin{tabular}{|l|l|}
\hline \multicolumn{1}{|c|}{ R\&T Test Conditions } & \multicolumn{1}{c|}{ Discussion } \\
\hline $\begin{array}{l}\text { 1. Design, fabricate and operate a forced } \\
\text { circulation vacuum evaporator rig. }\end{array}$ & $\begin{array}{l}\text { Based upon the available design } \\
\text { information, SRTC successfully designed } \\
\text { and operated a forced circulation vacuum } \\
\text { evaporator rig. A scaling analysis was } \\
\text { performed and approved by R\&T } \\
\text { customer. }\end{array}$ \\
\hline $\begin{array}{l}\text { 2. Consult vendor on mist eliminator } \\
\text { design. }\end{array}$ & $\begin{array}{l}\text { SRTC contracted Otto York to design and } \\
\text { supply mist eliminators for the Pilot-Scale } \\
\text { evaporator. }\end{array}$ \\
\hline $\begin{array}{l}\text { 3. Conduct three evaporation test } \\
\text { campaigns using approved simulants of } \\
\text { Envelope A, B, and/or C wastes with } \\
\text { appropriate simulants of the WPT recycle } \\
\text { streams. Additionally, perform Cs or Tc } \\
\text { eluate evaporation test if deemed necessary } \\
\text { by the WTP project. }\end{array}$ & $\begin{array}{l}\text { Once the test facility design and } \\
\text { fabrication was complete, WTP project } \\
\text { reduced the test matrix to run only two } \\
\text { simulant runs (Simulated Ultrafiltration } \\
\text { Recycles with HLW SBS and Treated } \\
\text { AN102 with Envelop C LAW). The third } \\
\text { campaign was not required since Envelop } \\
\text { C was expected to bound the performance } \\
\text { of the other two waste types. Additionally, } \\
\text { water runs were added to shakedown the } \\
\text { system and test hardware configuration. }\end{array}$ \\
\hline
\end{tabular}


WSRC-TR-2003-00561, REVISION 0

SRT-RPP-2003-00244, REVISION 0

\begin{tabular}{|l|l|}
\hline \multicolumn{1}{|c|}{ R\&T Test Conditions } & \multicolumn{1}{c|}{ Discussion } \\
\hline 4. Test antifoam agent performance. & $\begin{array}{l}\text { The antifoam agent was able to control the } \\
\text { foaminess within the specified limit of } \\
5 \% .\end{array}$ \\
\hline $\begin{array}{l}\text { 5. Confirm that operating parameters are } \\
\text { achievable. }\end{array}$ & $\begin{array}{l}\text { The Pilot-Scale evaporator successfully } \\
\text { achieved all the specified operating } \\
\text { parameters such as vacuum, temperatures, } \\
\text { flow rates, and vapor flux. }\end{array}$ \\
\hline $\begin{array}{l}\text { 6. Spike the feed/concentrate with organics } \\
\text { and analyze various stream for analyses. }\end{array}$ & $\begin{array}{l}\text { The feed/concentrate was spiked and } \\
\text { samples were analyzed for regulatory and } \\
\text { non-regulatory purposes. }\end{array}$ \\
\hline $\begin{array}{l}\text { 7. Be prepared to operate the pilot scale } \\
\text { evaporator with a simulant of Cs or Tc } \\
\text { eluate to confirm bench scale results and } \\
\text { model development. }\end{array}$ & $\begin{array}{l}\text { The pilot-scale evaporator stands ready for } \\
\text { any simulant feed. However, Cs simulant } \\
\text { or Tc eluate runs were not requested to be } \\
\text { made. }\end{array}$ \\
\hline
\end{tabular}

\subsection{SIMULANT USE}

WTP customer approved all simulants used in the evaporation task. These simulants were either prepared at the Engineering Development Lab or acquired from other RPP programs as described below. The following three evaporation test campaigns were successfully completed.

- Water runs. The water runs were added to the original test matrix in order to shake down the system and test hardware configuration.

- Test 1. Simulated Ultrafiltration Recycles with HLW SBS. The simulants for ultrafiltration recycles were prepared in the Engineering Development Lab (EDL) following an approved recipe and mixing protocol. Duratek supplied the HLW SBS.

- Test 2. Treated AN-102 with Envelop C LAW SBS. The Treated AN-102 was generated by the precipitation and filtration processes completed earlier in the EDL. Duratek supplied the Envelop C LAW SBS. 


\subsection{DISCREPANCIES AND FOLLOW-ON TESTS}

The full-scale evaporator designs (both for Waste Feed and Treated LAW) were not available when the Pilot-Scale evaporator design was underway. WTP customer advised SRTC to proceed with the Pilot-Scale design based upon the available information. Later, WTP customer provided SRTC a copy of the Engineering Specification prepared for full-scale evaporator vendor. The operating parameters such as system pressure, temperatures, and concentration factors for the Pilot-Scale are similar to those for the full-scale ones. However, the system hardware discrepancies will be identified only after the full-scale design by the vendor is complete and available. The Pilot-Scale evaporator yielded lower values of decontamination factors. This would require hardware modifications in the vapor space of the evaporator vessel. The Pilot-Scale evaporator hardware can be easily modified once the full-scale design is finalized and available.

It is planned to use the existing evaporator setup during the upcoming integrated tests. 
WSRC-TR-2003-00561, REVISION 0

SRT-RPP-2003-00244, REVISION 0

This page intentionally left blank. 
WSRC-TR-2003-00561, REVISION 0

SRT-RPP-2003-00244, REVISION 0

\subsection{DISCUSSION}

\subsection{TEST PROGRAM OBJECTIVES}

The Pilot-Scale Evaporator was designed and operated to meet the following objectives as stated in the Test Specification.

- Design, procurement, and construction of a pilot LAW forced circulating vacuum evaporator that will be used for pilot scale evaporations tests at the SRTC Thermal Fluids Laboratory. The pilot-scale evaporation system will be designed to pilot the LAW Feed and Melter Feed Evaporators.

- Conduct at least three simulant tests using approved simulants of Envelope A, B, and/or C wastes with appropriate simulants of the WPT recycle streams. An additional Cs or Tc eluate evaporation test may also be conducted if deemed necessary by the WTP project.

- Determine the fate of separable organics (both tributyl phosphate and normal paraffin hydrocarbon) in the evaporator system.

- Measure and analyze the simulant pilot scale test data.

- Sample and analyze the composition of the Feed, Concentrate, Condensate, and Offgas for target constituents of regulatory concern by EPA SW-846 methods.

- Report test results.

\subsection{BACKGROUND AND PREVIOUS WORK}

The objective of the River Protection Project Waste Treatment Plant (RPP-WTP) is to build a vitrification plant at the Hanford Site to stabilize the radioactive waste currently stored in large tanks at that site. Prior to the vitrification process, the stored waste undergoes various waste treatment processes including evaporation. The process flowsheet includes two separate evaporators -Low Activity Waste (LAW) Feed Evaporator and LAW Melter Feed Evaporator. The pilot-scale evaporation tests will be conducted at EDL to provide operational and regulatory compliance test data simulating the LAW Feed and Melter Feed Evaporator process conditions.

Low Activity Waste (LAW) solutions have been evaporated at the Hanford site using forced circulation evaporators since the 1960s. Many of the LAW solutions stored in the doubleshell tanks were evaporated in the 242-A evaporator / crystallizer, which is a forced circulation evaporator. The WTP LAW Feed Evaporator and LAW Melter Feed Evaporator are of a design similar to that of the 242-A evaporator. As such, a large set of data is available in Hanford site records concerning the evaporation of LAW solutions. However, the WTP will mix recycle waste solutions from the HLW and LAW vitrification processes with the LAW feed solutions. Evaporation of these mixtures is likely to differ from the evaporation of only LAW solutions. Additionally, the WTP must evaluate the expected discharges from the Waste Feed Evaporator and the Treated LAW Evaporator to an offgas treatment system and the 200-East Area Liquid Effluent Treatment Facility in support of regulatory permit applications. 
During the previous phase of the project, the WTP began a process to collect information on the evaporation characteristics (e.g., tendency to foam, solubility) of LAW solutions, (Monson 2000) and (Calloway 2000), as well as provide information to assess compliance of non-condensable and condensate waste streams with regulatory permits. This information was used to prepare an initial model of the LAW melter feed evaporator system using the OLI Corporation Environmental Simulation Program (ESP) (Choi 1999).

SRTC also conducted bench scale evaporation experiments using simulants and radioactive samples (Calloway et al 2000), (Calloway 2000), and (Crawford et al 2001). Envelope C simulated evaporator feed was spiked with a group of organic chemicals that chemically represent the various volatile and semi-volatile organics found in Hanford waste (Saito 2001). The evaporator concentrate, condensate, and offgas were sampled using EPA SW-846 sampling and analysis methods. Additionally, SRTC evaporated a radioactive sample of Hanford waste from tank 241-AN102 (Crowder et al 2001) (Ferrara et al 2001). The radioactive evaporator feed, concentrate, and condensate were also sampled using EPA SW-846 methods and analyzed for volatile, semi-volatile, radionuclides and metals. The purpose of both experiments was to determine the expected distribution of hazardous species throughout the evaporator system. The distribution of volatile and semi-volatile organics in the evaporator offgas is a function of both vapor pressure of the chemical species and the physical entrainment associated with the evaporator. Entrainment is dependent on the scale and physical arrangement of the evaporator system scale and was at best only partially approximated in the B1 tests conducted at SRTC.

Since this data will be used to support risk assessment and air permit preparation activities for WPT, pilot-scale testing is needed to support the modeling efforts conducted by SRTC during Part B1. It is expected that a pilot-scale system will more closely approximate the expected entrainment of a full-scale evaporator system. The WPT environmental team will use the SRTC model and pilot-scale data developed by this test specification to support risk assessment and air permit preparation activities.

SRTC conducted evaporation studies using both simulants and actual Hanford tank samples. The WPT LAW evaporators will process actual Hanford tank waste plus a combination of recycle stream that will be generated from the WPT Vitrification (HLW and LAW Submerged Bed Scrubber Condensate) and Pretreatment (e.g., HLW/LAW Ultrafiltration Permeate, Ion Exchange Recycle flush liquors) Plants. The SRTC testing conducted in Part B1 did not include the expected WPT recycle streams. The pilot evaporator system will be used to conduct integrated testing in which expected recycle streams will be added to simulated LAW feed. The ratio of recycle to feed volume will be varied over the expected range of operations. 
Envelope C simulants of 241-AN-107 and radioactive samples of 241-AN-102 were found to foam significantly during atmospheric and vacuum evaporation bench scale tests (Crowder et al 2001). Bench-scale vacuum evaporation tests conducted with Envelope A (241-AN-105) and B (241-AZ-101) simulants did not show any significant foaming. Radioactive and bench evaporation tests conducted by SRTC and PNNL were not conducted at the design basis vaporization flux (kg vapor/s/boiling surface area) Therefore, these tests only provided a qualitative means of determining the foaming potential of the waste and the effectiveness of the antifoam agents employed during the experiments. Foaming studies conducted for the DWPF have shown that the design basis vaporization flux is required to fully characterize the foaming in waste evaporators (Koopman 2000). Anti-foam reagent screening studies are presently in progress at the Illinois Institute of Technology, a subcontractor to SRTC. Conformation testing of these reagents will be performed at SRTC.

\subsection{QA REQUIREMENTS}

This work was conducted in accordance with the RPP-WTP QA requirements specified for work conducted by SRTC as identified in DOE IWO MOSRLE60. SRTC has provided matrices to WTP demonstrating compliance of the SRTC QA program with the requirements specified by WTP. Specific information regarding the compliance of the SRTC QA program with RW-0333P, Revision 10, NQA-1 1989, Part 1, Basic and Supplementary Requirements and NQA-2a 1990, Subpart 2.7 is contained in these matrices.

\subsection{TEST APPARATUS}

The Pilot-Scale Evaporator was designed to establish evaporation conditions similar to those of the full-scale system. In order to achieve this, it is important to identify key operating parameters in the full-scale process and then duplicate these conditions in the Pilot-Scale as closely as possible. At the time when the Pilot Scale Evaporator was in design planning stages, the full-scale evaporator design was not available. Only some preliminary design information was available based upon experience with the existing evaporators. In fact, the full-scale evaporator was identified as a procured system from a vendor and the vendor's procurement package was under preparation when the Pilot-Scale was being designed. RPP customer advised SRTC to initiate the Pilot-Scale based upon the available information at that time.

The RPP customer provided the following preliminary drawings for the full-scale system.

- $\quad$ SK-W375-PT-M00021

- $\quad$ SK-W375-PT-M00016

- SK-W375-PT-M00006

- SK-W375-PT-M00025
V11002 Recirculation Vessel, System PT-120

E11001 Reboiler, System PT-120

E11003 After-Condenser, System PT-120

Equipment Envelope/Hydraulic Profile, Single Pass Reboiler

The operating parameters such as pressure, temperature, evaporation rates and flow rates were guided by the Engineering Specification for Forced Circulation Vacuum Evaporator Systems (Spec. No. 24590-PTF-3PS-MEVV-T0001). 


\subsubsection{Scaling Considerations}

Based upon the information provided in the drawings and the Test Specification, a scaling analysis was conducted to determine key design parameters for the Pilot-Scale Evaporator. Key process conditions that influence the evaporation process were identified. These are listed and discussed in this section.

\subsubsection{System Pressure}

The boiling temperature of aqueous solutions is a strong function of the system pressure. As the pressure decreases, the boiling temperature also decreases. Water that boils at $100{ }^{\circ} \mathrm{C}$ at 14.7 psia, boils at only $38.4{ }^{\circ} \mathrm{C}$ at 1 psia. Note that the waste simulants have higher boiling temperatures than water at a given pressure, however, the temperature-pressure relationship is similar. The waste simulants used in this study boiled around $45^{\circ} \mathrm{C}$ at 1 psia. The difference between this temperature and the water boiling temperature at the same pressure is commonly known as the boiling point elevation. The boiling point elevation is somewhat influenced by the chemical composition of the solution.

In order to achieve prototypic evaporation conditions, it is important to preserve the pressure levels at the boiling interface. The system was designed to achieve 1 psia nominal pressure in the vapor space of the evaporator vessel. Additionally, in order to preclude any premature flashing, the balance of the system must be kept at a higher pressure. This was achieved by placing all the recirculation loop piping, reboiler, and the recirculation pump well below the boiling surface. The exit of the reboiler was specified to be $10 \mathrm{ft}$ below the minimum liquid level in the evaporator vessel.

Another consequence of the low system pressure is the placement of the primary condenser. In order to gravity draw condensate out of the primary condenser at low pressure of 1 psia, the condenser must be placed at barometric heights. Consequently, the lowest point of the condenser was placed about $32 \mathrm{ft}$ above the primary condensate tank level and the condensate was collected through a constant level dip tube arrangement in the condensate catch tanks.

\subsubsection{Vapor Flux}

Vapor flux is the rate of evaporation per unit area of the boiling surface (mass rate per unit surface area). When divided by the vapor density at the operating pressure, it yields the vapor velocity at the boiling interface. Entrainment of liquid droplets by the vapor stream is strongly influenced by the vapor velocity at the interface. Higher vapor velocities result in higher liquid entrainment that in turn may lead to lower values of decontamination factor (DF). The DF for a certain chemical species is defined as its concentration in the concentrate divided by its concentration in the vapor (as measured in its condensate).

The full-scale design has vapor velocities around $10 \mathrm{ft} / \mathrm{s}$. Since one of the main objectives of the pilot-scale testing was to determine the decontamination factors (DF) for various boiling campaigns, it was necessary to preserve these velocity levels in the pilot scale design. 


\subsubsection{Disengagement Zone and Demisters}

The liquid-vapor interface is not a well defined surface. Only under non-boiling conditions, one can expect a clear interface. Under boiling conditions, the region where water vapor disengages from the liquid can be divided into two distinct zones. The first zone is like froth where vapor bubbles and saturated liquid coexist in a very turbulent mixed zone. As soon as boiling ceases, this zone collapses to a well defined liquid-vapor interface. Note that this froth is different from foam that exists even as boiling ceases. The second zone exists just above the froth zone where smaller liquid droplets are entrained by the vapor and the larger droplets fall down under gravity. This zone is termed as the disengagement zone.

The entrained liquid droplets are removed by the downstream demisters. The distances between the liquid-vapor interface and the first demister and between the two demisters are important dimensions to be preserved in a pilot-scale test. Additionally, the thickness of the demister pads and their construction details must be prototypic for a pilot-scale facility. At the time of pilot-scale design, the demister details for the full-scale evaporator were not available. Otto York (well-known manufacturer of demister material) designed and supplied the demister pads for the pilot scale test facility.

Based upon the above considerations and other known geometrical information available, it was decided to preserve all important vertical dimensions in the Pilot-Scale design. The lateral dimensions such as vessel diameter, number or reboiler tubes, and piping diameters were selected to yield the prototypic vapor flux rates. Table 2-1 lists pertinent dimensions and flow parameters for both the full-scale evaporator and the pilot-scale test facility as yielded by the scaling analysis. The percentage of full-scale values is also listed in the table. The final Pilot-Scale design provided a nominal boil-off rate of $0.4 \mathrm{gpm}$ of primary condensate with a maximum boil-off rate of $0.5 \mathrm{gpm}$. Although the nominal system pressure is 1 psia, the Pilot-Scale facility is capable of achieving pressures as low as 0.6 psia.

\subsubsection{Test Apparatus Description}

Figure 2-1 shows the Process and Instrumentation Diagram (P\&ID). The Pilot-Scale Evaporator System consists of many sub-systems provided alphabetically.

- Antifoam System

- Concentrate Loop

- Evaporator Recirculation

- Feed Loop

- House Air

- Jet Pump

- Primary Condensate

- Process Water

- Secondary Condensate

- Steam Generator

- Spray Water 
WSRC-TR-2003-00561, REVISION 0

SRT-RPP-2003-00244, REVISION 0

Table 2-1. Comparison of Full-Scale vs. Pilot-Scale Design Parameters

\begin{tabular}{|c|c|c|c|c|}
\hline Parameter & Units & Full Scale Evap & Pilot scale & $\%$ of Full Scale \\
\hline Evaporator vessel dia & $\mathrm{ft}$ & 13.00 & 1.49 & 11.47 \\
\hline Liquid level range in evap vessel & $\mathrm{ft}$ & 2.92 & 2.92 & 100.00 \\
\hline Min liquid vol. in evap vessel & gal & 11003.31 & 144.78 & 1.32 \\
\hline Max liquid vol. in evap vessel & gal & 13899.13 & 182.88 & 1.32 \\
\hline Min residence time in evap vessel & $\min$ & 1.50 & 1.50 & 100.00 \\
\hline Max recirculation flow rate & gpm & 7335.54 & 96.52 & 1.32 \\
\hline Max residence time in evap vessel & $\min$ & 1.89 & 1.89 & 100.00 \\
\hline Evaporation rate in gpm & gpm & 30.00 & 0.39 & 1.32 \\
\hline Evaporation rate in $1 \mathrm{bm} / \mathrm{sec}$ & $1 \mathrm{bm} / \mathrm{s}$ & 4.17 & 0.05 & 1.32 \\
\hline Enthalpy of evaporation & $\mathrm{kW}$ & 4540.03 & 59.74 & 1.32 \\
\hline Evap vessel $\mathrm{x}$-sectional area & $\mathrm{ft} 2$ & 132.73 & 1.75 & 1.32 \\
\hline Evap vessel opererating pressure & psia & 1.00 & 1.00 & 100.00 \\
\hline Vapor flux & $\mathrm{lbm} / \mathrm{s}-\mathrm{ft} 2$ & 0.03 & 0.03 & 100.00 \\
\hline Vapor velocity at boiling interface & $\mathrm{ft} / \mathrm{s}$ & 10.15 & 10.15 & 100.00 \\
\hline Reboiler tube OD & in & 1.50 & 1.50 & 100.00 \\
\hline Reboiler tube ID & in & 1.33 & 1.33 & 100.00 \\
\hline Flow area/tube & in 2 & 1.40 & 1.40 & 100.00 \\
\hline Number of tubes & & 228.00 & 3.00 & 1.32 \\
\hline Total flow area & $\mathrm{ft} 2$ & 2.21 & 0.03 & 1.32 \\
\hline Tube height & $\mathrm{ft}$ & 7.00 & 7.00 & 100.00 \\
\hline Recirculation flow rate & gpm & 7335.54 & 96.52 & 1.32 \\
\hline Recirculation flow rate & $\mathrm{ft} 3 / \mathrm{s}$ & 16.34 & 0.22 & 1.32 \\
\hline Sp gravity & & 1.33 & 1.33 & 100.00 \\
\hline Receir mass flow rate & $1 \mathrm{bm} / \mathrm{s}$ & 1356.49 & 17.85 & 1.32 \\
\hline Liquid velocity in tubes & $\mathrm{ft} / \mathrm{s}$ & 7.39 & 7.39 & 100.00 \\
\hline Recirculation loop piping ID & in & 19.50 & 2.25 & 11.51 \\
\hline $\begin{array}{l}\text { Recirculation loop piping } \mathrm{x} \text { section } \\
\text { area }\end{array}$ & $\mathrm{ft}^{\wedge} 2$ & 2.07 & 0.03 & 1.33 \\
\hline Velocity in recirculation loop piping & $\mathrm{ft} / \mathrm{s}$ & 7.88 & 7.82 & 99.27 \\
\hline
\end{tabular}


WSRC-TR-2003-00561, REVISION 0

SRT-RPP-2003-00244, REVISION 0

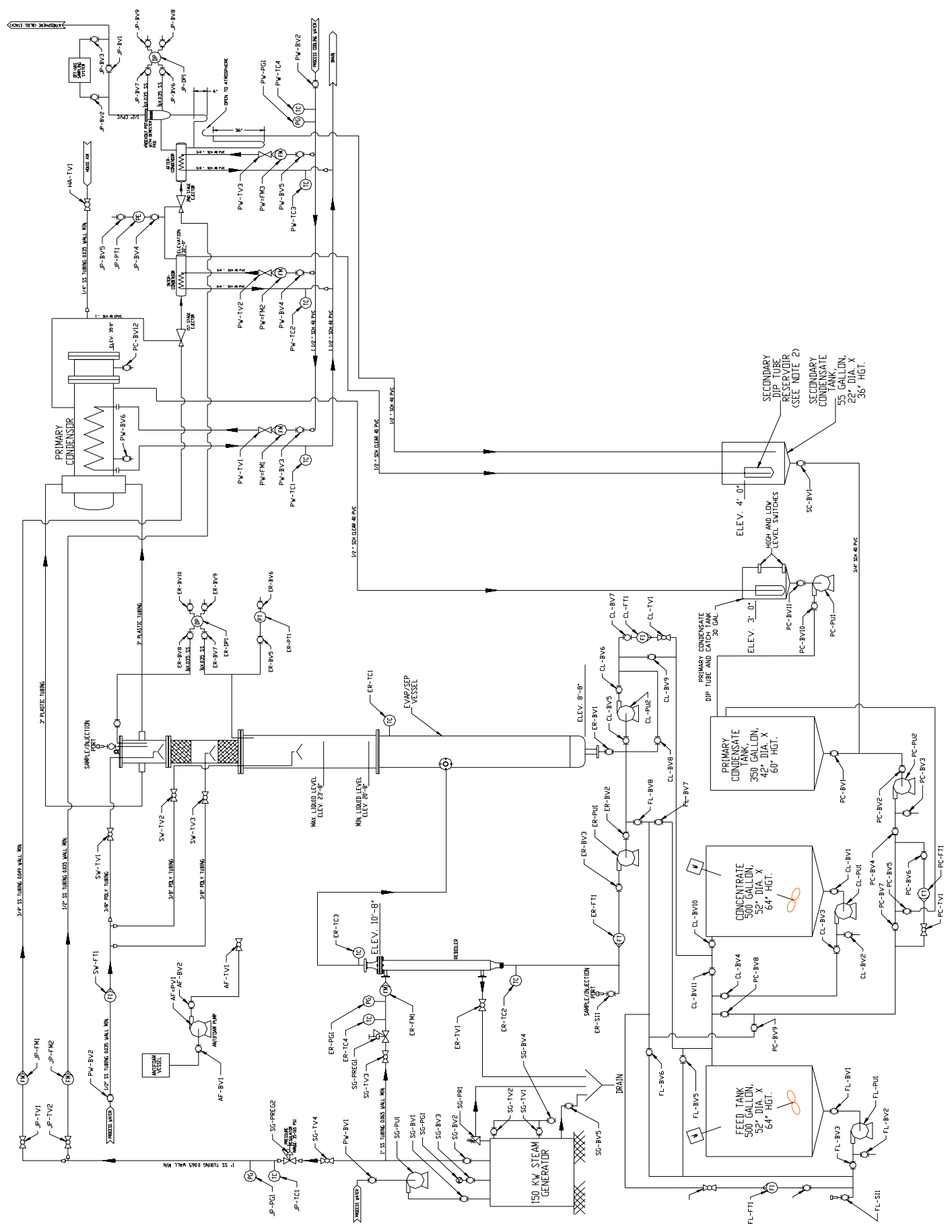

Figure 2-1. Process Diagram for Pilot-Scale Evaporator System 
Typically, each campaign would evaporate about 300 gallons of working fluid (water or waste simulant). The evaporator is a forced circulation evaporator where heat is added in the reboiler that is essentially a shell-and-tube heat exchanger with steam on the shell side. No evaporation occurs in the reboiler due to hydrostatic pressure head. The evaporator vessel is kept under vacuum $(\sim 1 \mathrm{psia})$ and the boiling temperature for water is about $104{ }^{\circ} \mathrm{F}\left(40{ }^{\circ} \mathrm{C}\right)$ at this pressure. The simulant has a boiling point elevation of about $11^{\circ} \mathrm{F}$. Thus the entire evaporation process occurs at moderate temperatures $\left(100-120^{\circ} \mathrm{F}\right)$.

Figure 2-2 shows the details of the evaporator vessel location with respect to the primary condenser, reboiler, and recirculation pump. The evaporator vessel is about 27 feet tall with a nominal inside diameter of 17". The bottom 12 feet of the vessel is stainless steel and the top 15 feet is acrylic. The boiling surface will be maintained in the lower part of the acrylic section. The minimum and maximum liquid levels in the acrylic section are 5" and 40", respectively. The designed capacity of evaporator vessel and the recirculation piping is about 100 gallons. Feed tank supplies the simulant to the evaporator. The evaporator is designed to evaporate $0.4 \mathrm{gpm}$ of water.

The water vapor is condensed in the primary condenser. Under steady conditions, the concentrate is removed from the recirculation line and collected in the concentrate tank (Figure 2-1). The condensate from the primary condenser is collected in the primary condensate tank. A two-stage steam-driven jet pump maintains desired vacuum in the evaporator vessel. The jet pump has its own set of condensers, an inter and after condenser. A separate tank catches the condensate from the jet pump. The system can be operated under either a batch mode or a continuous (reflux) mode. Several sample and injection ports are provided to draw samples and inject tracers as needed. Key equipment in each sub-system is listed in Table 2-2.

\subsection{TEST OPERATING CONDITIONS}

The Pilot-Scale Evaporator can be operated under batch mode or recirculation mode as described in this section.

\subsubsection{Batch Mode of Operation}

In the batch mode, fresh feed is supplied to the evaporator and the condensate is removed from the evaporator. The evaporator inventory (approx. 100 gallons) keeps on concentrating due to evaporation. Once the target concentration is reached in the evaporator vessel, the concentrate is continuously removed from it to maintain a nominal level in the evaporator vessel. The first phase at the beginning of a particular campaign is then initial concentration phase, followed by the steady operation phase. During the later phase, fresh feed is supplied and concentrate and condensate are removed on a steady basis. At a nominal boil-off rate of $0.4 \mathrm{gpm}$, about 200 gallons of primary condensate is collected in an $8 \mathrm{hr}$-per-day operation. Thus several hundred gallons of fresh feed is needed every day to operated under this mode of operation. 
WSRC-TR-2003-00561, REVISION 0

SRT-RPP-2003-00244, REVISION 0

Table 2-2. Equipment Designation

\begin{tabular}{|c|c|}
\hline CL-BVI & BALL VALVE 1/e" SPEARS 23ट9-015C \\
\hline CL-BV2 & BALL VALVE $Z_{2}{ }^{*}$ WHITEY SS-45S8 \\
\hline $\mathrm{CL}-\mathrm{B} \vee 3$ & BALL VALVE $1^{\circ}$ SPEARS $2329-0100$ \\
\hline CL-BV4 & BALL VALVE $3 / 4^{x}$ SPEARS $2329-007 \mathrm{C}$ \\
\hline CL-BV5 & BALL VALVE $3 / 4^{*}$ SPEARS $2329-0070$ \\
\hline CL-BVG & BALL VALVE $3 / 4^{*}$ SPEARS $2329-007 C$ \\
\hline CL-BV7 & BALL VALVE I/4" SWAGELDK SS-43-S4 \\
\hline CL-BV8 & BALL VALVE $3 / 4^{*}$ SPEARS 2329 -007C \\
\hline CL-BV9 & BALL VALVE $3 / 4$ " SPEARS $2329-007 \mathrm{C}$ \\
\hline GL-BVIO & BALL VALVE $3 / 4^{*}$ SPEARS $2329-007 \mathrm{C}$ \\
\hline CL-BVI1 & BALL VALVE $3 / 4$ " SPEARS 2329-007C \\
\hline CL-BVI? & \%/" PLUG VA_VE PARKER \#18HB \\
\hline $\mathrm{CL}-\mathrm{BV} 13$ & $3 / 8$ PLUG VA_VE PARKER \#18HB \\
\hline CL-FT1 & MAGNETIC, FL DWVETER TR-370,3 \\
\hline CL-PU1 & PUMP 3/4 HP TEEL MDDEL H:P701B \\
\hline CL-PU: & PUMP /c HP TEEL VIDELL \#IP799B \\
\hline CL-TV1 & THRDTTLE VALVE 1/4 WHITEY SS-IVS4 \\
\hline & DESCRIPTIIN \\
\hline
\end{tabular}

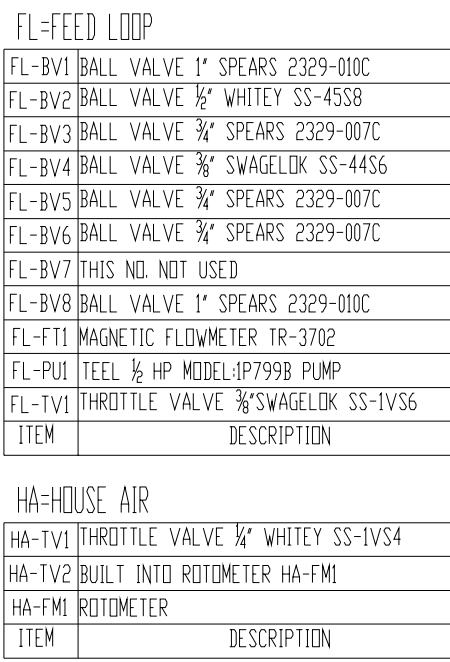

\begin{tabular}{|c|c|}
\hline ER-API & RLSEMINT PRESSURE TRANSDUCER TR-3718 \\
\hline ER-APD & RISEMINT PRESSURE TRANSDUCER TR-3717 \\
\hline ER-BVI & BALL VALVE $2 / 2^{\circ}$ SPEARS 2322-025C \\
\hline ER-BV2 & BALL VALVE 2" SPEARS $2329-020 \mathrm{C}$ \\
\hline ER-BV3 & BALL VALVE 1/:" SPEARS 2329-015C \\
\hline ER-BV4 & BALL VALVE 2/2" SPEARS 2322-025C \\
\hline ER-BV5 & BALL VALVE 14" SWAGELLKK SS-43S4 \\
\hline ER-BV6 & BALL VALVE Y/4" SWAGELDK SS-43S4 \\
\hline ER-BV7 & BALL VALVE Y4" SWAGELITK SS-43S4 \\
\hline ER-BV8 & BALL VALVE Y4" SWAGELDK SS-43S4 \\
\hline ER-BVG & BALL VALVE Y/4" SWAGELDK SS-43SA \\
\hline ER-BVIO & BALL VALVE 14" SWAGEL IIK SS-43S4 \\
\hline ER-BVI1 & BALL VALVE Y/4" SWAGELIKK SS-43S4 \\
\hline ER-BV12 & BALL VALVE Y/4" SWAGELDK SS-43S4 \\
\hline ER-BV13 & BALL VALVE y $_{4}$ "SWAGELLIK SS-43SA \\
\hline ER-BV14 & BALL VALVE 14" SWAGELDK SS-43S4 \\
\hline ER-BV15 & BALL VALVE $7_{4}$ SWAGELIIK SS-43S4 \\
\hline ER-BV16 & BALL VALVE YA" SWAGELITK SS-43S4 \\
\hline ER-BV17 & BALL VALVE Y/4" SWAGELIKK SS-43S4 \\
\hline ER-DP1 & RISEMINT PRESSURE TRANSDUCER TR-2150 \\
\hline ER-DP? & RISEMINT PRESSURE TRANSDUCER TR-3720 \\
\hline ER-DP3 & RLSEMINT PRESSURE TRANSDUCER TR-3554 \\
\hline ER-FMI & RDTIMETER \\
\hline ER-FTI & MAGNETIC FLDWNETER TR-3278 \\
\hline ER-PGI & PRESSURE GUAGE \\
\hline ER-PTI & RLSEMINT PRESSLRE TRANSDUCER TR-3554 \\
\hline ER-PU1 & PUMP 3 HP TEEL MLDEL \#2P392 \\
\hline ER-SII & SAMPLE/INJECTIIN PIRT //4 SWACELIK SS 42SS \\
\hline ER-TCI & "E*" TYPE THERNICGUPLE TR-1520 \\
\hline ER-TCE & "EE" TYPE THERMLCDUPLE TR-1523 \\
\hline ER-TC,3 & "Ex" TYPE THERVICIUPLE TR-1525 \\
\hline ER-TCA & "E" TYPE THERVICLUPLE TR-1505 \\
\hline ER-TV1 & I" GLIBE VALVE MCMASTER CARR \#4889K15 \\
\hline ITFM & DESCRIPTIIN \\
\hline
\end{tabular}

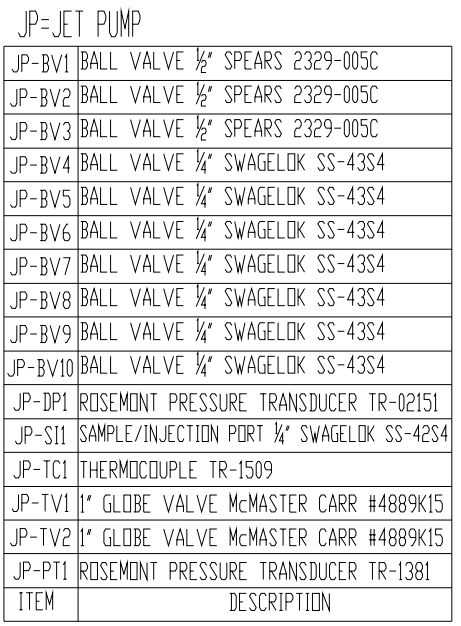

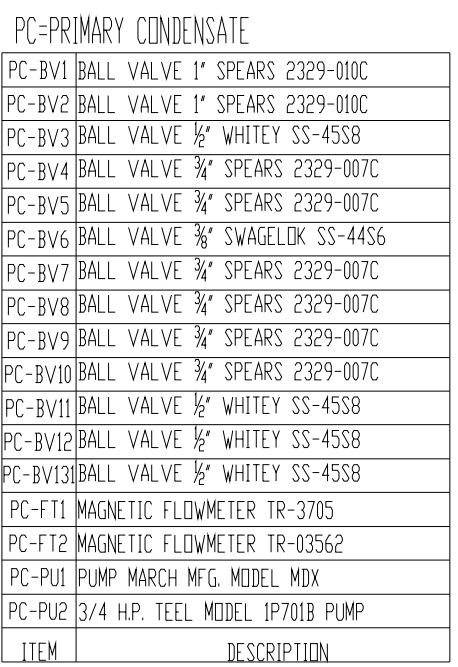

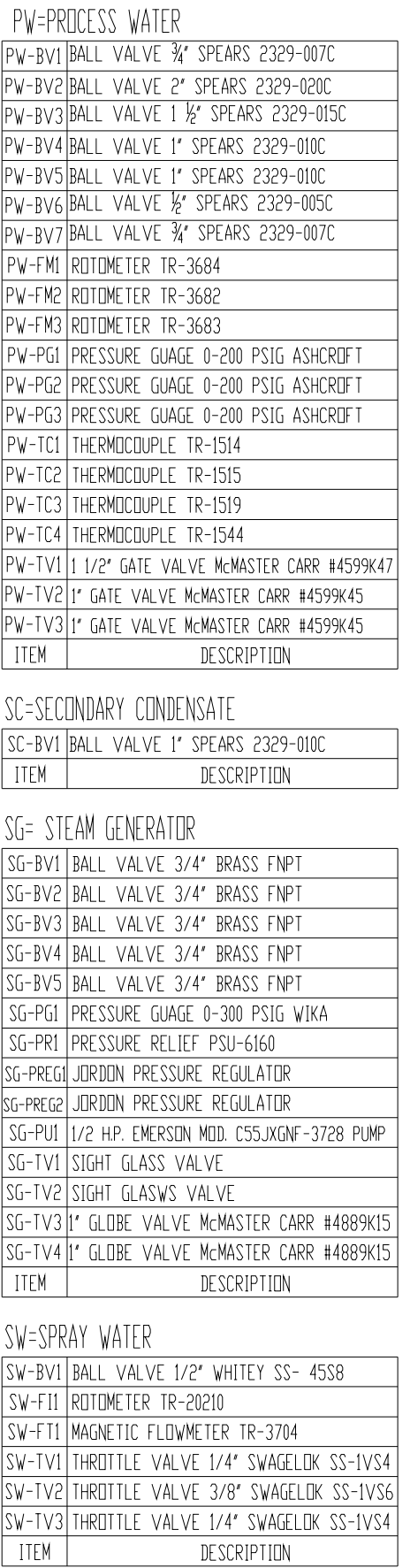


WSRC-TR-2003-00561, REVISION 0

SRT-RPP-2003-00244, REVISION 0

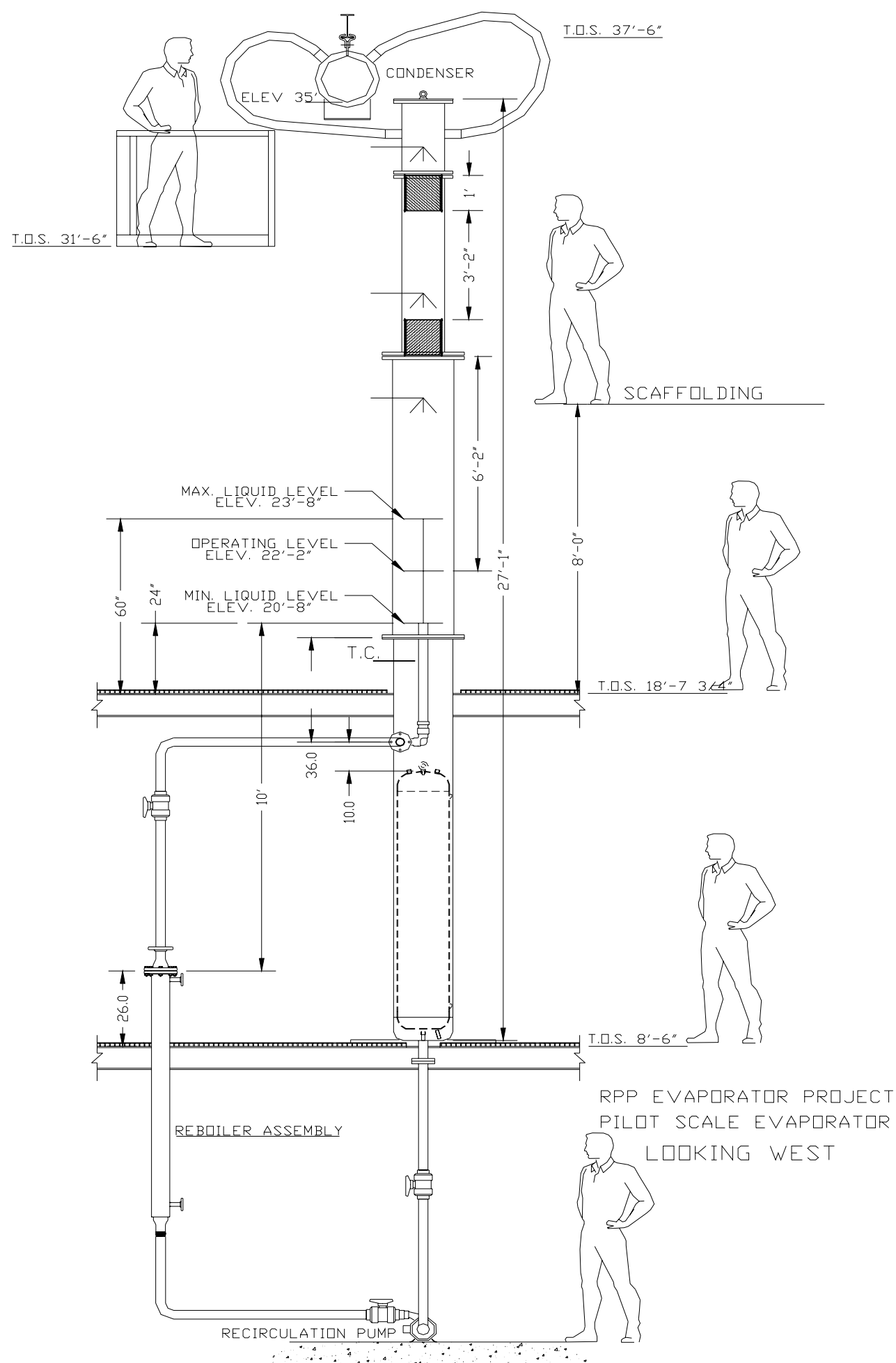

Figure 2-2. Pilot-Scale Evaporator Elevations Details 


\subsubsection{Recirculation Mode of Operation}

In this mode the initial concentration phase is the same as described above. Once fresh feed runs out, the concentrate and the primary condensate stream are combined in the feed tank to reconstitute feed. The liquid levels in the evaporator vessel, feed tank, and the condensate tank are kept at a constant level to assure that the recycled feed is representative of the fresh feed. Thus, the recycled feed never runs out and the evaporator can be operated for longterm tests without having thousands of gallons of fresh feed.

\subsection{EVAPORATOR CAMPAIGNS}

Three evaporation campaigns were completed under this test program as described in this section. The Pilot-Scale startup and operation followed EDL Work Instructions I-EDL-0151, SRT-RPP-2003-00078, 6-11-2003.

\subsubsection{Evaporator Operation}

All the desired feed simulants were first transferred from mixing vessels/drums to the feed tank. The feed was agitated on a continuous basis to preclude any settling. Using the main feed pump and 3/4" transfer line, the evaporator vessel was filled with fresh feed up to the nominal operating level ( 100 gallons). The evaporator was then started in the following sequence.

1. Start steam generator.

2. Ensure adequate cooling water to the primary condenser and the two jet pump condensers.

3. Start two-stage jet pump (second stage is started first) to start pulling the vacuum on the system.

4. Start the main recirculation pump to establish recirculation rates of $90-100$ gpm.

5. Start supplying steam to the reboiler.

6. Once the concentrate starts boiling, adjust the reboiler heat input, feed rate, concentrate removal rate and system pressure. The system pressure was adjusted to 1 psia by varying the air bleed on the suction side of the first stage of the jet pump. Steam supply rate to the reboiler was adjusted to maintain the cold side temperature rise around $2.7^{\circ} \mathrm{C}$. At $90 \mathrm{gpm}$ recirculation rate this translates to energy required to boil-off $0.4 \mathrm{gpm}$ of water.

7. Pull desired samples from the sample ports as needed.

8. Inject antifoam agent through the recirculation loop injection port as needed. 


\subsubsection{Sampling Methods}

The Pilot-Scale Evaporator System was designed with several sample/injection ports to draw samples or to inject spiking material as needed. Throughout the test program, a large number of samples were collected and archived. The idea was to select a small subset of these samples for analyses as needed. The liquid samples were drawn for two separate analytical labs. Most of the liquid samples were drawn for archival and analyses by SRTC's analytical labs. A small set of liquid and all offgas samples were drawn for the regulatory analyses by offsite vendors. SRTC contracted BWXT to perform regulatory analyses of liquid samples. Air Tech. performed offgas sampling and analyses for regulatory purposes.

Note that the entire system is designed to operate under vacuum. The vapor space in nominally kept at 1 psia. The boiling surface was nominally $20 \mathrm{ft}$ above the main circulation pump. Thus with the hydrostatic head of $20 \mathrm{ft}$ of concentrate (at $88.4 \mathrm{lbm} / \mathrm{ft} 3$ ), the pump inlet pressure is 13.3 psia. For water, the pump inlet pressure is 9.7 psia. The sample port for the concentrate is located downstream of the pump. The pump outlet pressure is the function of the system pressure loss that varies depending upon the rheology of the working fluid.

For water runs, pressure throughout the circulation loop remained below atmospheric pressure. For the simulant runs, the pressure at the sample port was slightly negative (below atmospheric) at the beginning of the concentration period. As the concentrate in the evaporator vessel became denser, the sample port pressure became positive. In view of these considerations, sometimes the sample was sucked out using a syringe and then transferred to a vial. For most of the time the sample port pressure was positive and the sample was collected in a vial/bottle by opening the sample port valve.

The feed sample port was always under positive pressure and the samples were collected in a vial/bottle. Both the feed sample port and the concentrate sample port were allowed to run for at least 10 volumes of the dead space in the sample lines. After this flush-out the samples were collected. Typically $60-\mathrm{ml}$ samples were collected for all liquid streams. For the concentrate, a small amount $(\sim 15-20 \mathrm{ml})$ was filtered through a filter paper to collect insoluble solids. The filtrate was then filtered again through another filter paper to prepare blanks. Both filter papers were dried in a desiccator. The blanks provided information above the solubles.

The primary and the secondary condensate samples were drawn from the respective tank dip tubes using a syringe. The syringe was flushed out twice with the respective condensate before collecting the sample. The last liquid sample was the knockout pot drain loop (KDL) sample. The KDL sample amount was usually very small and at the end of each day of operation about 30-40 $\mathrm{ml}$ of sample was collected in a vial. Liquid samples for regulatory analyses were drawn from the same ports using the same techniques. However, the samples were drawn in 1-liter bottles.

The offgas sampling was performed by Air-Tech Environmental, LLC. Air-Tech followed the protocol of EPA Method 0010. Details of their setup and sampling procedure are documented in a separate report [9]. 


\subsubsection{Water Tests}

The first evaporation campaign used water as the working fluid. The purpose of this campaign was to shake down the test facility and identify any problems with the hardware or the operating conditions.

This campaign turned out to be very useful in identifying a major shortcoming in the recirculation loop configuration. In the initial design used for the Pilot-Scale evaporator, the concentrate enters the evaporator vessel tangentially at about $4 \mathrm{ft}$ below the boiling surface. This configuration had two shortcomings - a swirling motion due to tangential entry at about $8 \mathrm{ft} / \mathrm{s}$ and poor mixing due to excessive submergence of $4 \mathrm{ft}$. The result was large temperature fluctuations in the boiling region and unstable boiling operation. Due to poor vertical mixing, large chunks of supersaturated water would flash violently causing excessive vapor generation thus overwhelming the steam jet pump. The pump was designed to handle nominal evaporation rate of $0.4 \mathrm{gpm}$ with minor fluctuations.

Since the saturation temperature follows the system pressure, large-scale oscillations in evaporator temperature and pressure were observed. Consequently, the concentrate return line was reconfigured to allow the returning fluid jet in a vertical direction. The jet was discharged at about $1 \mathrm{ft}$ below and up towards the boiling surface at a fluid velocity of about $2 \mathrm{ft} / \mathrm{s}$ (Figure 2-2). This modification resulted in a well-mixed boiling region and stable operation. All subsequent testing was done with the modified configuration.

\subsubsection{Test 1- Simulated Ultrafiltration Recycles with HLW SBS from Duratek}

Test 1 was performed using Ultrafiltration Recycles Simulant with HLW SBS in the following quantities.

\section{Simulant}

First Wash (see Appendix A for recipe)

Second Wash (see Appendix B for recipe)

Leach (see Appendix $\mathrm{C}$ for recipe)

Acid Cleaning Solution (see Appendix D for recipe)

Caustic Solution (0.1 Molar $\mathrm{NaOH})$

HLW SBS from Duratek

\author{
Volume (Liters) \\ 448.4 \\ 448.4 \\ 62.32 \\ 335.92 \\ 224.96 \\ 1520.00
}

Total 3040 liters (803 gallons)

The simulant quantities (except for HLW SBS) were prepared in Engineering Development Lab of SRTC according to the procedure: WTP Pilot Scale Evaporator Mixing Procedure, EES Field Procedure FP-955, 5-29-03.

Table 2-3 gives a chronology of events for Test 1. Note that the Pilot-Scale Evaporator was not operated round the clock. Instead it was normally started in the morning and shut down at the end of the working day. No runs were made over the weekends. Thus the actual elapsed time for the chemicals in the evaporator was much larger than the actual run time. 
WSRC-TR-2003-00561, REVISION 0

SRT-RPP-2003-00244, REVISION 0

Table 2-3. Evaporator Test 1 Chronology

\begin{tabular}{|c|c|c|c|c|c|c|c|}
\hline Date & Day & Time & $\begin{array}{l}\text { Daily Boil } \\
\text { Time } \\
\text { hrs:min }\end{array}$ & $\begin{array}{l}\text { Comm Boil } \\
\text { Time } \\
\text { hrs:min }\end{array}$ & $\begin{array}{l}\text { Event } \\
\text { Time } \\
\text { hrs:min }\end{array}$ & $\begin{array}{l}\text { Sp. } \\
\text { Gr. }\end{array}$ & Event \\
\hline \multirow[t]{5}{*}{$6 / 11 / 03$} & Wed & 13:00 & & & 13:00 & & System Started, Pulled Feed Samples \\
\hline & & $14: 00$ & & & $13: 00$ & & Heat added to reboiler \\
\hline & & $15: 00$ & & & & & \\
\hline & & $16: 00$ & & & & & \\
\hline & & $17: 00$ & 4:00 & 4:00:00 & $17: 00$ & & $\begin{array}{l}\text { Pulled samples Feed, CT, PCT, SCT Shut } \\
\text { Down }\end{array}$ \\
\hline \multirow[t]{11}{*}{$6 / 12 / 03$} & Thur & $7: 00$ & & & $7: 15$ & & System Started \\
\hline & & $8: 00$ & & & & & \\
\hline & & 9:00 & & & & & \\
\hline & & $10: 00$ & & & $10: 35$ & & Pulled Feed Sample \\
\hline & & $11: 00$ & & & & & \\
\hline & & $12: 00$ & & & $12: 00$ & & Pulled samples Feed, CT, PCT, SCT \\
\hline & & 13:00 & & & & & \\
\hline & & $14: 00$ & & & $14: 18$ & 1.095 & Sp Gr by Process Inst. 1.0916 \\
\hline & & $15: 00$ & & & $15: 23$ & 1.107 & \\
\hline & & $16: 00$ & & & $16: 00$ & 1.118 & Pulled samples Feed, CT, PCT, SCT, KDL \\
\hline & & $17: 00$ & $10: 00$ & 14:00:00 & $17: 15$ & & Shut Down \\
\hline \multirow[t]{4}{*}{$6 / 16 / 03$} & Mon & $7: 00$ & & & $7: 30$ & & System Started \\
\hline & & $8: 00$ & & & $8: 05$ & & Added heat to reboiler \\
\hline & & $9: 00$ & & & $9: 45$ & & Pulled Feed Sample \\
\hline & & $10: 00$ & 3:05 & 17:05:00 & $10: 35$ & & $\begin{array}{l}\text { System shut down for replacement of } 3 " \text { flex } \\
\text { tubes to primary condenser }\end{array}$ \\
\hline \multirow[t]{6}{*}{$6 / 18 / 03$} & Wed & $12: 00$ & & & $12: 00$ & & Flex tubes installed \\
\hline & & $13: 00$ & & & $13: 30$ & 1.138 & Heat added to reboiler after starting the system \\
\hline & & $14: 00$ & & & & & \\
\hline & & $15: 00$ & & & $15: 23$ & 1.107 & \\
\hline & & $15: 00$ & & & & & \\
\hline & & $16: 00$ & $3: 00$ & 20:05:00 & $16: 30$ & & System shut down \\
\hline \multirow[t]{9}{*}{$6 / 19 / 03$} & Thur & $8: 00$ & & & $8: 35$ & & System started \\
\hline & & 9:00 & & & & & \\
\hline & & $10: 00$ & & & & & \\
\hline & & $11: 00$ & & & & & \\
\hline & & $12: 00$ & & & & & \\
\hline & & $13: 00$ & & & & & \\
\hline & & $14: 00$ & & & $14: 00$ & & Pulled sample SCT \\
\hline & & $15: 00$ & & & & & \\
\hline & & $16: 00$ & $7: 35$ & $27: 40: 00$ & $16: 10$ & 1.218 & System shut down \\
\hline \multirow[t]{6}{*}{$6 / 20 / 03$} & Fri & $9: 00$ & & & $9: 30$ & & Added 6 gal of feed to achieve mid level \\
\hline & & $10: 00$ & & & $10: 00$ & 1.204 & System started \\
\hline & & $11: 00$ & & & & & \\
\hline & & $12: 00$ & & & & & \\
\hline & & $13: 00$ & & & & & \\
\hline & & $14: 00$ & $4: 55$ & $32: 35: 00$ & $14: 55$ & 1.216 & System shut down \\
\hline \multirow[t]{6}{*}{$6 / 23 / 03$} & Mon & $8: 00$ & & & $8: 45$ & & System started \\
\hline & & 9:00 & & & & & \\
\hline & & $10: 00$ & & & & & \\
\hline & & $11: 00$ & & & 11:04 & & $\begin{array}{l}\text { Performed addition of antifoam test @ } 500 . \\
1000,1400 \mathrm{ppm}\end{array}$ \\
\hline & & $12: 00$ & & & & & \\
\hline & & $13: 00$ & & & $13: 15$ & & $\begin{array}{l}\text { The concentrate and recirculation pumps } \\
\text { developed leaks, System shut down }\end{array}$ \\
\hline \multirow[t]{3}{*}{$6 / 24 / 03$} & Tue & $14: 00$ & & & $14: 35$ & & $\begin{array}{l}\text { System started again after rebuilding } \\
\text { concentrate and recirculation pumps }\end{array}$ \\
\hline & & $15: 00$ & & & & & \\
\hline & & 16:00 & $7: 45$ & 40:20:00 & $16: 30$ & & System shut down \\
\hline
\end{tabular}


WSRC-TR-2003-00561, REVISION 0

SRT-RPP-2003-00244, REVISION 0

Table 2-3. Evaporator Test 1 Chronology - continued

\begin{tabular}{|c|c|c|c|c|c|c|c|}
\hline Date & Day & Time & $\begin{array}{c}\text { Daily Boil } \\
\text { Time } \\
\text { hrs:min }\end{array}$ & $\begin{array}{c}\text { Comm } \\
\text { Boil Time } \\
\text { hrs:min }\end{array}$ & $\begin{array}{c}\text { Event } \\
\text { Time } \\
\text { hrs:min }\end{array}$ & $\begin{array}{l}\text { Sp. } \\
\text { Gr. }\end{array}$ & Event \\
\hline \multirow[t]{10}{*}{$6 / 25 / 03$} & Wed & $7: 00$ & & & $7: 15$ & & System started \\
\hline & & $8: 00$ & & & & & \\
\hline & & 9:00 & & & $9: 30$ & & Pulled samples Feed, CT, PCT, SCT \\
\hline & & $10: 00$ & & & & & \\
\hline & & $11: 00$ & & & & & \\
\hline & & $12: 00$ & & & & & \\
\hline & & $13: 00$ & & & & & \\
\hline & & $14: 00$ & & & & & \\
\hline & & $15: 00$ & & & $15: 50$ & & Pulled samples Feed, CT, PCT, SCT \\
\hline & & $16: 00$ & $9: 00$ & 49:20:00 & $16: 15$ & & System shut down \\
\hline \multirow[t]{10}{*}{$6 / 26 / 03$} & Thur & $7: 00$ & & & $7: 15$ & & System started \\
\hline & & $8: 00$ & & & $8: 00$ & & Pulled samples Feed, CT, PCT, SCT \\
\hline & & 9:00 & & & & & \\
\hline & & $10: 00$ & & & & & \\
\hline & & $11: 00$ & & & & & \\
\hline & & $12: 00$ & & & $12: 55$ & 1.211 & \\
\hline & & 13:00 & & & & & \\
\hline & & $14: 00$ & & & $14: 25$ & & Sp. Gr. Of concentrate filtrate $=1.21$ \\
\hline & & $15: 00$ & & & $15: 50$ & & Pulled samples Feed, CT, PCT, SCT \\
\hline & & $16: 00$ & 9:00 & 58:20:00 & $16: 15$ & & System shut down \\
\hline \multirow[t]{4}{*}{$6 / 27 / 03$} & Fri & $7: 00$ & & & $7: 20$ & & System started \\
\hline & & $8: 00$ & & & & & \\
\hline & & 9:00 & & & $9: 15$ & & Pulled samples Feed, CT, PCT, SCT \\
\hline & & $10: 00$ & $3: 25$ & $61: 45: 00$ & $10: 45$ & & System shut down \\
\hline \multirow[t]{9}{*}{$6 / 30 / 03$} & Mon & $8: 00$ & & & $8: 35$ & & System started \\
\hline & & 9:00 & & & & & \\
\hline & & $10: 00$ & & & $10: 30$ & 1.216 & Pulled samples Feed, CT, PCT, SCT \\
\hline & & $11: 00$ & & & & & \\
\hline & & $12: 00$ & & & & & \\
\hline & & 13:00 & & & & & \\
\hline & & $14: 00$ & & & & & \\
\hline & & $15: 00$ & & & $15: 00$ & & Pulled samples Feed, CT, PCT, SCT \\
\hline & & $16: 00$ & $6: 40$ & $68: 25: 00$ & $15: 15$ & & System shut down \\
\hline \multirow[t]{6}{*}{$7 / 1 / 03$} & Tue & $10: 00$ & & & $10: 45$ & & System started \\
\hline & & $11: 00$ & & & & & \\
\hline & & $12: 00$ & & & & & \\
\hline & & 13:00 & & & & & \\
\hline & & $14: 00$ & & & $14: 00$ & & $\begin{array}{l}\text { Pulled samples Feed, CT, PCT, SCT, } 0.4 \mathrm{cfm} \\
\text { air bleed to evap. }\end{array}$ \\
\hline & & $15: 00$ & $4: 50$ & $73: 15: 00$ & $15: 35$ & & System shut down \\
\hline \multirow[t]{8}{*}{$7 / 2 / 03$} & Wed & $8: 00$ & & & $8: 00$ & & System started \\
\hline & & 9:00 & & & $9: 35$ & & Pulled samples Feed, CT \\
\hline & & $10: 00$ & & & & & \\
\hline & & $11: 00$ & & & & & \\
\hline & & $12: 00$ & & & & & \\
\hline & & 13:00 & & & & & \\
\hline & & $14: 00$ & & & $14: 00$ & & Pulled samples Feed, CT, PCT, SCT \\
\hline & & 15:00 & $6: 30$ & 79:45:00 & $14: 30$ & & System shut down \\
\hline \multirow[t]{6}{*}{$7 / 9 / 03$} & Wed & $12: 00$ & & & $12: 00$ & & System started, $0.2 \mathrm{cfm}$ air bleed to evap. \\
\hline & & 13:00 & & & $12: 30$ & & Pulled Feed samples \\
\hline & & $14: 00$ & & & & & \\
\hline & & $15: 00$ & & & & & \\
\hline & & $16: 00$ & & & $16: 40$ & & Pulled CT, PCT, SCT and KDL samples \\
\hline & & $17: 00$ & $5: 00$ & $84: 45: 00$ & $17: 00$ & & System shut down \\
\hline
\end{tabular}




\subsubsection{Test 2 - Treated AN102 \& Envelope C LAW SBS from Duratek}

Test 2 was performed using Treated AN-102 R2 Filtrate with LAW SBS in the following quantities.

\begin{tabular}{|c|c|}
\hline Simulant & Volume (Liters) \\
\hline Treated AN102R2 Filtrate & 1575 \\
\hline LAW SBS from Duratek & 1575 \\
\hline & 3150 liters (830 gallons) \\
\hline
\end{tabular}

Table 3.4 gives a chronology of events for Test 2. As noted on Table 3.4, Test 2 had the following three distinct phases of operations.

- Initial Concentration Phase. In this phase fresh feed was boiled off in the evaporator without removing any concentrate. The fresh feed had a specific gravity of 1.145 . The target concentrate Sp. Gr. was 1.43 ( $88.44 \mathrm{lbm} / \mathrm{ft} 3$ density at $111 \mathrm{~F})$. Of the total feed inventory of 830 gallons, this phase used about 345 gallons to yield 100 gallons of concentrate in the evaporator vessel.

- Steady Operation with Fresh Feed. In this phase another 345 gallons of fresh feed was fed to the evaporator and 100 gallons of concentrate was removed.

- Long Term Test with Recycled Feed. For this phase of testing, the concentrate and the primary condensate were transferred back to the feed tank to reconstitute the feed. 
WSRC-TR-2003-00561, REVISION 0 SRT-RPP-2003-00244, REVISION 0

Table 2-4. Evaporator Test 2 Chronology

\begin{tabular}{|c|c|c|c|c|c|}
\hline Date & $\begin{array}{l}\text { Event Time } \\
\text { hrs:min }\end{array}$ & $\begin{array}{c}\text { Daily Boil } \\
\text { Time } \\
\text { hrs:min }\end{array}$ & $\begin{array}{c}\text { Comm Boil } \\
\text { Time } \\
\text { hrs:min }\end{array}$ & $\begin{array}{l}\text { Density } \\
\text { lbm/ft3 }\end{array}$ & Event \\
\hline \multicolumn{6}{|c|}{ Initial Concentration Starts } \\
\hline $9 / 15 / 03$ & $10: 45$ & & & & $\begin{array}{l}\text { Started filling up the evaporator vessel with feed from } \\
\text { feed tank }\end{array}$ \\
\hline \multirow[t]{5}{*}{ Mon } & $11: 15$ & & & 71.5 & $\begin{array}{l}100 \text { gallons of feed transferred from feed tank to evap } \\
\text { vessel }\end{array}$ \\
\hline & 15:00 & & & & Started steam generator \\
\hline & $15: 30$ & & & & Started jet pump and reboiler \\
\hline & $16: 15$ & & & 71.92 & Vigorous boiling, froth height $\sim 4 \mathrm{ft}$ \\
\hline & $17: 30$ & & & 74.84 & \\
\hline $9 / 16 / 03$ & $7: 50$ & & & & Started jet pump and reboiler \\
\hline \multirow[t]{4}{*}{ Tue } & $9: 10$ & & & & Steam generator pressure dropped, shut down \\
\hline & $9: 40$ & & & & Checked steam generator fuses, system started again \\
\hline & 11:00 & & & & Pulled Feed, CT, PCT \& SCT Samples \\
\hline & $14: 38$ & & & 88.4 & $\begin{array}{l}\text { Reached target concentration, Pulled Feed, CT, PCT, } \\
\text { SCT \& KDL Samples, System shut down }\end{array}$ \\
\hline \multicolumn{6}{|c|}{ Steady Operation with Fresh Feed } \\
\hline $9 / 17 / 03$ & $9: 15$ & & & 88.25 & Started steam generator \\
\hline \multirow[t]{10}{*}{ Wed } & $9: 45$ & & & & Boiling started. Combined 54 spiking ampules \\
\hline & $10: 49$ & & & & $\begin{array}{l}\text { Injected } 56 \text { grams of antifoam to the evap recirculation } \\
\text { loop }(100 \mathrm{ppm})\end{array}$ \\
\hline & $10: 56$ & & & & $\begin{array}{l}\text { Injected } 56 \text { grams of more antifoam to the evap } \\
\text { recirculation loop (total } 200 \mathrm{ppm} \text { ) }\end{array}$ \\
\hline & 12:00 & & & & Pulled Feed, CT, PCT \& SCT Samples \\
\hline & $13: 15$ & & & & Pulled baseline samples for regulatory analyses \\
\hline & 13:18 & & & & Began addition of $540 \mathrm{~mL}$ of organic spike \\
\hline & $14: 10$ & & & & $\begin{array}{l}\text { Pulled Feed, CT, PCT \& SCT Samples, Also pulled all } \\
\text { regulatory liquid samples }\end{array}$ \\
\hline & 15:05 & & & & Pulled Feed, CT, PCT \& SCT Samples \\
\hline & 16:05 & & & & Pulled Feed, CT, PCT, SCT and KDL samples for ADS \\
\hline & $17: 20$ & $7: 35$ & $7: 35$ & & System shut down \\
\hline $9 / 18 / 03$ & $9: 45$ & & & & Concentrate pump leaky seal was replaced \\
\hline \multirow[t]{7}{*}{ Thu } & 10:05 & & & & Started jet pump and reboiler \\
\hline & $10: 20$ & & & & Boiling started \\
\hline & 11:00 & & & & Pulled Feed, CT, PCT \& SCT Samples \\
\hline & 12:00 & & & & Pulled Feed, CT, PCT \& SCT Samples \\
\hline & 13:00 & & & & Pulled Feed, CT, PCT \& SCT Samples \\
\hline & 14:00 & & & & Pulled Feed, CT, PCT \& SCT Samples \\
\hline & $14: 15$ & $3: 55$ & $11: 30$ & & System shut down \\
\hline $9 / 25 / 03$ & $9: 55$ & & & & Started steam generator \\
\hline Thu & 10:00 & & & & Started jet pump and reboiler \\
\hline \multicolumn{6}{|c|}{ Start of Long-Term Test with Recycled Feed } \\
\hline & $10: 50$ & & & & $\begin{array}{l}\text { Concentrate and primary condensate were combined in } \\
\text { the feed tank }\end{array}$ \\
\hline & 13:00 & & & & Pulled Feed, CT, PCT \& SCT Samples \\
\hline & $15: 52$ & & & & $\begin{array}{l}\text { Injected } 56 \text { grams of more antifoam to the evap } \\
\text { recirculation loop (total } 300 \mathrm{ppm} \text { ) }\end{array}$ \\
\hline & $16: 50$ & & & & Pulled Feed, CT, PCT, SCT \& KDL Samples \\
\hline & 17:00 & $6: 10$ & $17: 40$ & & System shut down \\
\hline $9 / 26 / 03$ & $10: 10$ & & & & Steam generator started \\
\hline \multirow[t]{5}{*}{ Fri } & 10:18 & & & & Started jet pump and reboiler \\
\hline & $10: 40$ & & & & Boiling vigorously \\
\hline & $11: 15$ & & & & Pulled Feed, CT, PCT \& SCT Samples \\
\hline & $15: 50$ & & & & Pulled Feed, CT, PCT \& SCT Samples \\
\hline & $16: 05$ & $5: 25$ & $23: 05$ & & $\begin{array}{l}\text { System shut down. Noticed a scale in the clear section } \\
\text { of evap. Vessel upto } 20 \text { " level }\end{array}$ \\
\hline
\end{tabular}


WSRC-TR-2003-00561, REVISION 0 SRT-RPP-2003-00244, REVISION 0

Table 2-4. Evaporator Test 2 Chronology - continued

\begin{tabular}{|c|c|c|c|c|c|}
\hline Date & $\begin{array}{l}\text { Event Time } \\
\text { hrs:min }\end{array}$ & $\begin{array}{c}\text { Daily Boil } \\
\text { Time } \\
\text { hrs:min }\end{array}$ & $\begin{array}{c}\text { Comm Boil } \\
\text { Time } \\
\text { hrs:min }\end{array}$ & $\begin{array}{l}\text { Density } \\
\text { lbm/ft3 }\end{array}$ & Event \\
\hline \multicolumn{6}{|c|}{ Start of Long-Term Test with Recycled Feed - continued } \\
\hline $9 / 30 / 03$ & 13:00 & & & & Steam generator started \\
\hline \multirow[t]{5}{*}{ Tue } & $13: 10$ & & & & Started jet pump and reboiler \\
\hline & $13: 30$ & & & & Pulled Feed, CT, PCT \& SCT Samples \\
\hline & $13: 35$ & & & & Boiling started \\
\hline & $16: 50$ & & & & Pulled Feed, CT, PCT \& SCT Samples \\
\hline & $16: 55$ & $3: 20$ & $26: 25$ & & System shut down \\
\hline $10 / 1 / 03$ & $8: 10$ & & & & Started steam generator \\
\hline \multirow[t]{6}{*}{ Wed } & $8: 15$ & & & & Started jet pump and reboiler \\
\hline & $8: 35$ & & & & Boiling started \\
\hline & $8: 50$ & & & & System shut down, concentrate pump leaking \\
\hline & $10: 30$ & & & & $\begin{array}{l}\text { Started the system again after installing a new seal for } \\
\text { concentrate pump }\end{array}$ \\
\hline & 11:00 & & & & Pulled Feed, CT, PCT \& SCT Samples \\
\hline & $11: 30$ & $1: 00$ & $27: 25$ & & System shut down \\
\hline $10 / 6 / 03$ & 13:00 & & & & Started steam generator \\
\hline \multirow[t]{4}{*}{ Mon } & $13: 20$ & & & & Started jet pump and reboiler \\
\hline & $13: 50$ & & & & Boiling started \\
\hline & $14: 50$ & & & & Concentrate line plugged \\
\hline & $15: 25$ & $1: 35$ & 29:00 & & System shut down \\
\hline $10 / 7 / 03$ & $9: 45$ & & & & Started steam generator, jet pump and reboiler \\
\hline \multirow[t]{4}{*}{ Tue } & 10:00 & & & & Boiling started \\
\hline & $11: 20$ & & & & Pulled Feed, CT, PCT \& SCT Samples \\
\hline & $16: 40$ & & & & Pulled Feed, CT, PCT, SCT \& KDL Samples \\
\hline & $16: 45$ & $6: 45$ & $35: 45$ & & System shut down \\
\hline $10 / 9 / 03$ & $9: 30$ & & & & Started steam generator, jet pump and reboiler \\
\hline \multirow[t]{6}{*}{ Thu } & 10:00 & & & & Boiling started \\
\hline & $10: 25$ & & & & Shut down, leakage in steam generator sight glass \\
\hline & $14: 00$ & & & & Leak fixed, system started again \\
\hline & $14: 20$ & & & & $\begin{array}{l}\text { Boiling started. Added } 100 \mathrm{ppm} \text { of antifoam added at } \\
15: 40(300 \mathrm{ppm} \text { total })\end{array}$ \\
\hline & $16: 40$ & & & & Pulled Feed, CT, PCT, SCT \& KDL Samples \\
\hline & $16: 55$ & 3:00 & $38: 45$ & 88.3 & System shut down \\
\hline $10 / 10 / 03$ & $10: 00$ & & & & Started steam generator \\
\hline \multirow[t]{4}{*}{ Fri } & 10:05 & & & & Started jet pump and reboiler \\
\hline & $10: 20$ & & & & Boiling started \\
\hline & $16: 00$ & & & & Pulled Feed, CT, PCT, SCT \& KDL Samples \\
\hline & $16: 05$ & $5: 15$ & 44:00 & & System shut down \\
\hline $10 / 13 / 03$ & $9: 30$ & & & & Started steam generator \\
\hline \multirow[t]{6}{*}{ Mon } & $9: 37$ & & & & Started jet pump and reboiler \\
\hline & $9: 55$ & & & & Boiling started \\
\hline & 10:00 & & & & Pulled Feed, CT, PCT \& SCT Samples \\
\hline & 15:00 & & & 89.6 & \\
\hline & $16: 40$ & & & & Pulled Feed, CT, PCT, SCT \& KDL Samples \\
\hline & $16: 45$ & $6: 50$ & $50: 50$ & & System shut down \\
\hline $10 / 14 / 03$ & $9: 15$ & & & & Started steam generator \\
\hline \multirow[t]{5}{*}{ Tue } & $9: 25$ & & & & Started jet pump and reboiler \\
\hline & $9: 39$ & & & & Boiling started \\
\hline & 10:00 & & & & Pulled Feed, CT, PCT \& SCT Samples \\
\hline & $16: 40$ & & & & Pulled Feed, CT, PCT, SCT \& KDL Samples \\
\hline & $16: 49$ & $7: 10$ & $58: 00$ & & System shut down \\
\hline $10 / 15 / 03$ & $7: 50$ & & & & Started steam generator \\
\hline \multirow[t]{3}{*}{ Wed } & $7: 55$ & & & & Started jet pump and reboiler \\
\hline & $8: 10$ & & & & Boiling started \\
\hline & $12: 45$ & $4: 35$ & $62: 35$ & & System sht down, concentrate pump leaking \\
\hline
\end{tabular}


WSRC-TR-2003-00561, REVISION 0 SRT-RPP-2003-00244, REVISION 0

Table 2-4. Evaporator Test 2 Chronology - continued

\begin{tabular}{|c|c|c|c|c|c|}
\hline Date & $\begin{array}{l}\text { Event Time } \\
\text { hrs:min }\end{array}$ & $\begin{array}{c}\text { Daily Boil } \\
\text { Time } \\
\text { hrs:min }\end{array}$ & $\begin{array}{c}\text { Comm Boil } \\
\text { Time } \\
\text { hrs:min }\end{array}$ & $\begin{array}{l}\text { Density } \\
\text { lbm/ft3 }\end{array}$ & Event \\
\hline \multicolumn{6}{|c|}{ Start of Long-Term Test with Recycled Feed - continued } \\
\hline $10 / 20 / 03$ & $10: 10$ & & & & Started steam generator \\
\hline \multirow[t]{4}{*}{ Mon } & $10: 15$ & & & & Started jet pump and reboiler \\
\hline & $10: 30$ & & & & Boiling started \\
\hline & $16: 50$ & & & & Pulled Feed, CT, PCT, SCT \& KDL Samples \\
\hline & 17:00 & $6: 30$ & 69:05 & & System shut down \\
\hline $10 / 21 / 03$ & $8: 20$ & & & & Started steam generator \\
\hline \multirow[t]{5}{*}{ Tue } & $9: 30$ & & & & Leakage in cooling water line, system shut down \\
\hline & $10: 00$ & & & & System started again \\
\hline & $10: 20$ & & & & Boiling started \\
\hline & $16: 50$ & & & & Pulled Feed, CT, PCT, SCT \& KDL Samples \\
\hline & 17:00 & $6: 40$ & $75: 45$ & & System shut down \\
\hline $10 / 22 / 03$ & $8: 00$ & & & & Started steam generator \\
\hline \multirow[t]{4}{*}{ Wed } & $8: 15$ & & & & Started jet pump and reboiler \\
\hline & $8: 30$ & & & & Boiling started \\
\hline & $16: 00$ & & & & Pulled Feed, CT, PCT, SCT \& KDL Samples \\
\hline & $16: 20$ & $7: 50$ & $83: 35$ & & System shut down \\
\hline $10 / 23 / 03$ & $9: 15$ & & & & Started steam generator \\
\hline \multirow[t]{3}{*}{ Thu } & $9: 20$ & & & & Started jet pump and reboiler \\
\hline & $9: 45$ & & & & Boiling started \\
\hline & $16: 45$ & $7: 00$ & $90: 35$ & & $\begin{array}{l}\text { Pulled Feed, CT, PCT, SCT \& KDL Samples, System } \\
\text { shut down }\end{array}$ \\
\hline $10 / 24 / 03$ & $8: 20$ & & & & Started steam generator \\
\hline \multirow[t]{4}{*}{ Fri } & $8: 30$ & & & & Started jet pump and reboiler \\
\hline & $8: 50$ & & & & Boiling started \\
\hline & $15: 45$ & & & & Pulled Feed, CT, PCT, SCT \& KDL Samples \\
\hline & $15: 50$ & $7: 00$ & $97: 35$ & & System shut down \\
\hline $10 / 27 / 03$ & $9: 55$ & & & & Started steam generator \\
\hline \multirow[t]{4}{*}{ Mon } & 10:00 & & & & Started jet pump and reboiler \\
\hline & $10: 15$ & & & & Boiling started \\
\hline & $13: 15$ & & & & Pulled Feed, CT, PCT, SCT \& KDL Samples \\
\hline & $14: 15$ & 4:00 & $101: 35$ & & System shut down \\
\hline $10 / 28 / 03$ & $8: 15$ & & & & Started steam generator \\
\hline \multirow[t]{6}{*}{ Tue } & $8: 20$ & & & & Started jet pump and reboiler \\
\hline & $8: 35$ & & & & Boiling started \\
\hline & 14:00 & & & & System shut down \\
\hline & $15: 50$ & & & & System started again, boiling started \\
\hline & $16: 20$ & & & & Pulled Feed, CT, PCT, SCT \& KDL Samples \\
\hline & $16: 25$ & $6: 00$ & $107: 35$ & & System shut down \\
\hline \multirow[t]{4}{*}{ Fri } & $8: 30$ & & & & Started jet pump and reboiler \\
\hline & $8: 50$ & & & & Boiling started \\
\hline & $15: 45$ & & & & Pulled Feed, CT, PCT, SCT \& KDL Samples \\
\hline & $15: 50$ & $7: 00$ & $97: 35$ & & System shut down \\
\hline $10 / 27 / 03$ & $9: 55$ & & & & Started steam generator \\
\hline \multirow[t]{4}{*}{ Mon } & $10: 00$ & & & & Started jet pump and reboiler \\
\hline & $10: 15$ & & & & Boiling started \\
\hline & $13: 15$ & & & & Pulled Feed, CT, PCT, SCT \& KDL Samples \\
\hline & $14: 15$ & 4:00 & $101: 35$ & & System shut down \\
\hline $10 / 28 / 03$ & $8: 15$ & & & & Started steam generator \\
\hline \multirow[t]{6}{*}{ Tue } & $8: 20$ & & & & Started jet pump and reboiler \\
\hline & $8: 35$ & & & & Boiling started \\
\hline & 14:00 & & & & System shut down \\
\hline & $15: 50$ & & & & System started again, boiling started \\
\hline & $16: 20$ & & & & Pulled Feed, CT, PCT, SCT \& KDL Samples \\
\hline & $16: 25$ & $6: 00$ & $107: 35$ & & System shut down \\
\hline
\end{tabular}




\subsection{TEST RESULTS}

\subsubsection{Foaming/Antifoam Results}

One of the Pilot-Scale Evaporator test program objectives was to determine any foaming issues associated with different evaporation campaigns. Additionally, the test program was designed to test the effectiveness of an antifoam agent (Dow Corning Q2-3183A).

Note that the evaporator system operates under vacuum. After the initial boil-off, the system is essentially degassed. Typically, within 20-30 minutes of the startup, target vacuum level (1 psia) was achieved and stable boiling conditions were established with $\sim 1-2$ feet of froth/foam zone. Any small addition of air for a few seconds into the recirculation loop resulted in a dramatic increase in the froth height, up to the lower demister. This was observed due to the recirculation pump seal failure. Since the entire system is under vacuum, the failed seal allowed atmospheric air to be entrained into the evaporator vessel. No effort was made to measure the air in-leakage rate. This effect is independent of addition of antifoam agent. All evaporator tests were performed without any air in-leakage into the evaporator vessel.

Dow Corning Q2-3183A antifoam agent was used for both Test 1 and Test 2. Contents plus CAS numbers of this antifoam agent are listed below.

1. Polypropylene glycol

2. Polydimethylsiloxane

3. Treated Silica

4. Octylphenoxy polyethoxy ethanol

5. Polyether polyol

6. Treated amorphous silica

7. Treated Silica
25322-69-4

63148-62-9

NJ TSRN 14962700-5005P

9036-19-5

9082-00-2

NJ TSRN 14962700-5149P

\subsubsection{Foaming/Antifoam Addition for Test 1}

It is important to note at the outset that the boiling surface/zone undergoes a fairly turbulent and violent flashing of superheated fluid. This active zone contains vapor bubbles and liquid droplets of various sizes. This zone is more or less like froth since it collapses as soon as the boiling process ceases. No significant stable foam was observed when the boiling stopped. However, the froth zone can be as high as 5-6 feet with occasional splattering of liquid droplets hitting the lower demister pad. In this report, the words 'froth' and 'foam' are used interchangeably.

Foaming was noted during the waste feed evaporation run, as shown in Figure 2-3. The foaming was highest ( $\sim 5$ feet) during initial concentration of the feed from the dilute $(<1 \mathrm{M}$ $\mathrm{Na}$ ) initial concentration to a specific gravity of 1.22 . The foam was vigorously buffeted by the escaping vapors resulting in a significant amount of splatter. The demister pads were routinely hit by the splatter during initial boil-off. After the initial boil-off, the foam region stabilizes to about 24 inches high. 


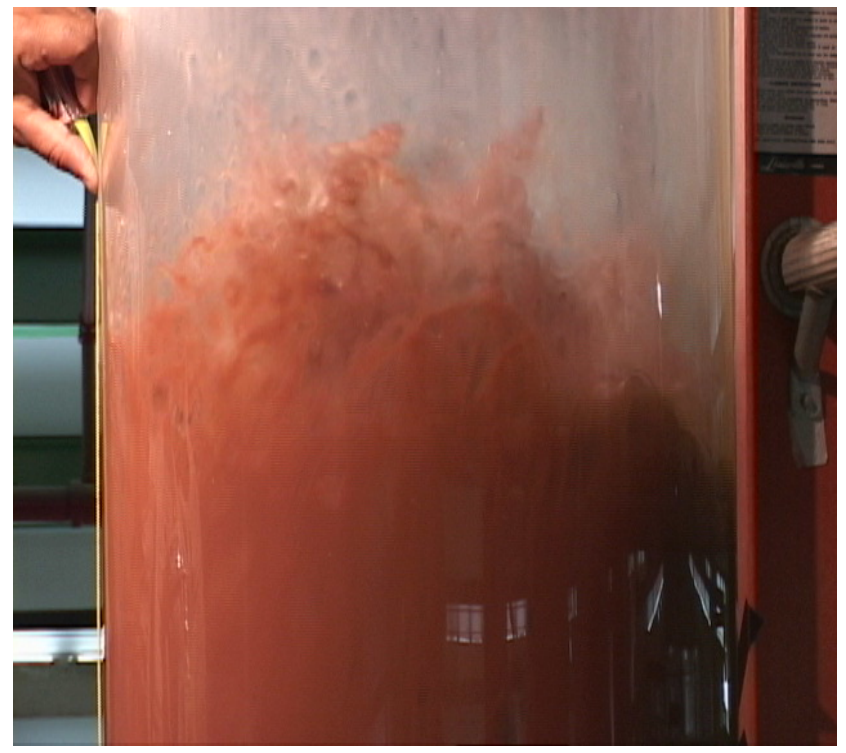

Figure 2-3. Foaming during Initial Concentration

The addition of 500 ppm of Dow Corning Q2 3183A antifoam significantly reduced the amount of foam noted, but did not eliminate the foam entirely, however, the height of the foam was reduced by approximately one half $\left(\sim 10^{\prime \prime}-12 "\right)$. Then another dose of $500 \mathrm{ppm}$ antifoam was injected with minor impact on the foam height $(\sim 8 ")$. Finally the last dose of $400 \mathrm{ppm}$ was added to achieve the target value of $1400 \mathrm{ppm}$. No additional decrease in foam height was observed. No degradation of the antifoam was noted during subsequent steadystate operation.

The fluctuations in vacuum increased the foaming and splattering during the test by causing short term increases in flux rate. When the vacuum is decreased, the boiling temperature rises and flux rate is decreased while the bulk slurry in the evaporator is heated until the new boiling temperature is reached. When the vacuum is increased, the boiling temperature is reduced and flux rate is significantly increased as the slurry in the evaporator is now in a superheated condition. Thus any pressure fluctuations in the system result in large fluctuations in instantaneous boil-off rates and associated foaming action.

\subsubsection{Foaming/Antifoam Addition for Test 2}

As described above, the total target concentration of antifoam agent was $1400 \mathrm{ppm}$. for Test 1, this target was reached by adding $500 \mathrm{ppm}, 500 \mathrm{ppm}$ and $400 \mathrm{ppm}$. During Test 1 antifoam addition, it was observed that the first dose of $500 \mathrm{ppm}$ was effective to reduce the froth/foam height and additional doses had only marginal effect. In view of this, for Test 2 , it was decided to add the antifoam agent in $100 \mathrm{ppm}$ increments and observe the effect on foam height. 
For Test 2, three doses of $100 \mathrm{ppm}$ of antifoam agent were found to be sufficient in minimizing the foam height. Figure 2-4 shows the foam height before any antifoam addition. The black triangular marks on the vessel are $1 \mathrm{ft}$ apart. Lower and upper yellow/black lines on left the measuring tape represent nominal liquid level and maximum liquid levels, respectively. The froth zone was nominally between $3-4 \mathrm{ft}$ high under stable boiling conditions. Liquid height in the evaporator was nominally $22 \mathrm{ft}$. Thus the froth/foam height was around $15-20 \%$. Note that the lower demister pad is about $6 \mathrm{ft}$ above the liquid level.

Figure 2-5 represents the foam after the first dose of $100 \mathrm{ppm}$. A significant reduction in foam height was observed. Nominally, the froth height reduced to $1-2 \mathrm{ft}$ range $(5-10 \%)$. Figure 2-6 shows the foam after the second dose of $100 \mathrm{ppm}$ (total $200 \mathrm{ppm}$ antifoam). The froth height dropped to less than $1 \mathrm{ft}(<5 \%)$. Later, another dose of $100 \mathrm{ppm}$ was added after 36 hours of operation since the froth height was getting slightly more than $1 \mathrm{ft}$. Minor reduction of foam height was observed and no further antifoam agent was added beyond the total $300 \mathrm{ppm}$ value. A stable froth/foam region remained around 8" high $(\sim 3 \%)$ for balance of the test duration as shown in Figure 2-7.

Note that in both tests, around 500ppm dose of antifoam agent was effective to control the foaminess. However, the Pilot-Scale tests were not designed to optimize the antifoam agent concentration levels. A more comprehensive bench scale study covering a wider range of waste simulants recommended $1400 \mathrm{ppm}$. The Pilot-Scale tests demonstrated that the recommended value is effective in controlling the foaminess.

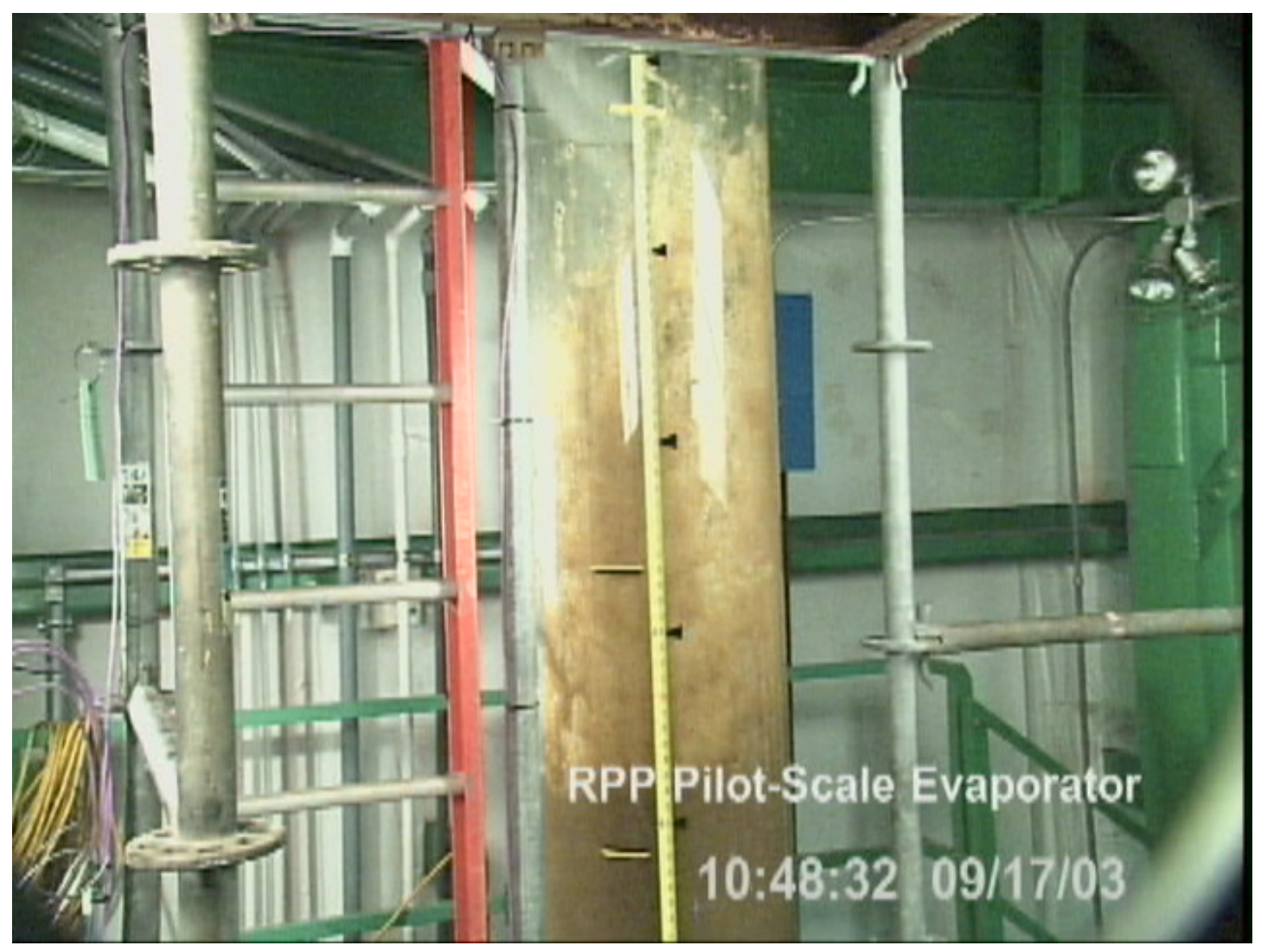

Figure 2-4. Foam Height Before Antifoam Addition 
WSRC-TR-2003-00561, REVISION 0 SRT-RPP-2003-00244, REVISION 0

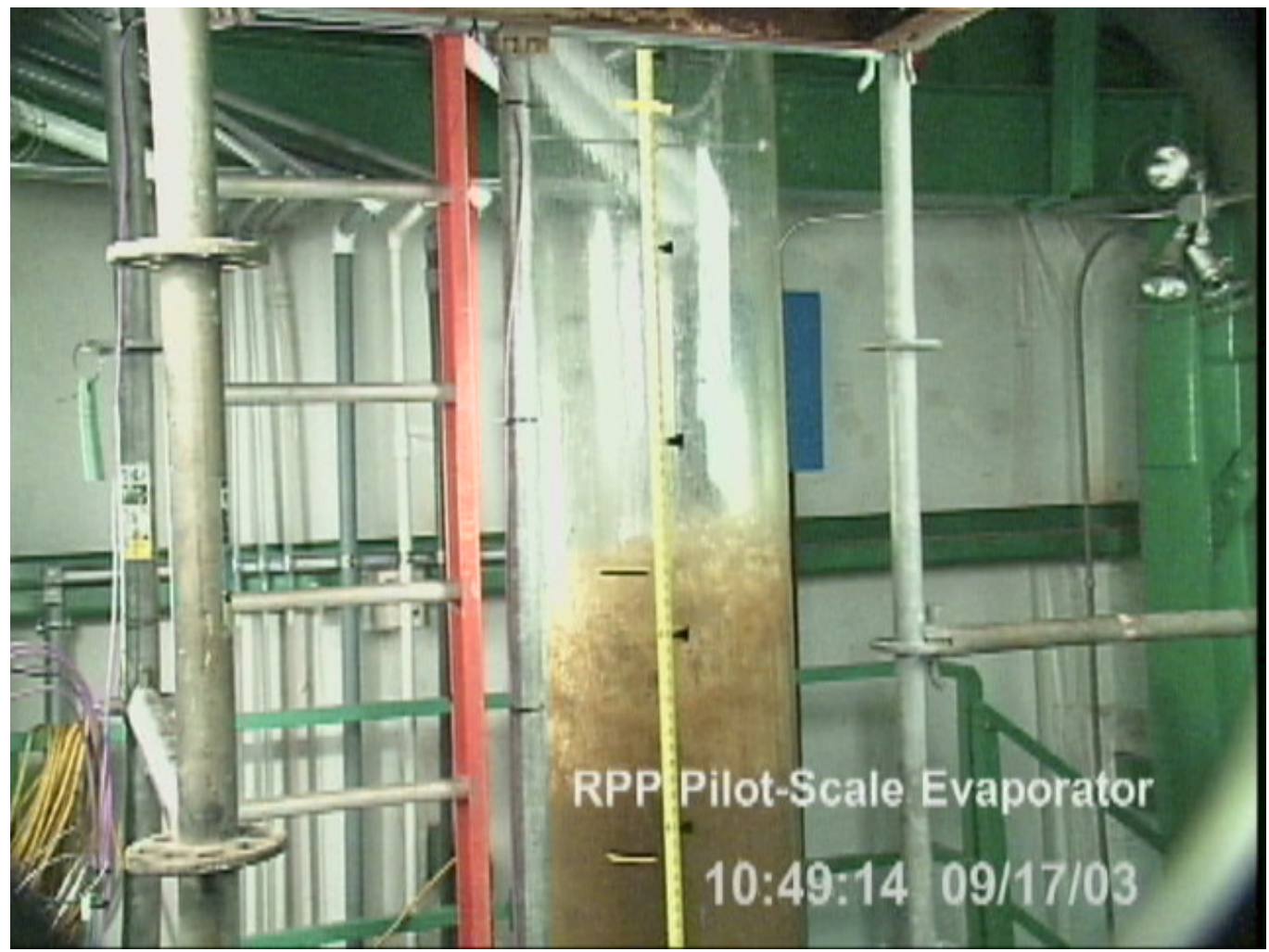

Figure 2-5. Foam Height After 100 ppm Antifoam Addition

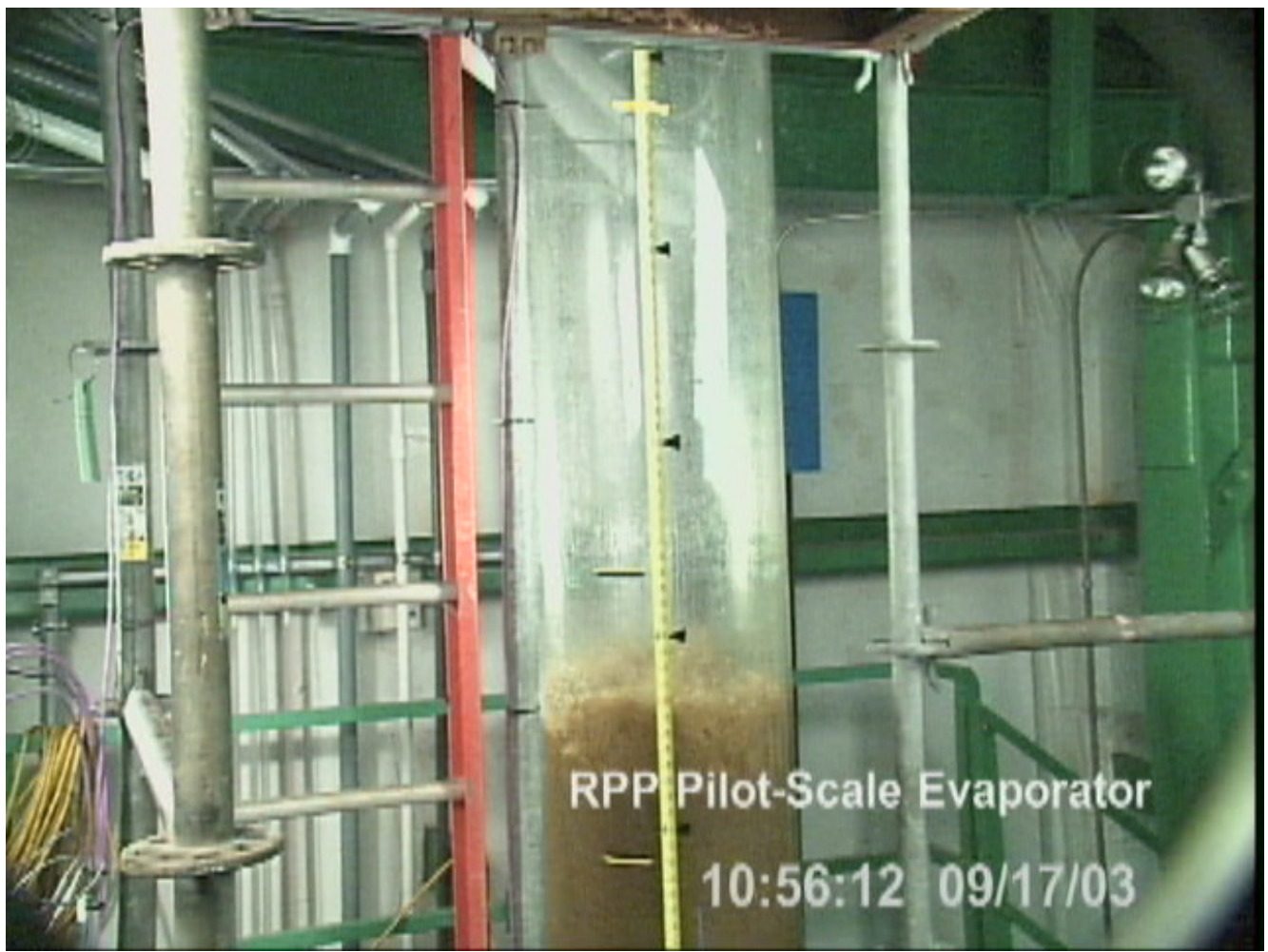

Figure 2-6. Foam Height After 200 ppm Antifoam Addition 


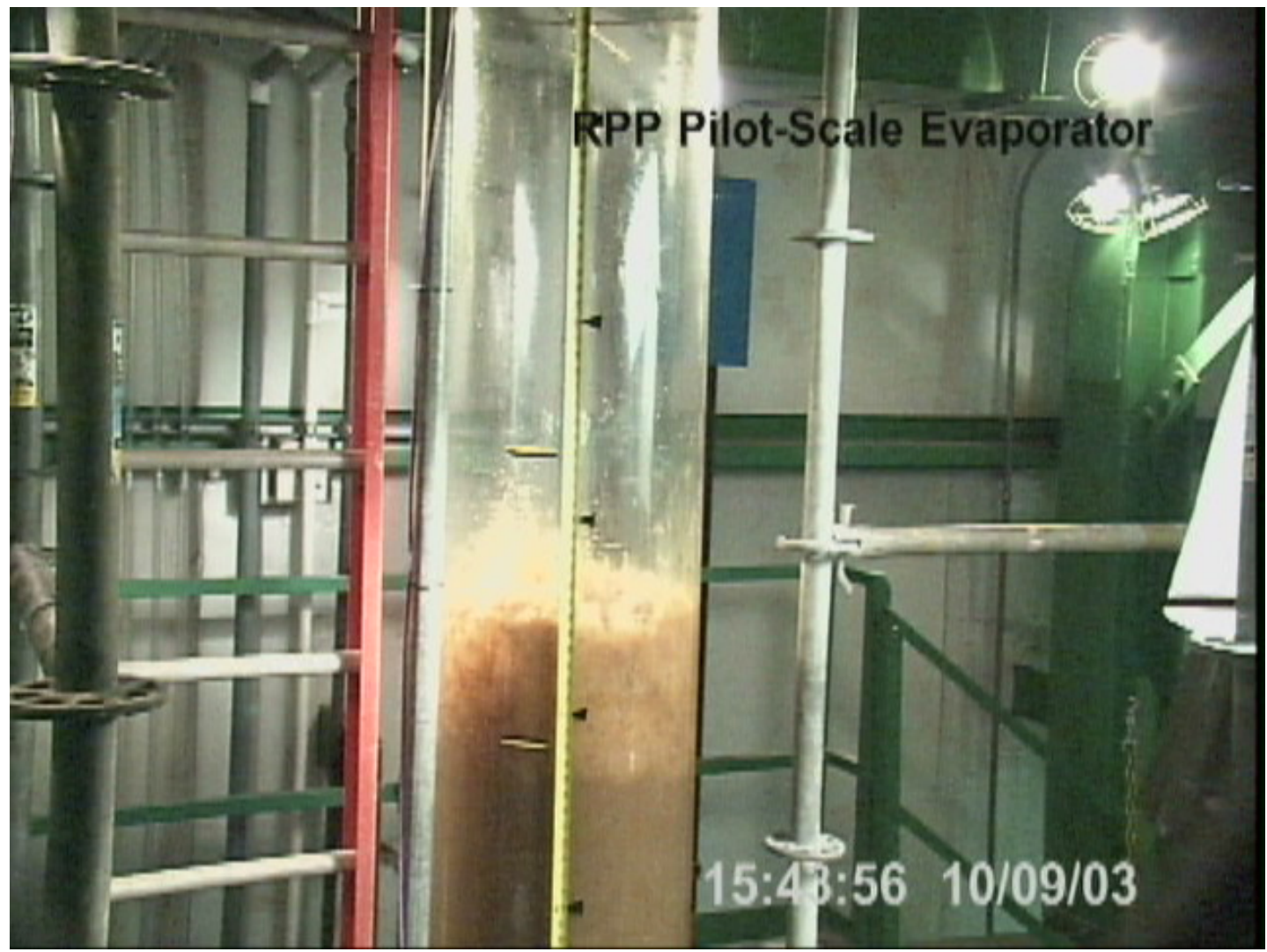

Figure 2-7. Foam Height After 300 ppm Antifoam Addition

\subsubsection{Decontamination Factors (DF) for Cesium}

\subsubsection{Cesium DF for Test 1}

Samples of the evaporator feed, concentrate, and condensate were pulled and analyzed for cesium content. The cesium decontamination factor was determined by dividing the $\mathrm{Cs}$ concentration in the concentrate by the Cs concentration in the primary condensate. The secondary condensate volume is an order of magnitude lower than the primary condensate volume, therefore it was not included in the calculation. The concentrate value was utilized for the Cs concentration due to the length of time that the vessel boiled under steady-state conditions. The final sample results are shown in Table 2-5along with the calculated decontamination factors and amounts of cesium removed by the primary and secondary condensate from the evaporation system.

Table 2-5. Cesium Results and Decontamination Factor

\begin{tabular}{|c|c|c|c|c|c|}
\hline $\begin{array}{c}\text { Cs } \\
\text { in Feed }\end{array}$ & $\begin{array}{c}\text { Cs } \\
\text { in Concentrate }\end{array}$ & $\begin{array}{c}\text { Cs in Primary } \\
\text { Condensate }\end{array}$ & $\begin{array}{c}\text { Cs in Secondary } \\
\text { Condensate }\end{array}$ & $\begin{array}{c}\text { Cs in Knockout } \\
\text { Pot Drain Loop }\end{array}$ & Cs DF Factor \\
\hline$\mu \mathrm{g} / \mathrm{g}$ & $\mu \mathrm{g} / \mathrm{g}$ & $\mu \mathrm{g} / \mathrm{L}$ & $\mu \mathrm{g} / \mathrm{L}$ & $\mu \mathrm{g} / \mathrm{L}$ & \\
\hline 87.82 & 567 & 5.1 & 5.7 & 0.03 & 111,000 \\
\hline
\end{tabular}




\subsubsection{Composition Changes During Long Term Testing}

During the initial concentration phase of the Evaporator Test 2 from 9/15/03 to 9/16/03, the $\mathrm{Na}$ molarity of the evaporator concentrate went from about $3 \mathrm{M}$ to $12.5 \mathrm{M}$ as shown in Figure 2-8. The Na molarity of the concentrate then dropped to an average value of $10.8 \mathrm{M}$. The variance in the measured values is most likely due to changes in the feed as well as condensate rates as shown in Figure 2-9. Note that during the long term run, nominal feed rate and concentrate removal rates were adjusted to maintain a 100-gallon level in the evaporator at any given time. Sometimes to correct the concentrate level, large amounts of feed and concentrate were transferred using a 3/4" transfer line. The target density value was $88.4 \mathrm{lbm} / \mathrm{ft} 3$. The concentrate density in the evaporator vessel was maintained in the $88-89 \mathrm{lbm} / \mathrm{ft} 3$ range.

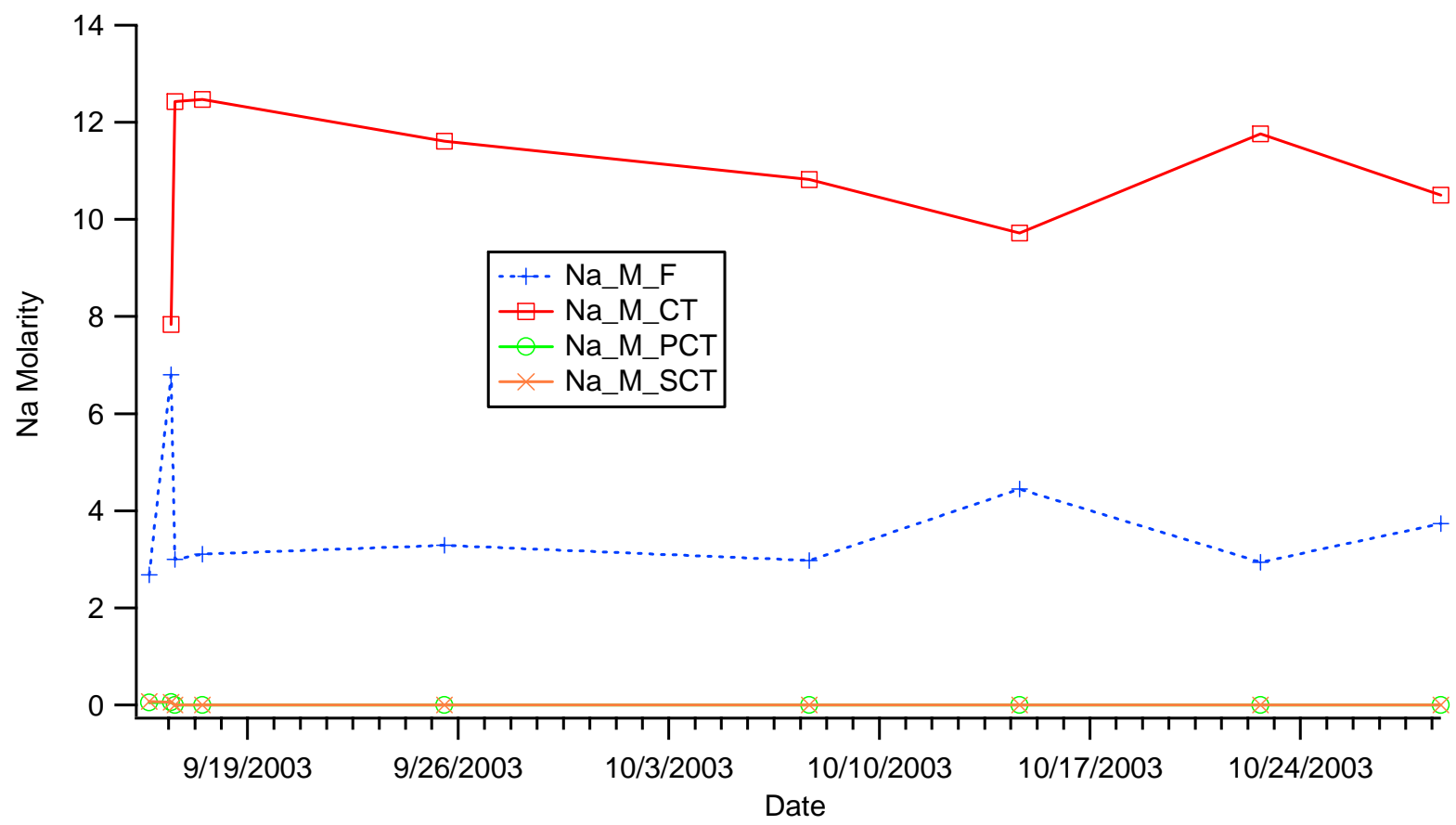

Figure 2-8. Na Molarity of Evaporator Feed (F), Concentrate Tank (CT), Primary Condensate Tank (PCT), and Secondary Condensate Tank (SCT) during Test 2 


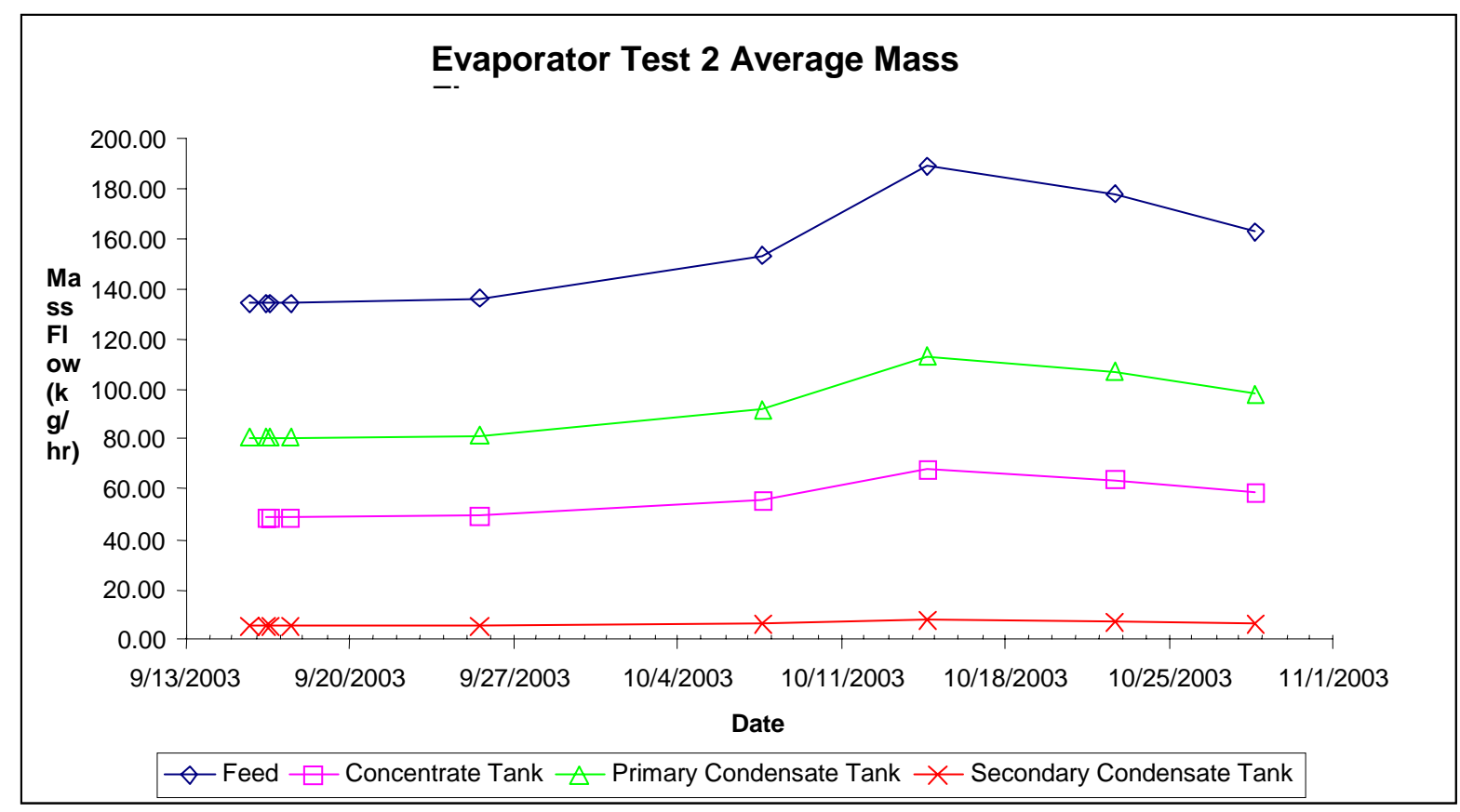

Figure 2-9. Evaporator Test 2 Average Mass Flow Rates

The concentration changes for all the elementals during Evaporator Test 2 can be categorized into multiple groups based on how much they changed over the course of the run. For the cations there were four changing groups: negligible, small, medium, and large. Small changes were observed for the cations $\mathrm{Ca}, \mathrm{Cd}, \mathrm{Cr}, \mathrm{Li}, \mathrm{Ni}, \mathrm{Pb}, \mathrm{Si}, \mathrm{Sn}, \mathrm{W}$, and $\mathrm{Zn}$ on the order of 100 ppm as shown in Figure 2-10 through Figure 2-13 for the various evaporator streams. Medium changes were observed for the cations Al, B, K, P, and S on the order of $5000 \mathrm{ppm}$ as shown in Figure 2-14 through Figure 2-17. Large changes were observed for the cation $\mathrm{Na}$ on the order of $50000 \mathrm{ppm}$ as shown in Figure 2-18 through Figure 2-21. The other cations (As, Ba, Ce, Co, Cu, La, Mg, Mn, Mo, Nd, Sr, Ti, Tl, V) had low concentrations or concentration changes less than $100 \mathrm{ppm}$.

The anions changed in a similar manner. There were three anion change groups: small, medium, and large. Of course, the magnitude of the changes was different from the cations. Small changes were observed for HCOO, CL, PO4, SO4, and C2O4 on the order of 5000 ppm as shown in Figure 2-22. Medium changes were noted for the anion NO2 (nitrite) on the order of $24000 \mathrm{ppm}$ as shown in Figure 2-24. Large changes were seen for the anion NO3 (nitrate) on the order of $60000 \mathrm{ppm}$ as shown in Figure 2-26. The anion changes in the Primary Condensate and the Secondary Condensate were not detectable or concentrations fell below detection limits.

Other than sodium, aluminum changes concentration more than the other cations. Some of this variance is due to changes in the feed and condensate rates. Some of the variance is also due to analytical error. The largest changing anion was NO3 followed by NO2 as expected in this nitrate rich system. Table 2-6 through Table 2-8 show the raw concentrations for the cations and anions. 
WSRC-TR-2003-00561, REVISION 0

SRT-RPP-2003-00244, REVISION 0

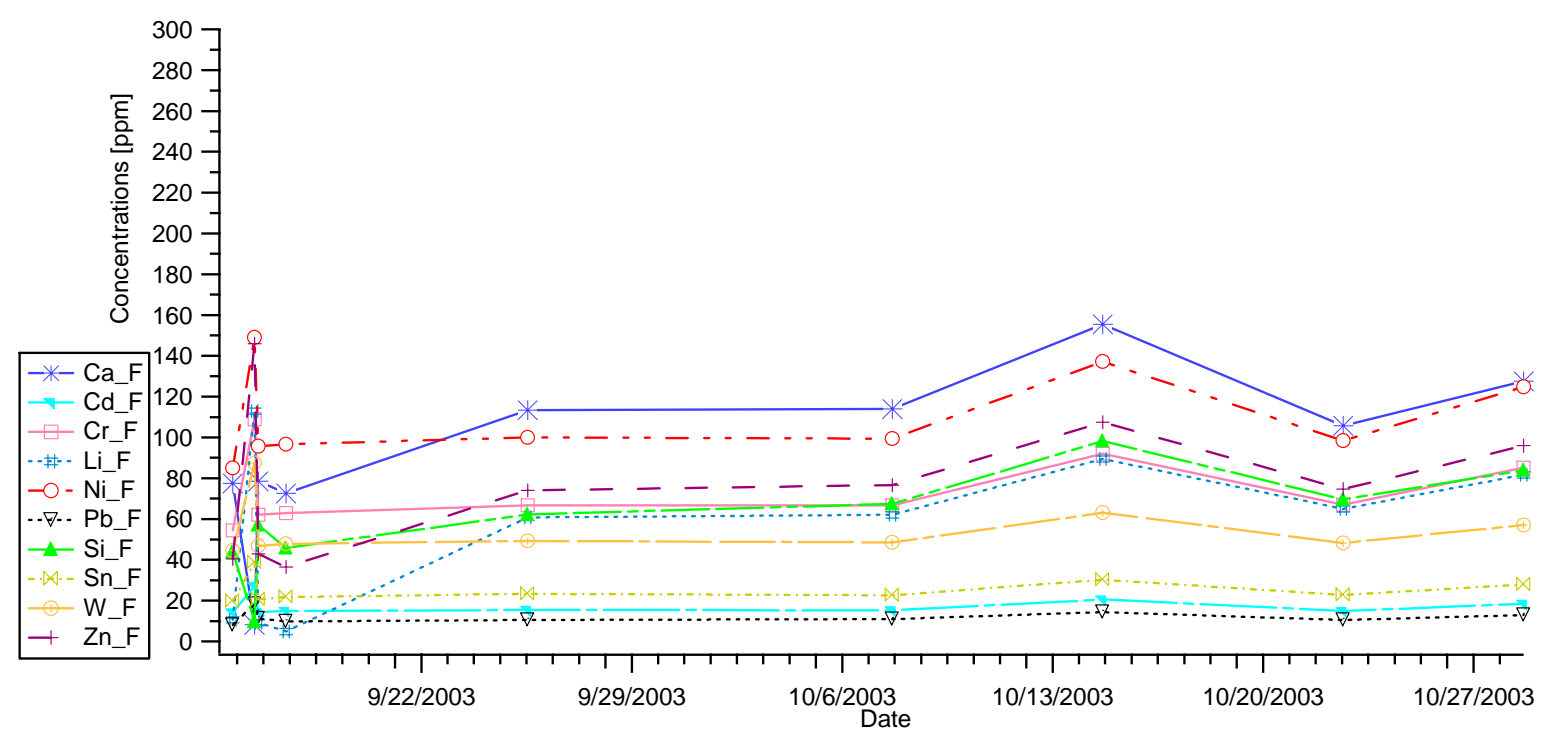

Figure 2-10. Evaporator Run 2 Feed (F) Concentrations in ppm for Small Changing Cations

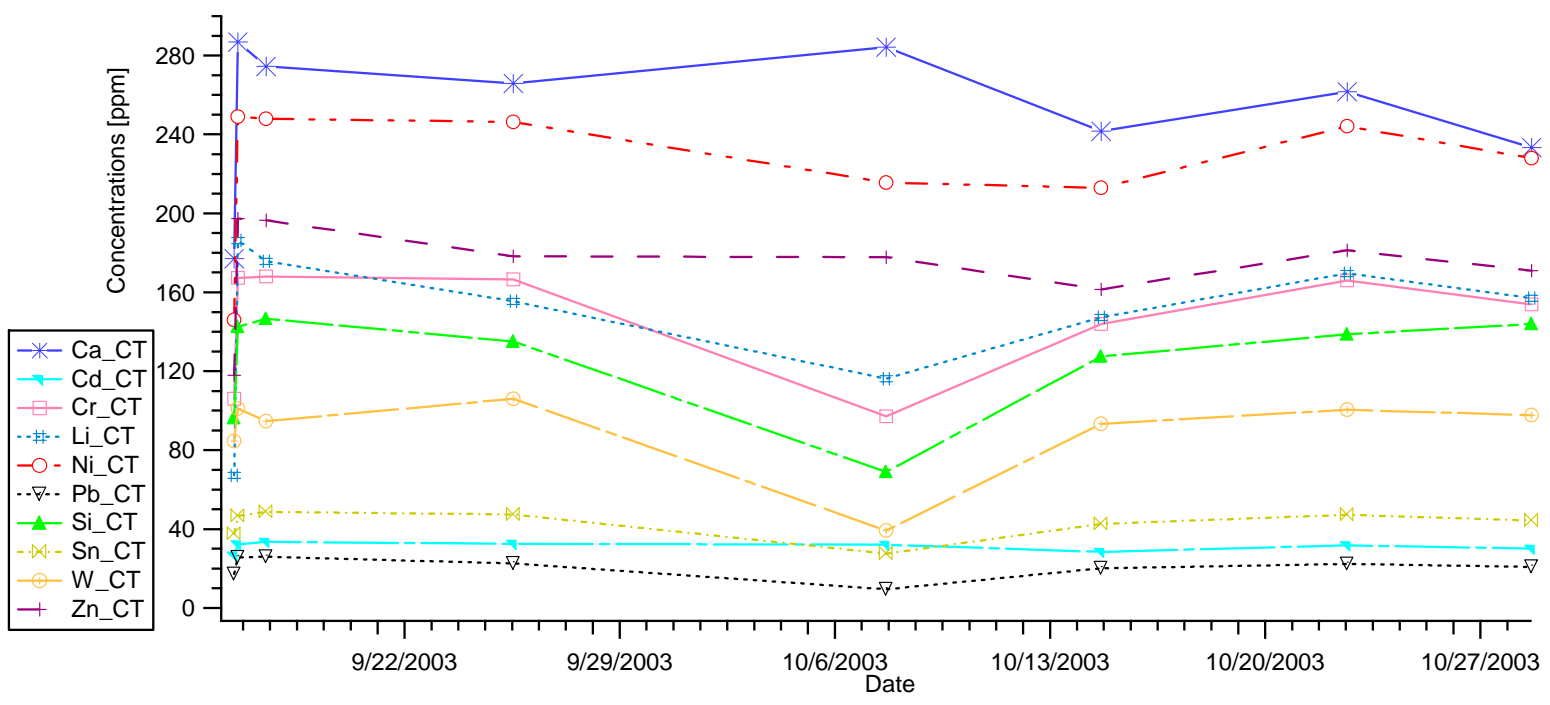

Figure 2-11. Evaporator Run 2 Concentrate Tank (CT) Concentrations in ppm for Small Changing Cations 
WSRC-TR-2003-00561, REVISION 0

SRT-RPP-2003-00244, REVISION 0

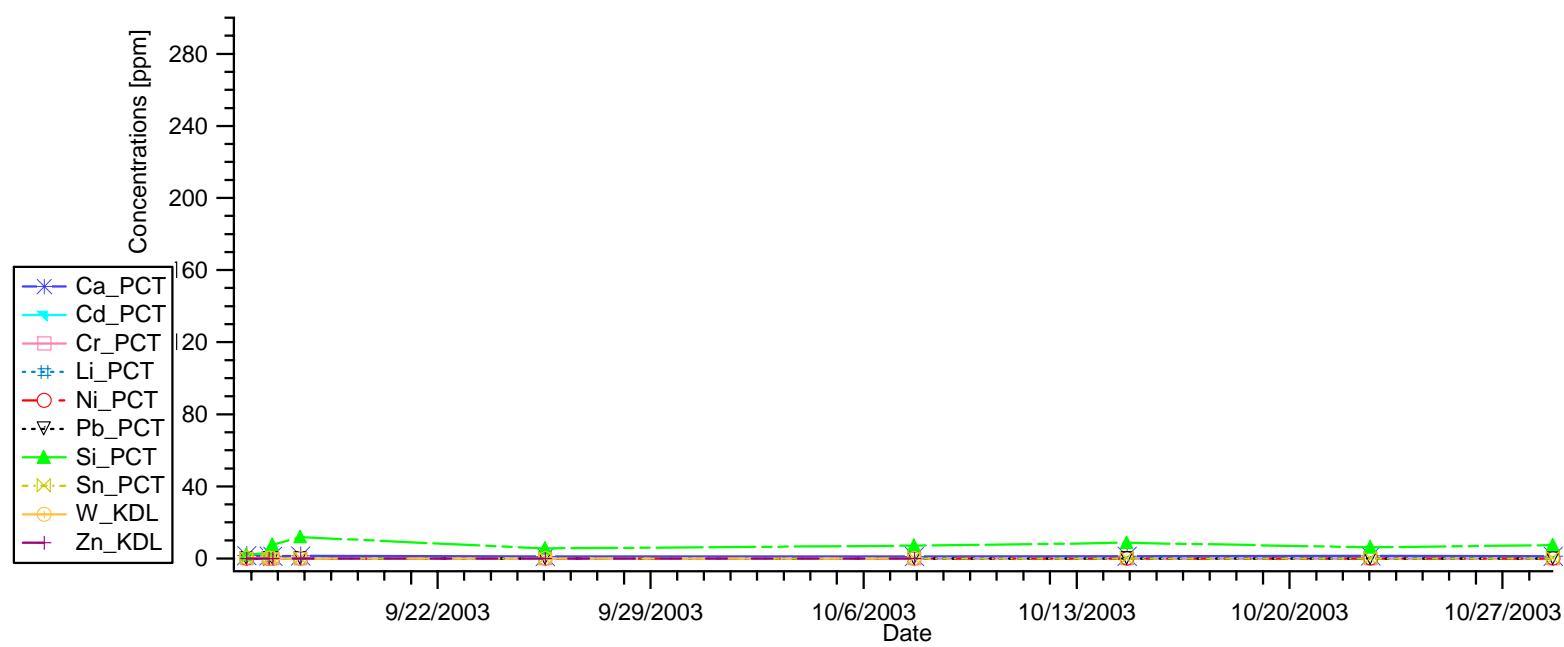

Figure 2-12. Evaporator Run 2 Primary Condensate Tank (PCT) Concentrations in ppm for Small Changing Cations

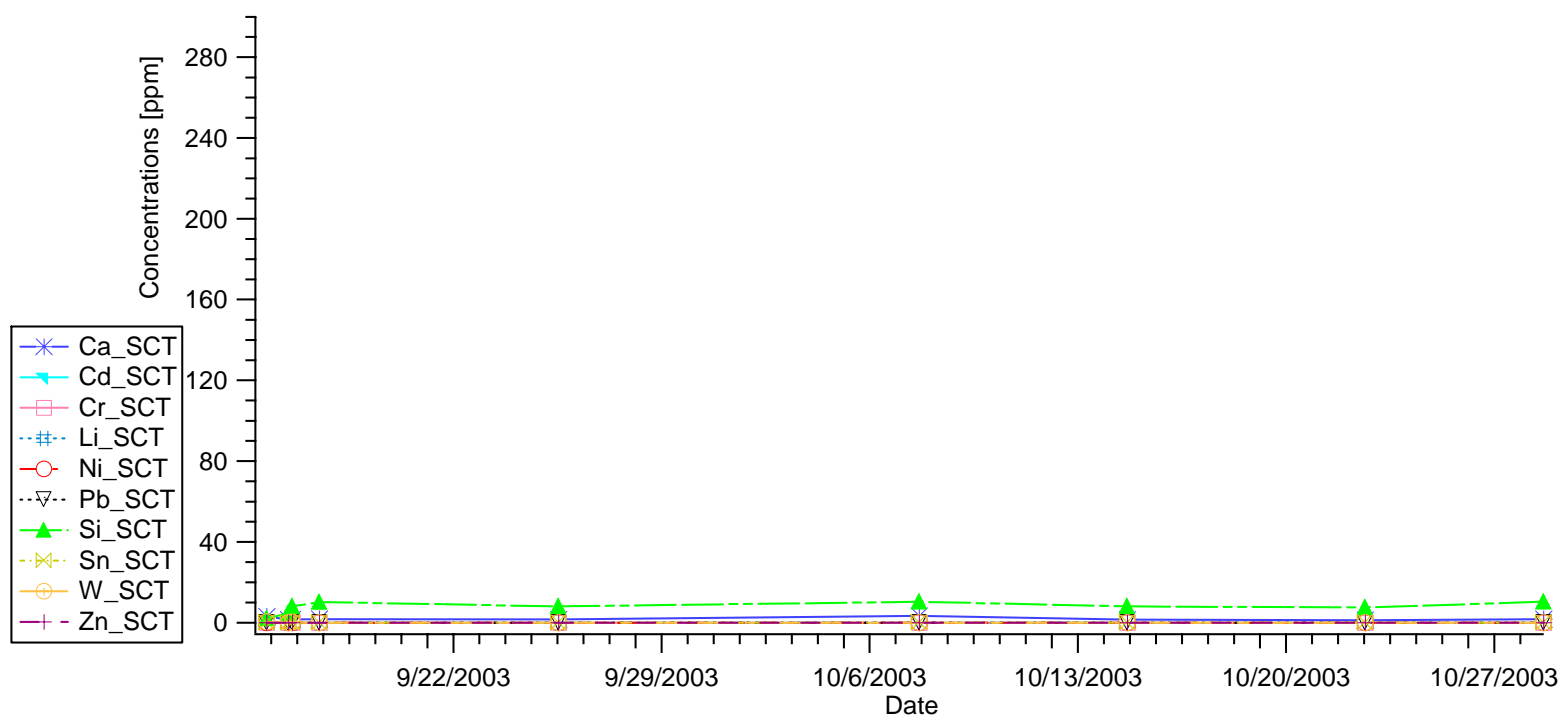

Figure 2-13. Evaporator Run 2 Secondary Condensate Tank (SCT) Concentrations in ppm for Small Changing Cations 
WSRC-TR-2003-00561, REVISION 0

SRT-RPP-2003-00244, REVISION 0

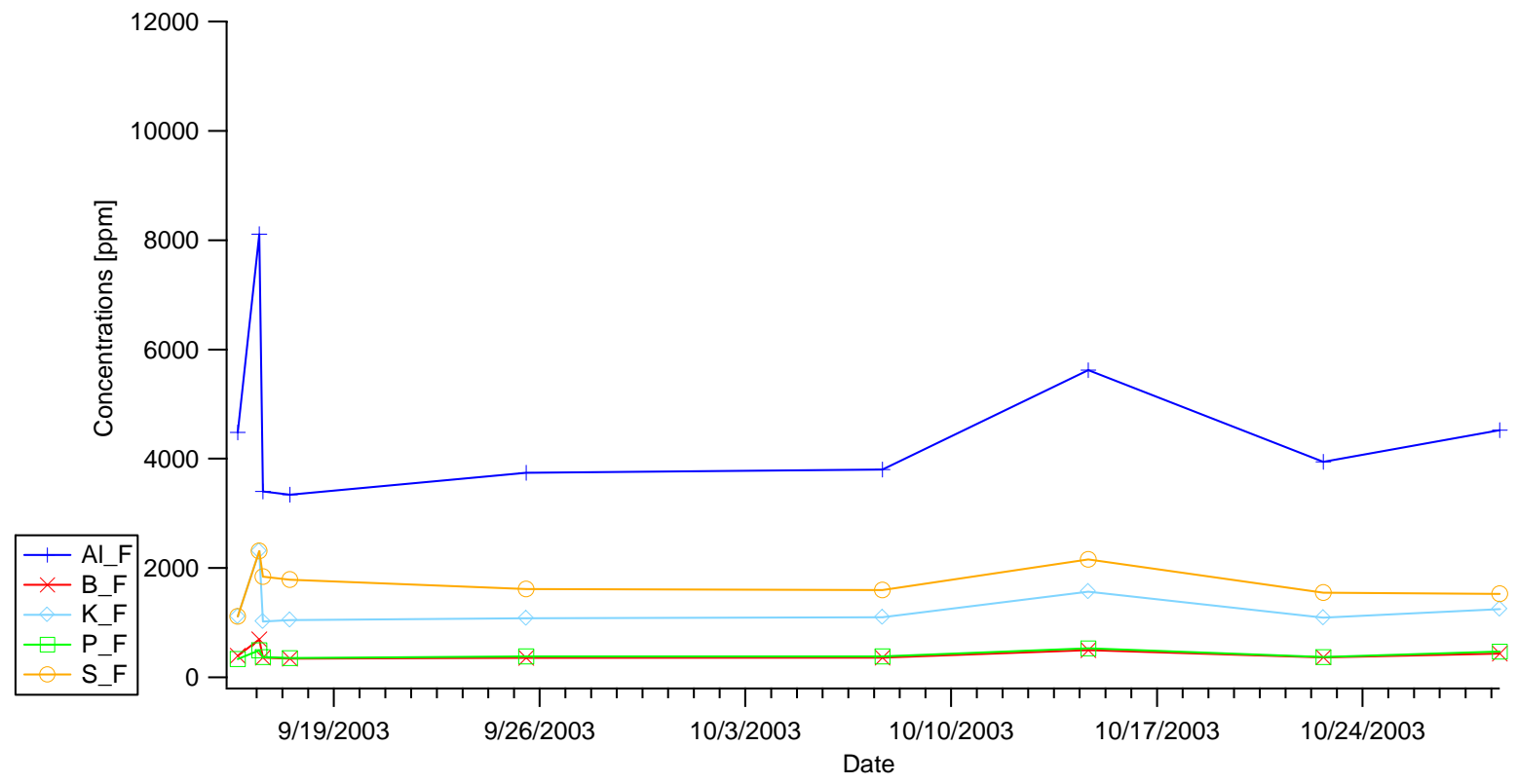

Figure 2-14. Evaporator Run 2 Feed (F) Concentrations in ppm for Medium Changing Cations

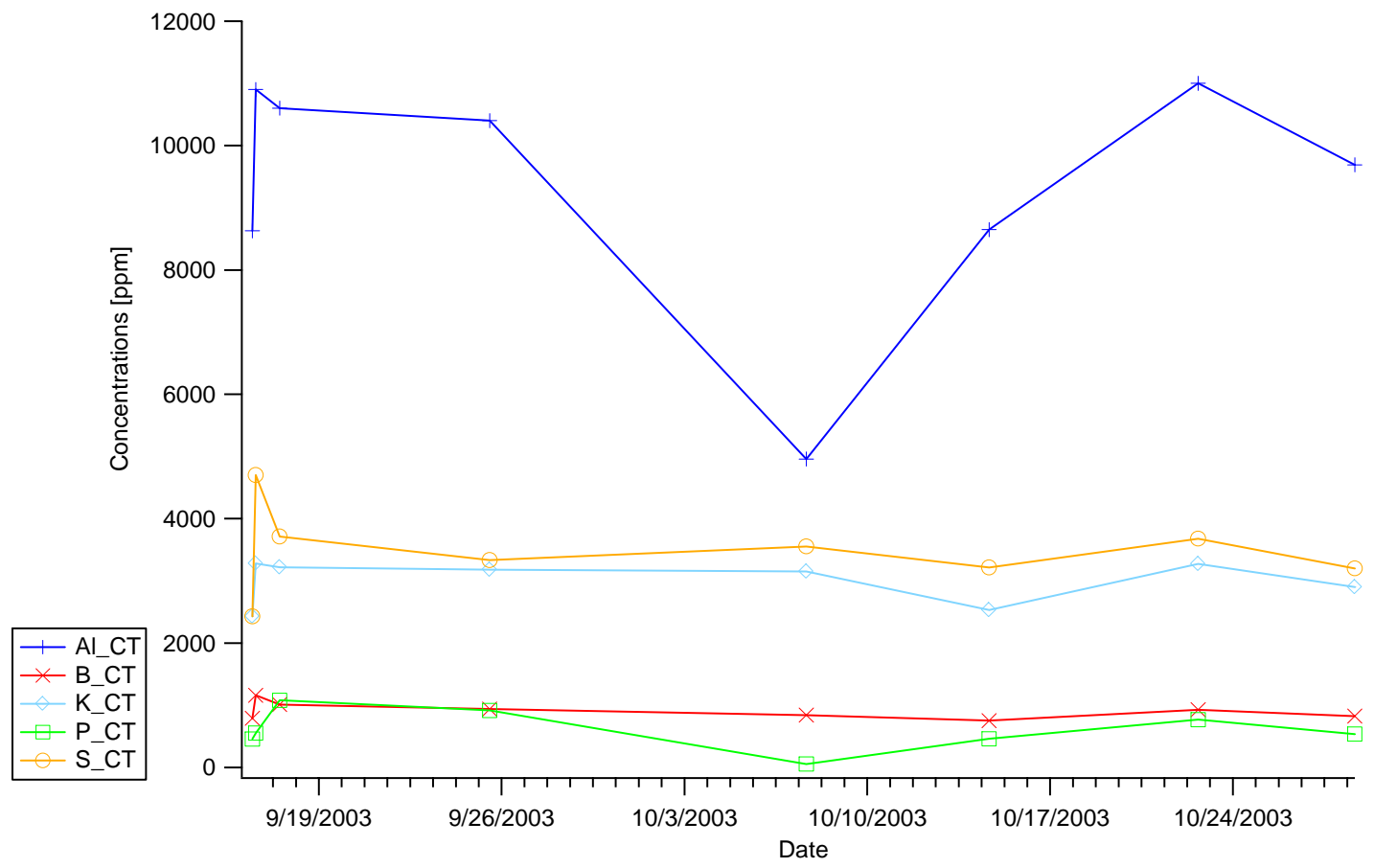

Figure 2-15. Evaporator Run 2 Concentrate Tank (CT) Concentrations in ppm for Medium Changing Cations 
WSRC-TR-2003-00561, REVISION 0

SRT-RPP-2003-00244, REVISION 0

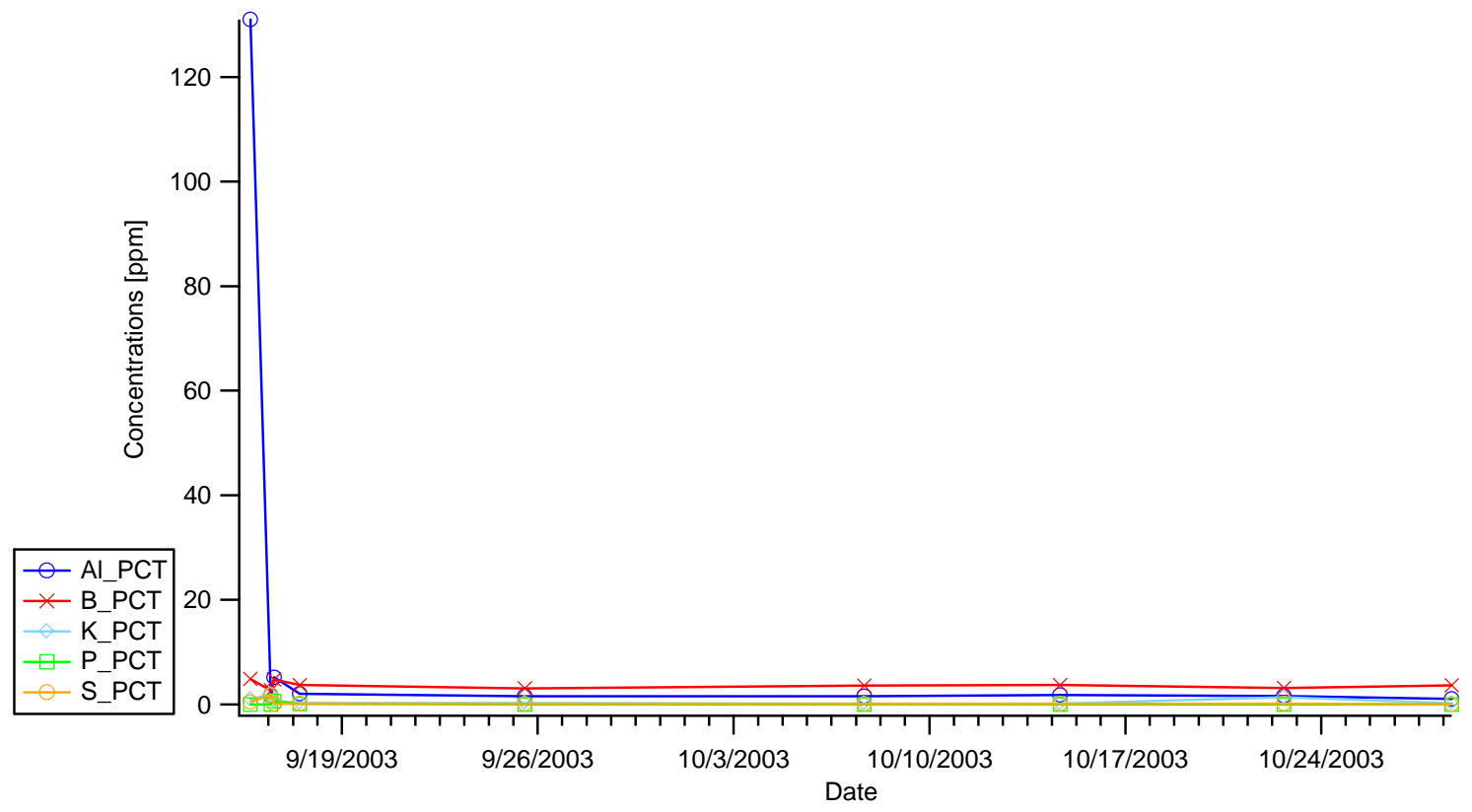

Figure 2-16. Evaporator Run 2 Primary Condensate Tank (PCT) Concentrations in ppm for Medium Changing Cations

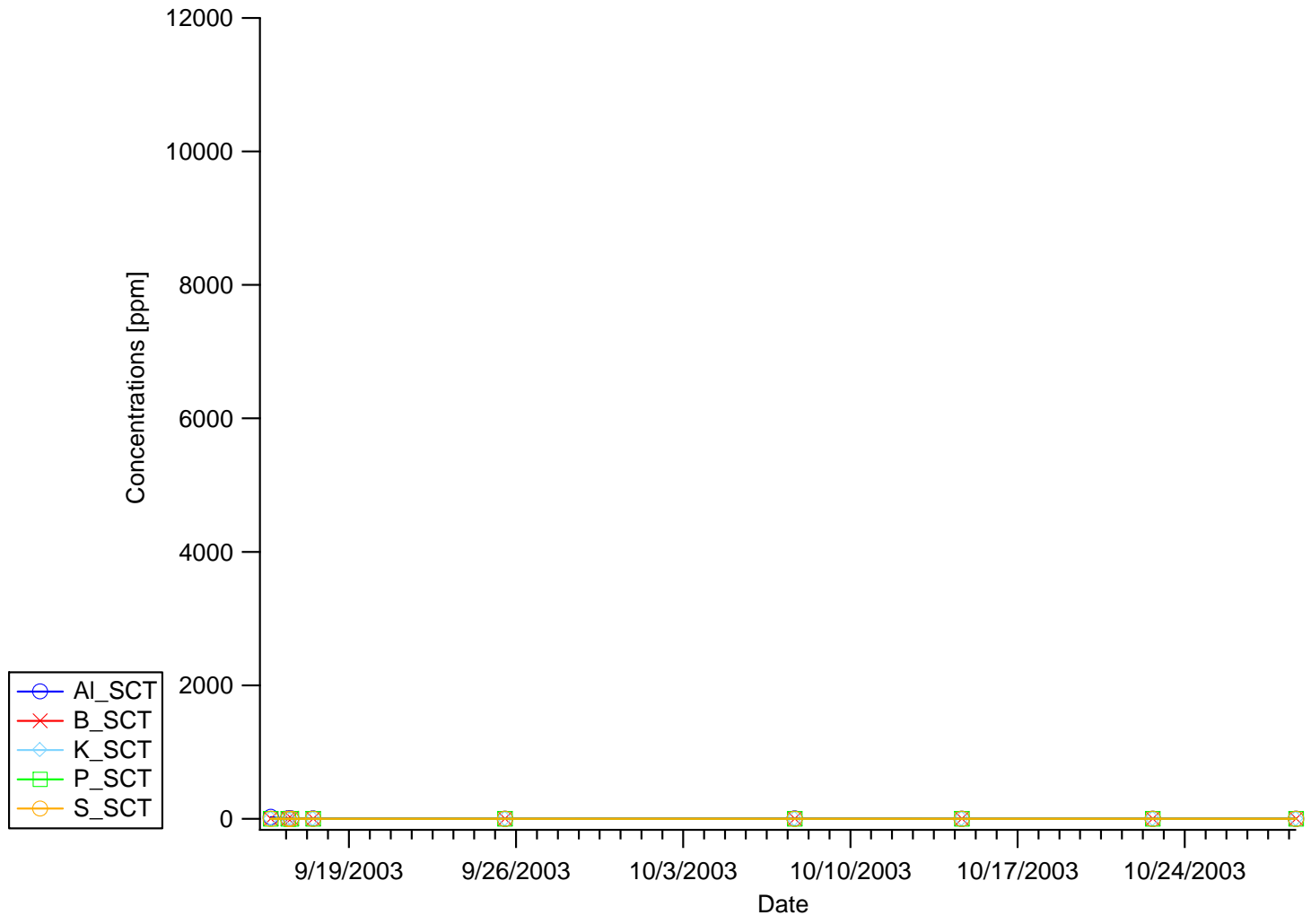

Figure 2-17. Evaporator Run 2 Secondary Condensate Tank (SCT) Concentrations in ppm for Medium Changing Cations 
WSRC-TR-2003-00561, REVISION 0

SRT-RPP-2003-00244, REVISION 0

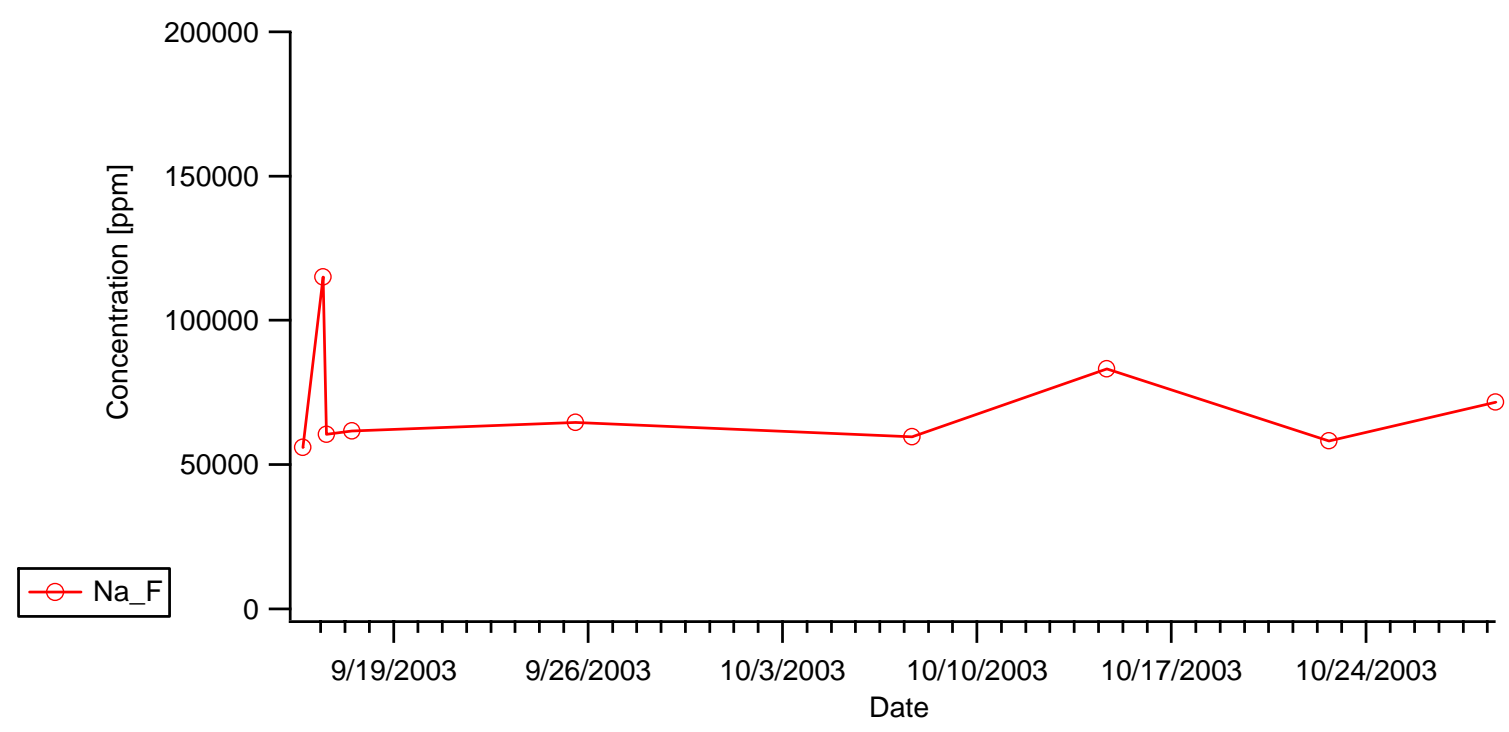

Figure 2-18. Evaporator Run 2 Feed (F) Concentrations in ppm for Large Changing Cations

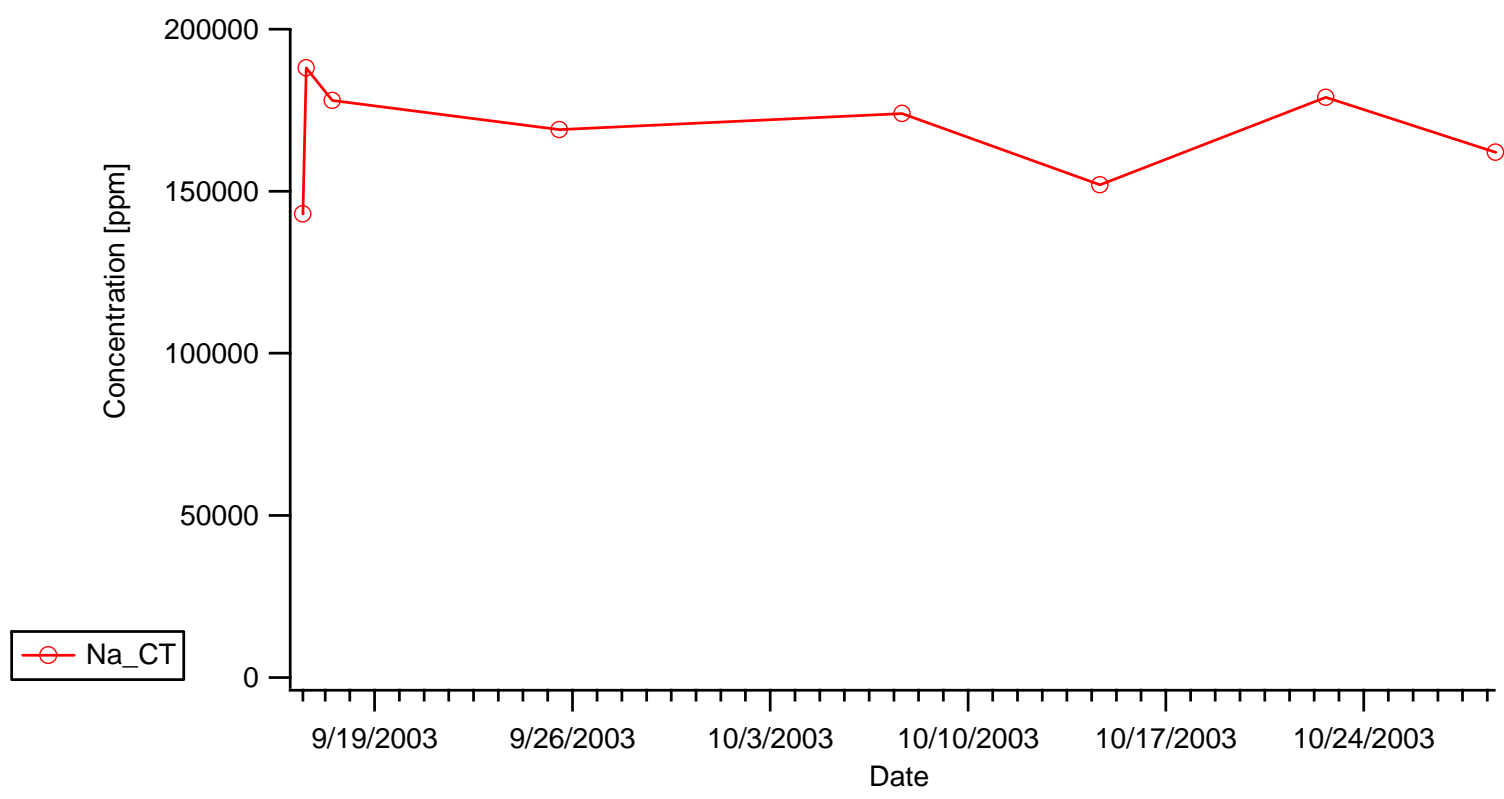

Figure 2-19. Evaporator Run 2 Concentrate Tank (CT) Concentrations in ppm for Large Changing Cations 
WSRC-TR-2003-00561, REVISION 0

SRT-RPP-2003-00244, REVISION 0

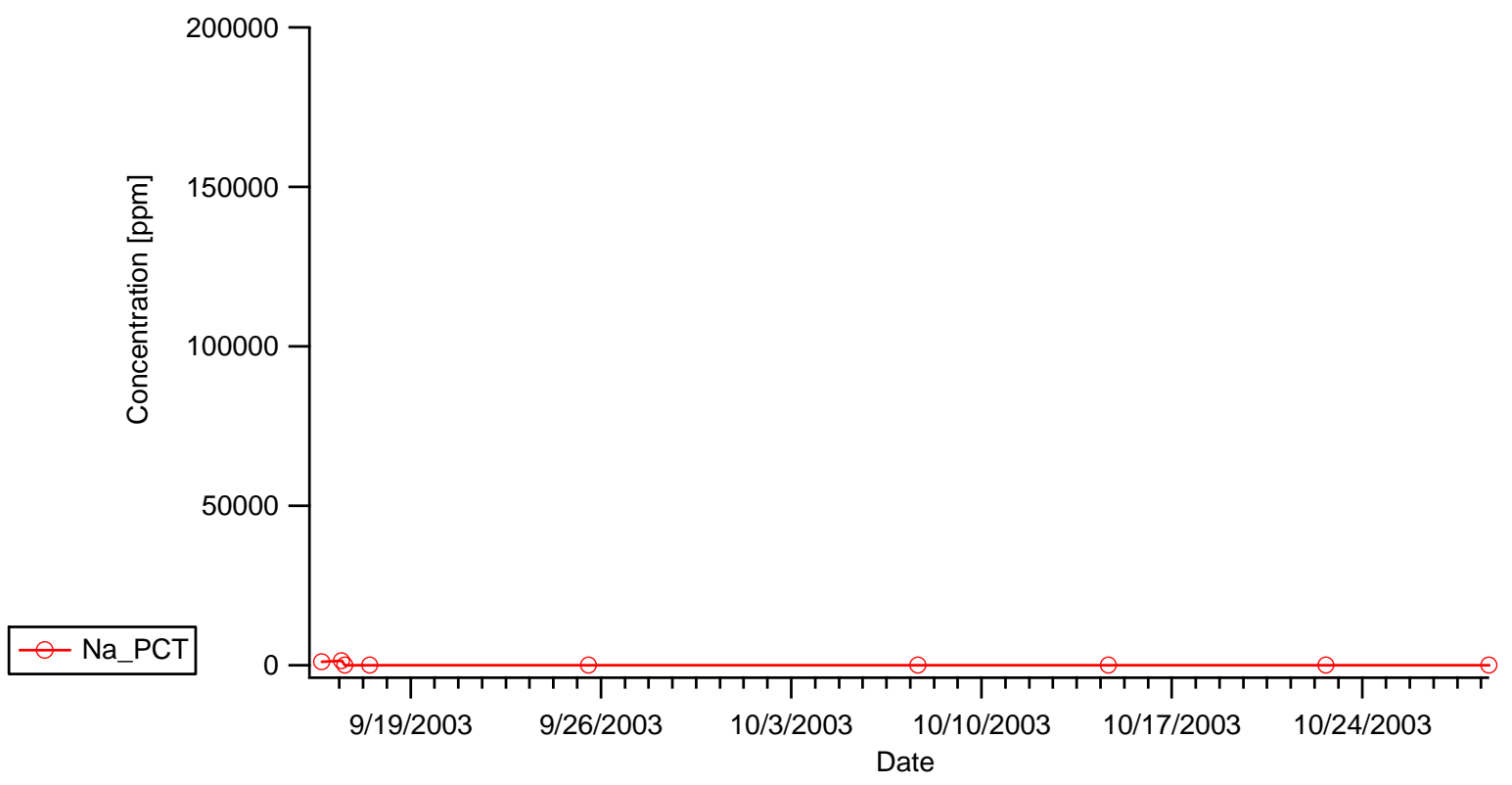

Figure 2-20. Evaporator Run 2 Primary Condensate Tank (PCT) Concentrations in ppm for Large Changing Cations

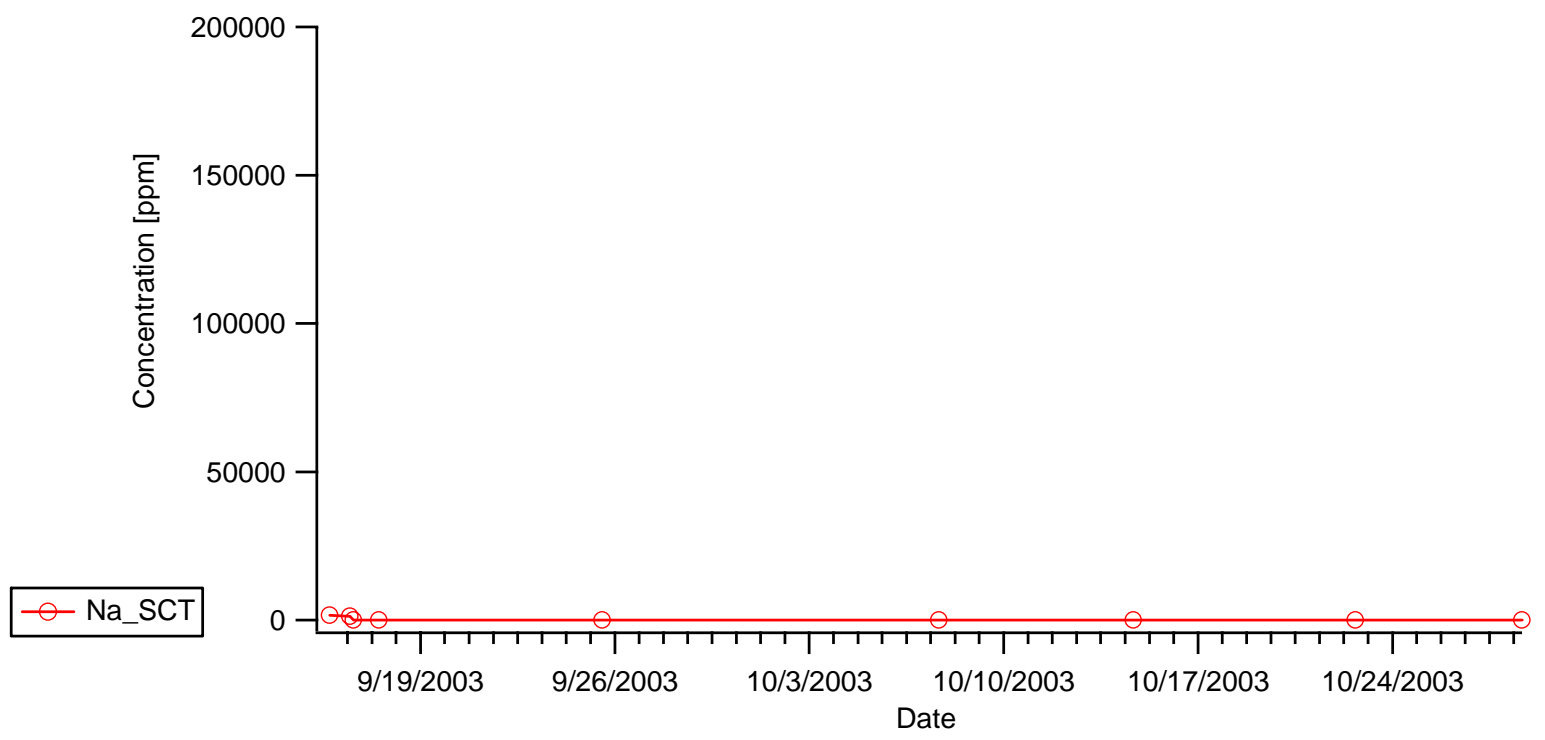

Figure 2-21. Evaporator Run 2 Secondary Condensate Tank (SCT) Concentrations in ppm for Large Changing Cations 
WSRC-TR-2003-00561, REVISION 0

SRT-RPP-2003-00244, REVISION 0

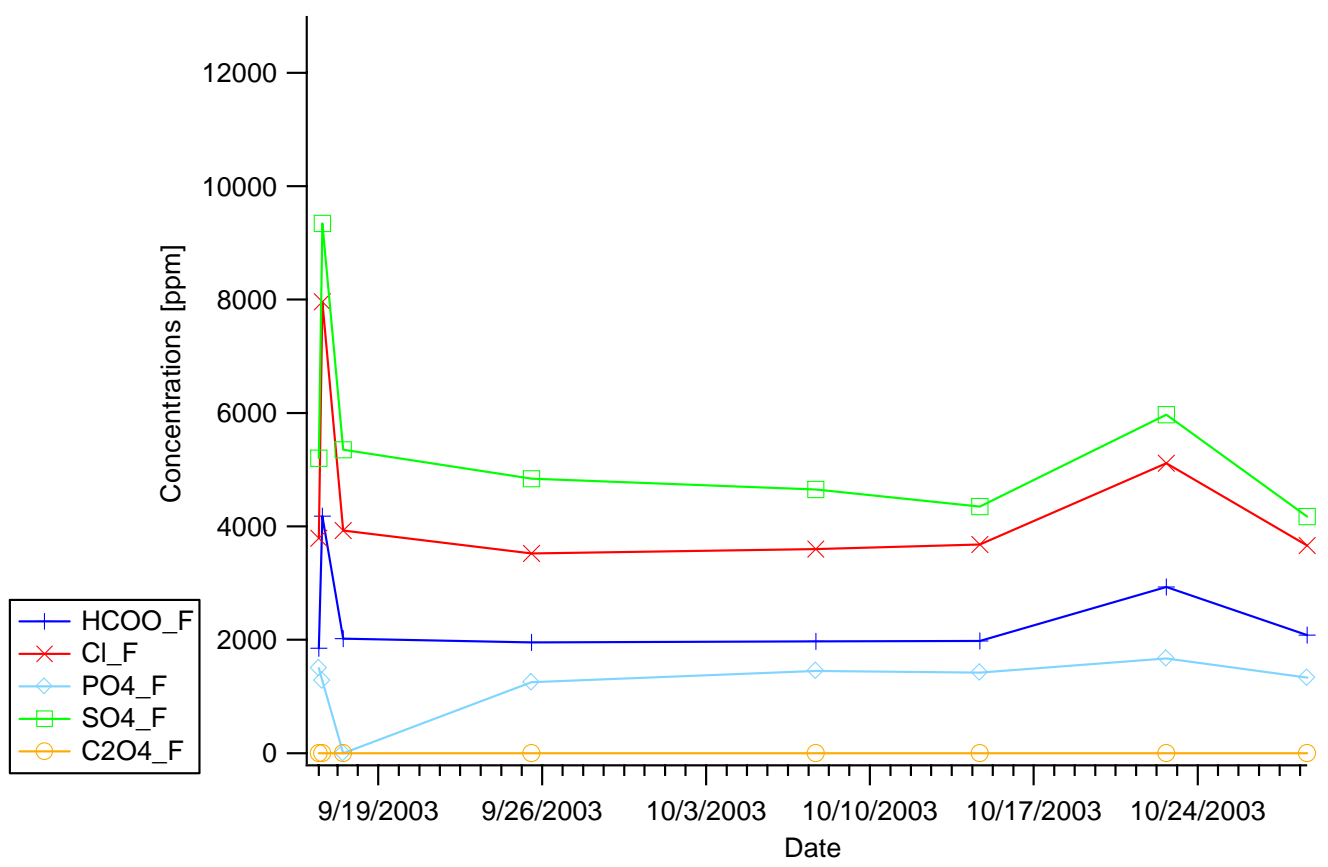

Figure 2-22. Evaporator Run 2 Feed Concentrations in ppm for Small Changing Anions

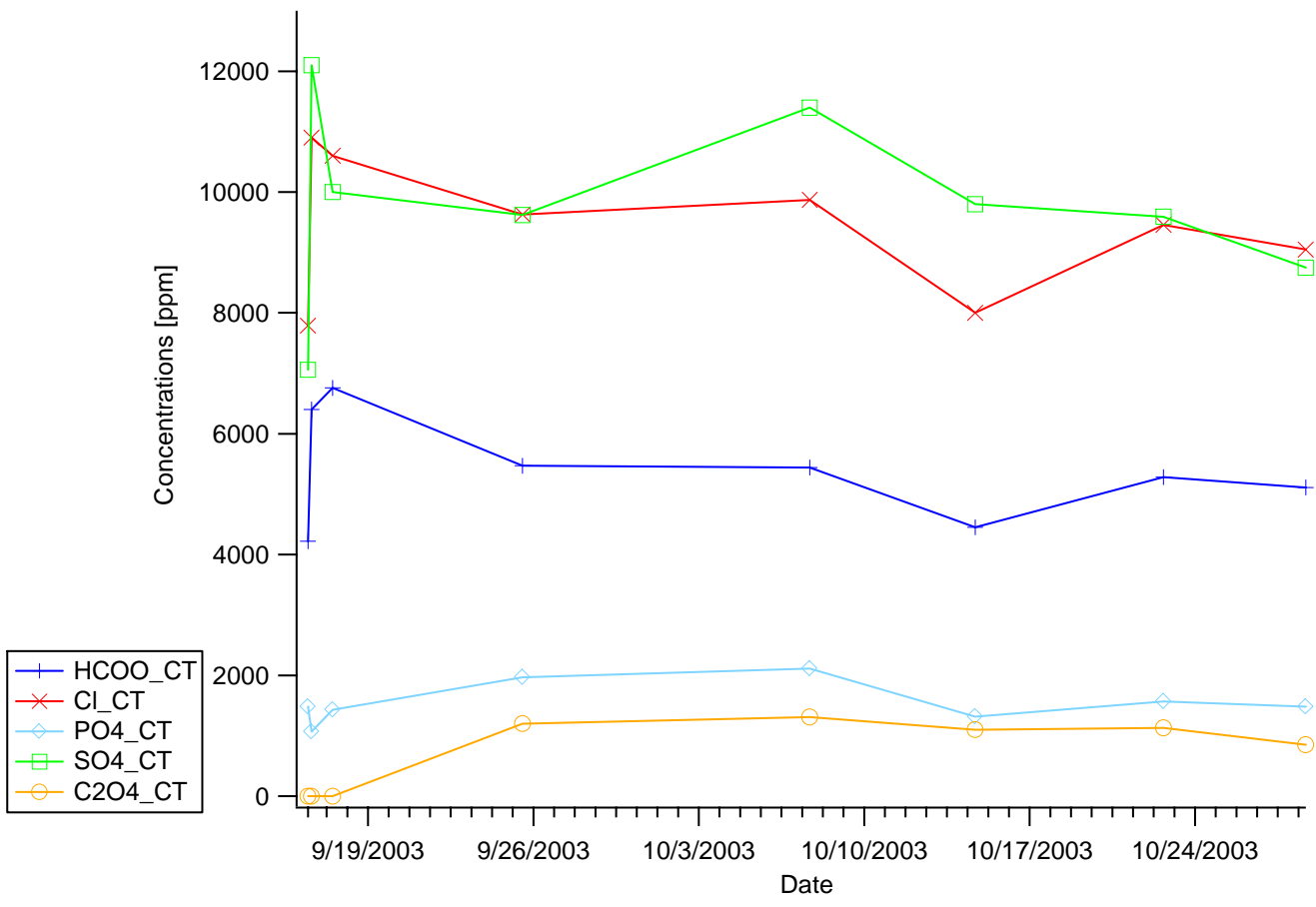

Figure 2-23. Evaporator Run 2 Concentrate Tank Concentrations in ppm for Small Changing Anions 
WSRC-TR-2003-00561, REVISION 0

SRT-RPP-2003-00244, REVISION 0

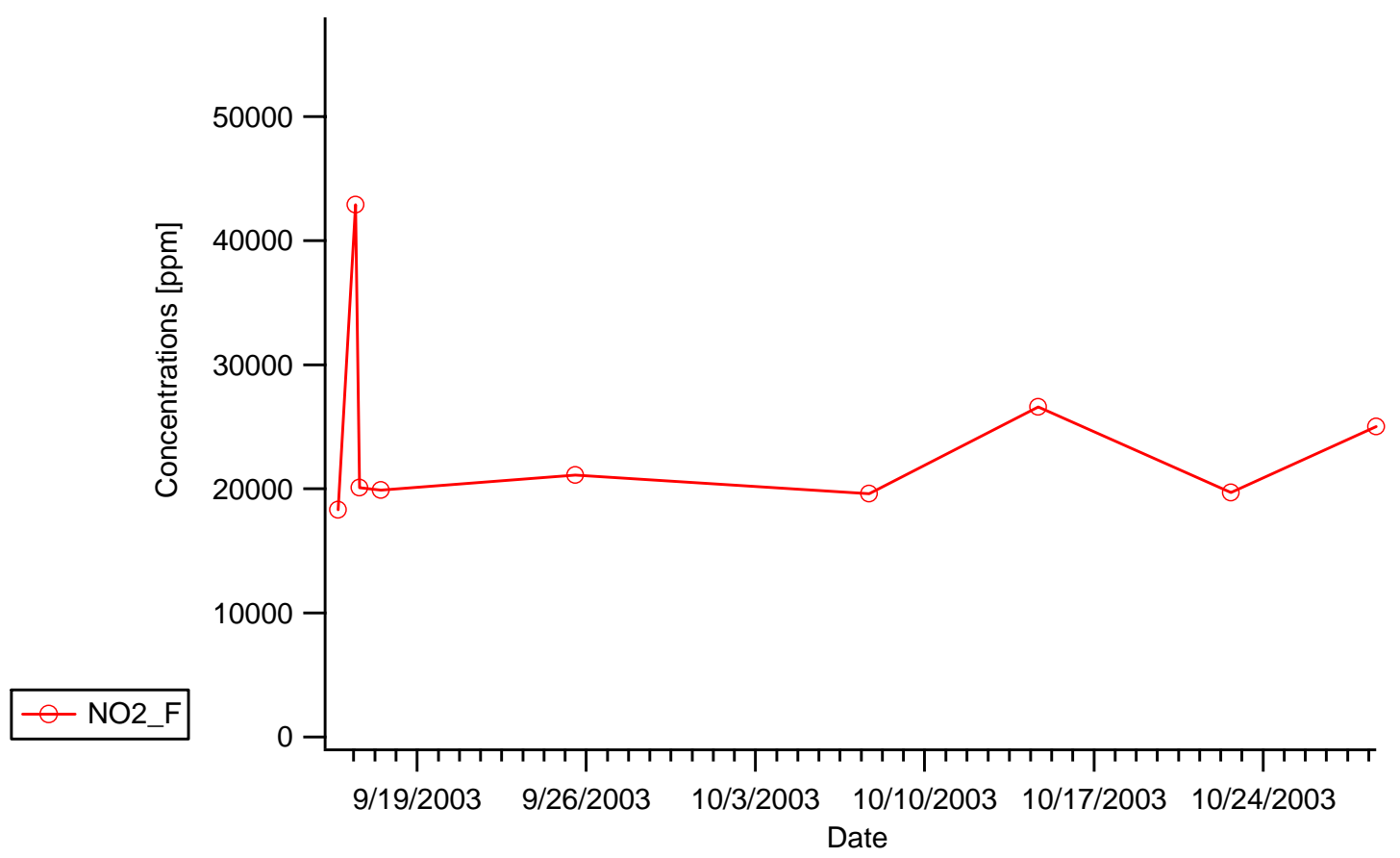

Figure 2-24. Evaporator Run 2 Feed Concentrations in ppm for Medium Changing Anions

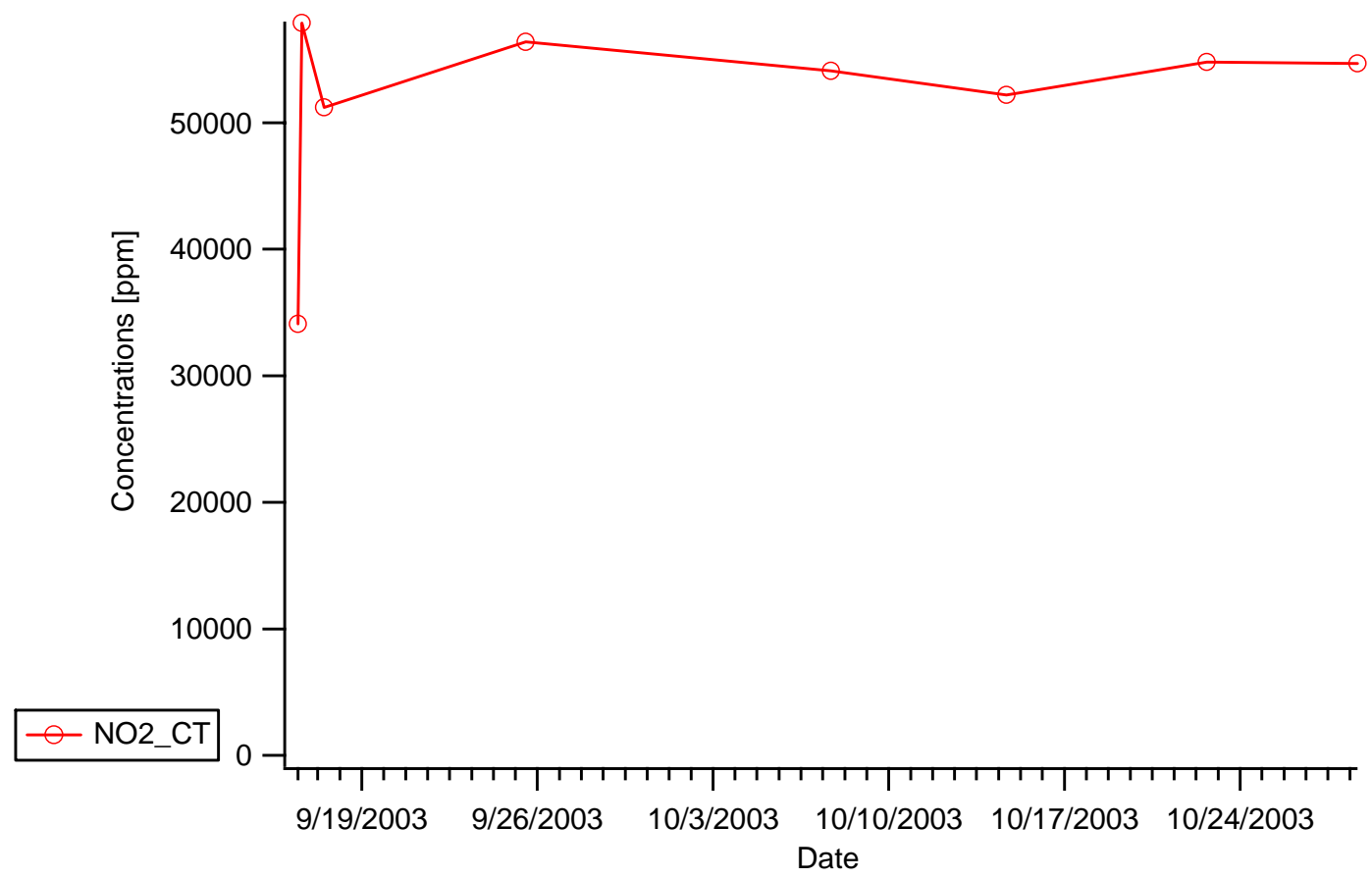

Figure 2-25. Evaporator Run 2 Concentrate Tank Concentrations in ppm for Medium Changing Anions 
WSRC-TR-2003-00561, REVISION 0

SRT-RPP-2003-00244, REVISION 0

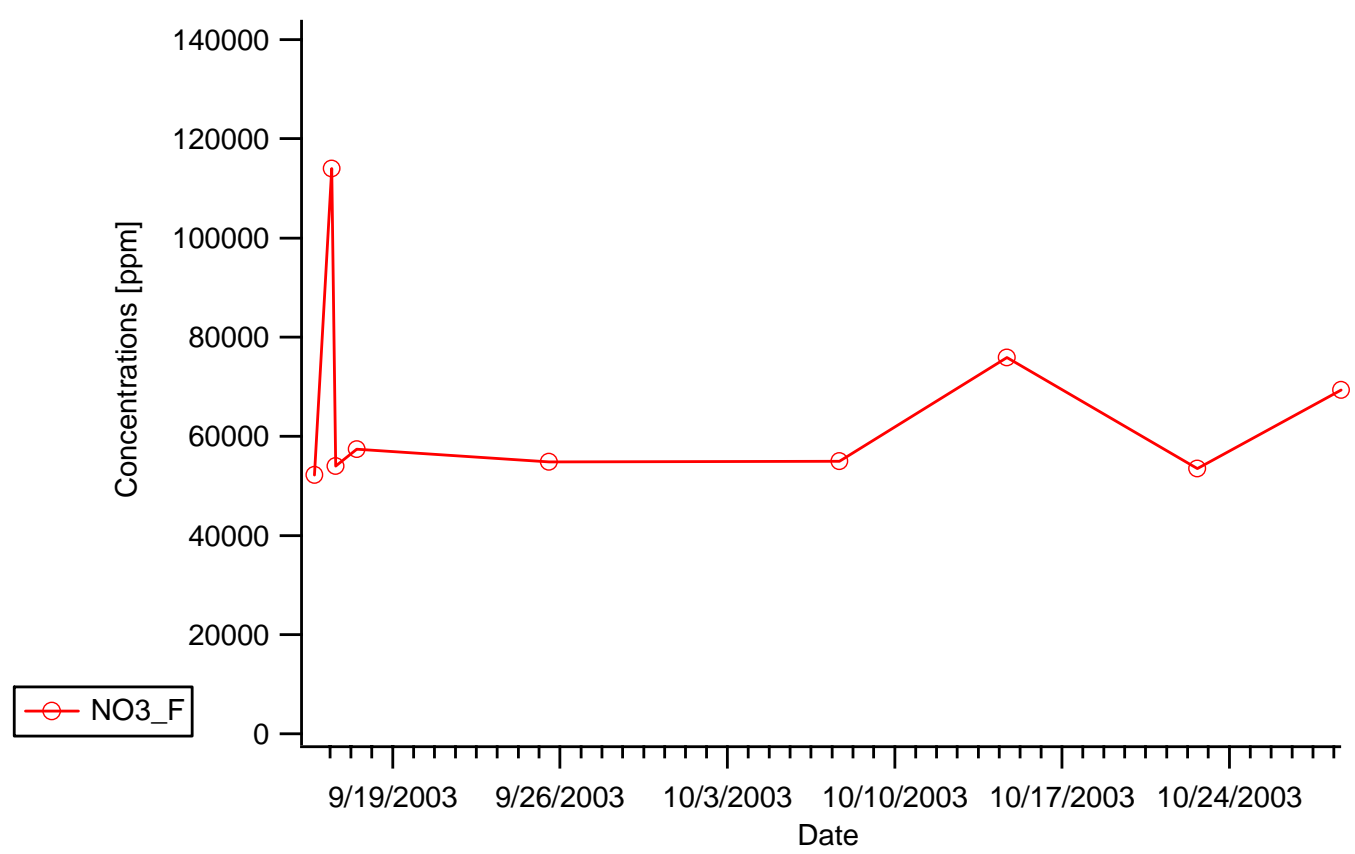

Figure 2-26. Evaporator Run 2 Feed Concentrations in ppm for Large Changing Anions

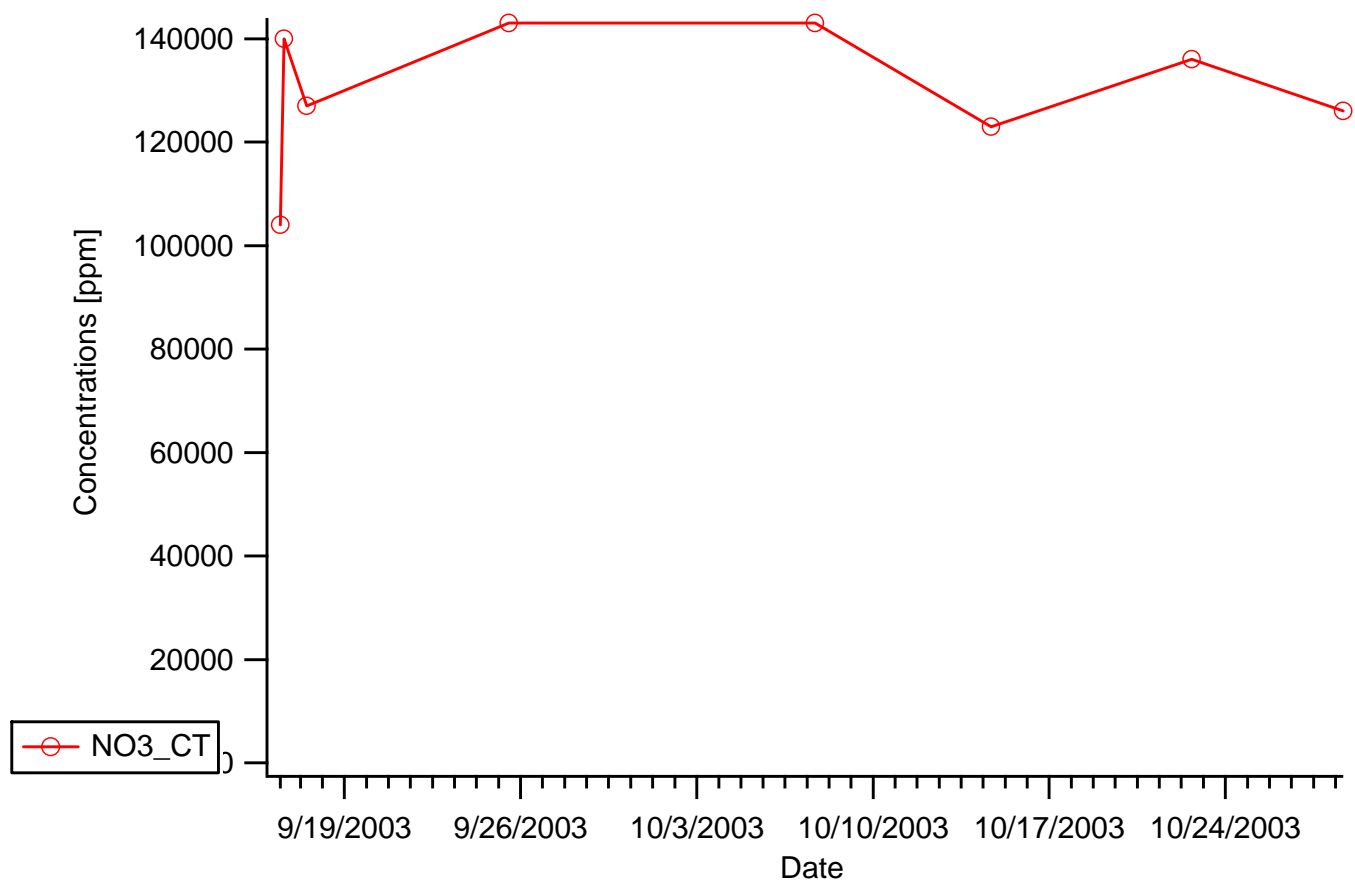

Figure 2-27. Evaporator Run 2 Concentrate Tank Concentrations in ppm for Large Changing Anions 
WSRC-TR-2003-00561, REVISION 0

SRT-RPP-2003-00244, REVISION 0

Table 2-6. Evaporator Run 2 Cation Analyses for Feed and Concentrate Tank (CT)

\begin{tabular}{|c|c|c|c|c|c|c|c|c|c|c|c|c|c|c|c|c|c|c|c|}
\hline Stream & $\begin{array}{c}\text { Lab } \\
\text { ID }\end{array}$ & $\begin{array}{l}\text { Date } \\
\text { Time }\end{array}$ & $\begin{array}{c}\text { Density } \\
\text { g/ml }\end{array}$ & pH & $\begin{array}{c}\text { Al } \\
\text { ppm }\end{array}$ & $\begin{array}{c}\text { As } \\
\text { ppm }\end{array}$ & $\begin{array}{c}\text { B } \\
\text { ppm }\end{array}$ & $\begin{array}{c}\text { Ba } \\
\text { ppm } \\
\end{array}$ & $\begin{array}{c}\text { Ca } \\
\text { ppm }\end{array}$ & $\begin{array}{c}\text { Cd } \\
\text { ppm }\end{array}$ & $\begin{array}{c}\text { Ce } \\
\text { ppm }\end{array}$ & $\begin{array}{c}\text { Co } \\
\text { ppm }\end{array}$ & $\begin{array}{c}\mathrm{Cr} \\
\mathrm{ppm}\end{array}$ & $\begin{array}{c}\mathrm{Cu} \\
\mathbf{p p m}\end{array}$ & $\begin{array}{c}\text { Fe } \\
\text { ppm }\end{array}$ & $\begin{array}{c}\mathrm{K} \\
\mathbf{p p m}\end{array}$ & $\begin{array}{c}\text { La } \\
\text { ppm }\end{array}$ & $\begin{array}{c}\mathbf{L i} \\
\mathbf{p p m} \\
\end{array}$ & $\begin{array}{c}\text { Mg } \\
\text { ppm }\end{array}$ \\
\hline Feed & $\begin{array}{c}03- \\
1861\end{array}$ & $\begin{array}{c}9 / 15 / 2003 \\
17: 30\end{array}$ & 1.10 & 12.9 & 4480 & $<1.00$ & 394 & $<0.010$ & 77.5 & 14.3 & 0.554 & $<0.100$ & 54.4 & 0.606 & 9.64 & 1110 & 0.383 & 10.6 & $<0.010$ \\
\hline Feed & $\begin{array}{c}03- \\
1864\end{array}$ & $\begin{array}{c}9 / 16 / 2003 \\
11: 00\end{array}$ & 1.36 & 13.4 & 8110 & $<1.00$ & 691 & 0.093 & 8.20 & 27.2 & 1.52 & $<0.100$ & 109 & 1.44 & 3.36 & 2310 & 1.07 & 113 & $<0.010$ \\
\hline Feed & $\begin{array}{c}03- \\
1820 \\
\end{array}$ & $\begin{array}{c}/ 16 / 2003 \\
14: 00\end{array}$ & 1.14 & 13.3 & 3400 & $<1.00$ & 361 & $<0.010$ & 78.5 & 14.4 & 0.546 & $<0.100$ & 62.2 & 0.88 & 12.3 & 1020 & 0.354 & 9.17 & $<0.010$ \\
\hline Feed & $\begin{array}{c}03- \\
1821 \\
\end{array}$ & $\begin{array}{c}9 / 17 / 2003 \\
12: 00 \\
\end{array}$ & 1.16 & 13.4 & 3340 & $<1.00$ & 340 & $<0.010$ & 72.6 & 15.0 & 0.983 & $<0.100$ & 62.9 & 1.03 & 6.72 & 1050 & 0.576 & 4.90 & $<0.010$ \\
\hline Feed & $\begin{array}{c}03- \\
1822\end{array}$ & $\begin{array}{c}9 / 25 / 2003 \\
13: 00\end{array}$ & 1.17 & 13.4 & 3740 & $<1.00$ & 356 & $<0.010$ & 113 & 15.4 & 1.14 & $<0.100$ & 66.8 & 1.33 & 7.22 & 1080 & 0.827 & 60.8 & $<0.010$ \\
\hline Feed & $\begin{array}{c}03- \\
1823\end{array}$ & $\begin{array}{c}10 / 7 / 2003 \\
16: 00\end{array}$ & 1.15 & 13.5 & 3800 & $<1.00$ & 361 & $<0.010$ & 114 & 15.3 & 1.06 & $<0.100$ & 66.7 & 1.33 & 10.9 & 1100 & 0.774 & 62.1 & $<0.010$ \\
\hline Feed & $\begin{array}{c}03- \\
1824 \\
\end{array}$ & $\begin{array}{c}10 / 14 / 200 \\
316: 00 \\
\end{array}$ & 1.23 & 13.7 & 5620 & $<1.00$ & 497 & $<0.010$ & 155 & 20.5 & 1.53 & $<0.100$ & 92.0 & 1.88 & 18.1 & 1570 & 1.05 & 89.5 & 4.35 \\
\hline Feed & $\begin{array}{c}03- \\
1825 \\
\end{array}$ & $\begin{array}{c}10 / 22 / 200 \\
316: 00 \\
\end{array}$ & 1.16 & 13.6 & 3940 & $<1.00$ & 365 & $<0.010$ & 106 & 14.9 & 1.06 & $<0.100$ & 67.1 & 1.37 & 14.5 & 1090 & 0.703 & 65.0 & $<0.010$ \\
\hline Feed & $\begin{array}{c}03- \\
1826\end{array}$ & $\begin{array}{c}10 / 28 / 200 \\
316: 00\end{array}$ & 1.20 & 13.9 & 4520 & $<1.00$ & 433 & $<0.010$ & 127 & 18.5 & 1.35 & $<0.100$ & 85.1 & 1.66 & 16.0 & 1250 & 0.826 & 81.7 & 3.30 \\
\hline $\mathrm{CT}$ & $\begin{array}{c}03- \\
1865\end{array}$ & $\begin{array}{c}9 / 16 / 2003 \\
11: 00\end{array}$ & 1.26 & 13.5 & 8630 & $<1.00$ & 790 & 0.039 & 177 & 26.5 & 1.40 & $<0.100$ & 106 & 1.10 & 10.5 & 2430 & 0.900 & 67.2 & 1.65 \\
\hline $\mathrm{CT}$ & $\begin{array}{c}03- \\
1827\end{array}$ & $\begin{array}{c}9 / 16 / 2003 \\
14: 00\end{array}$ & 1.52 & 13.5 & 10900 & $<1.00$ & 1160 & 0.218 & 287 & 32.2 & 2.04 & $<0.100$ & 167 & 3.35 & 13.2 & 3280 & 1.46 & 186.3 & 13.3 \\
\hline $\mathrm{CT}$ & $\begin{array}{c}03- \\
1828 \\
\end{array}$ & $\begin{array}{c}9 / 17 / 2003 \\
12: 00\end{array}$ & 1.61 & 13.5 & 10600 & $<1.00$ & 1010 & 0.195 & 275 & 33.6 & 2.26 & $<0.100$ & 168 & 3.47 & 20.1 & 3220 & 1.49 & 175.7 & 13.3 \\
\hline $\mathrm{CT}$ & $\begin{array}{c}03- \\
1829 \\
\end{array}$ & $\begin{array}{c}/ 25 / 2003 \\
13: 00 \\
\end{array}$ & 1.58 & 13.6 & 10400 & $<1.00$ & 938 & 0.166 & 266 & 32.5 & 2.78 & $<0.100$ & 167 & 3.52 & 11.7 & 3180 & 1.84 & 155.4 & 12.8 \\
\hline $\mathrm{CT}$ & $\begin{array}{c}03- \\
1830\end{array}$ & $\begin{array}{c}10 / 7 / 2003 \\
16: 00\end{array}$ & 1.43 & 13.7 & 4960 & $<1.00$ & 838 & 0.113 & 284 & 32.1 & 2.08 & $<0.100$ & 97.2 & 2.97 & 7.60 & 3150 & 1.72 & 116.3 & 12.1 \\
\hline $\mathrm{CT}$ & $\begin{array}{c}03- \\
1831\end{array}$ & $\begin{array}{c}10 / 14 / 200 \\
316: 00\end{array}$ & 1.47 & 13.6 & 8650 & $<1.00$ & 752 & 0.085 & 242 & 28.5 & 2.43 & $<0.100$ & 144 & 3.08 & 10.8 & 2530 & 1.67 & 147.2 & 11.7 \\
\hline $\mathrm{CT}$ & $\begin{array}{c}03- \\
1832\end{array}$ & $\begin{array}{c}10 / 22 / 200 \\
316: 00\end{array}$ & 1.51 & 13.8 & 11000 & $<1.00$ & 926 & 0.033 & 262 & 31.8 & 2.82 & $<0.100$ & 166 & 3.83 & 12.6 & 3270 & 1.76 & 169.6 & 15.3 \\
\hline $\mathrm{CT}$ & $\begin{array}{c}03- \\
1833 \\
\end{array}$ & $\begin{array}{c}10 / 28 / 200 \\
316: 00\end{array}$ & 1.49 & 13.7 & 9690 & $<1.00$ & 825 & $<0.010$ & 233 & 30.0 & 2.59 & $<0.100$ & 154 & 3.39 & 16.5 & 2900 & 1.57 & 157.0 & 14.5 \\
\hline
\end{tabular}


WSRC-TR-2003-00561, REVISION 0

SRT-RPP-2003-00244, REVISION 0

Table 2-6. Evaporator Run 2 Cation Analyses for Feed and Concentrate Tank (CT) - continued

\begin{tabular}{|c|c|c|c|c|c|c|c|c|c|c|c|c|c|c|c|c|c|c|c|}
\hline Stream & Date Time & $\begin{array}{c}\text { Mn } \\
\text { ppm }\end{array}$ & $\begin{array}{c}\text { Mo } \\
\text { ppm }\end{array}$ & $\begin{array}{c}\mathrm{Na} \\
\mathrm{ppm}\end{array}$ & $\begin{array}{c}\text { Nd } \\
\text { ppm }\end{array}$ & $\begin{array}{c}\mathrm{Ni} \\
\mathrm{ppm}\end{array}$ & $\begin{array}{c}\mathbf{P} \\
\mathbf{p p m}\end{array}$ & $\begin{array}{c}\text { Pb } \\
\text { ppm }\end{array}$ & $\begin{array}{c}\mathrm{S} \\
\mathbf{p p m}\end{array}$ & $\begin{array}{c}\mathrm{Si} \\
\mathbf{p p m}\end{array}$ & $\begin{array}{c}\text { Sn } \\
\text { ppm }\end{array}$ & $\begin{array}{c}\text { Sr } \\
\text { ppm }\end{array}$ & $\begin{array}{c}\text { Ti } \\
\text { ppm }\end{array}$ & $\begin{array}{c}\text { Tl } \\
\text { ppm }\end{array}$ & $\begin{array}{c}\text { V } \\
\text { ppm }\end{array}$ & $\begin{array}{c}\text { W } \\
\text { ppm }\end{array}$ & $\begin{array}{c}\mathrm{Zn} \\
\mathbf{p p m}\end{array}$ & $\begin{array}{c}\mathrm{Zr} \\
\text { ppm }\end{array}$ & $\begin{array}{c}\text { Na } \\
\text { Mol/L }\end{array}$ \\
\hline Feed & $\begin{array}{c}9 / 15 / 2003 \\
17: 30 \\
\end{array}$ & 0.077 & 11.7 & 56000 & 1.26 & 85.0 & 334 & 8.02 & 1110 & 43.8 & 19.7 & 6.93 & 0.23 & $<0.100$ & $<0.100$ & 44.5 & 40.5 & 0.708 & 2.7 \\
\hline Feed & $\begin{array}{c}9 / 16 / 2003 \\
11: 00 \\
\end{array}$ & 4.02 & 23.6 & 115000 & 3.39 & 149 & 492 & 18.4 & 2310 & 9.68 & 38.7 & 55.3 & 1.15 & $<0.100$ & $<0.100$ & 87.4 & 146 & 4.00 & 6.8 \\
\hline Feed & $\begin{array}{c}9 / 16 / 2003 \\
14: 00 \\
\end{array}$ & 0.009 & 12.5 & 60500 & 1.31 & 96 & 367 & 11.3 & 1839 & 57.0 & 20.7 & 7.89 & 0.121 & $<0.100$ & $<0.100$ & 46.9 & 42.9 & 0.550 & 3.0 \\
\hline Feed & $\begin{array}{c}9 / 17 / 2003 \\
12: 00 \\
\end{array}$ & 0.015 & 12.7 & 61700 & 1.70 & 97 & 350 & 9.7 & 1785 & 45.8 & 21.8 & 6.13 & 0.047 & $<0.100$ & $<0.100$ & 47.9 & 36.4 & 0.614 & 3.1 \\
\hline Feed & $\begin{array}{c}9 / 25 / 2003 \\
13: 00 \\
\end{array}$ & 2.97 & 13.1 & 64600 & 2.19 & 100 & 381 & 10.6 & 1614 & 62.2 & 23.3 & 28.1 & 0.580 & $<0.100$ & $<0.100$ & 49.2 & 74.0 & 1.56 & 3.3 \\
\hline Feed & $\begin{array}{c}10 / 7 / 2003 \\
16: 00 \\
\end{array}$ & 3.34 & 12.9 & 59600 & 2.09 & 99 & 383 & 10.9 & 1597 & 67.5 & 22.6 & 26.7 & 0.617 & $<0.100$ & $<0.100$ & 48.6 & 76.7 & 1.65 & 3.0 \\
\hline Feed & $\begin{array}{c}10 / 14 / 2003 \\
16: 00 \\
\end{array}$ & 4.65 & 17.3 & 83200 & 2.86 & 137 & 530 & 14.4 & 2156 & 98.2 & 30.2 & 28.6 & 0.780 & $<0.100$ & $<0.100$ & 63.1 & 108 & 2.40 & 4.5 \\
\hline Feed & $\begin{array}{c}10 / 22 / 2003 \\
16: 00\end{array}$ & 3.23 & 12.7 & 58200 & 1.90 & 98 & 371 & 10.6 & 1550 & 69.6 & 22.7 & 12.9 & 0.574 & $<0.100$ & $<0.100$ & 48.3 & 74.6 & 1.46 & 2.9 \\
\hline Feed & $\begin{array}{c}10 / 28 / 2003 \\
16: 00\end{array}$ & 4.33 & 15.6 & 71700 & 2.28 & 125 & 469 & 13.0 & 1525 & 83.9 & 28.0 & 12.5 & 0.905 & $<0.100$ & $<0.100$ & 57.1 & 96.0 & 2.38 & 3.7 \\
\hline $\mathrm{CT}$ & $\begin{array}{c}9 / 16 / 2003 \\
11: 00\end{array}$ & 2.74 & 23.0 & 143000 & 2.94 & 146 & 457 & 17.2 & 2430 & 96.2 & 37.7 & 46.2 & 0.582 & $<0.100$ & $<0.100$ & 84.6 & 118 & 1.98 & 7.8 \\
\hline $\mathrm{CT}$ & $\begin{array}{c}9 / 16 / 2003 \\
14: 00 \\
\end{array}$ & 5.59 & 28.5 & 188000 & 4.58 & 249 & 551 & 25.6 & 4700 & 142 & 46.7 & 84.8 & 1.01 & $<0.100$ & $<0.100$ & 101 & 197 & 3.52 & 12.4 \\
\hline $\mathrm{CT}$ & $\begin{array}{c}9 / 17 / 2003 \\
12: 00 \\
\end{array}$ & 5.90 & 28.8 & 178000 & 4.62 & 248 & 1079 & 26.0 & 3711 & 147 & 48.6 & 73.9 & 0.970 & $<0.100$ & $<0.100$ & 94.6 & 197 & 3.50 & 12.5 \\
\hline $\mathrm{CT}$ & $\begin{array}{c}9 / 25 / 2003 \\
13: 00 \\
\end{array}$ & 7.05 & 28.6 & 169000 & 5.08 & 246 & 917 & 22.7 & 3333 & 135 & 47.4 & 71.5 & 0.956 & $<0.100$ & $<0.100$ & 106 & 178 & 3.50 & 11.6 \\
\hline $\mathrm{CT}$ & $\begin{array}{c}10 / 7 / 2003 \\
16: 00 \\
\end{array}$ & 5.25 & 12.3 & 174000 & 4.65 & 216 & 54.9 & 9.5 & 3551 & 69.0 & 27.6 & 73.7 & 0.052 & $<0.100$ & $<0.100$ & 39.3 & 178 & 1.91 & 10.8 \\
\hline $\mathrm{CT}$ & $\begin{array}{c}10 / 14 / 2003 \\
16: 00 \\
\end{array}$ & 7.43 & 25.2 & 152000 & 4.54 & 213 & 461 & 20.2 & 3213 & 127 & 42.6 & 55.1 & 0.976 & $<0.100$ & $<0.100$ & 93.3 & 162 & 3.18 & 9.7 \\
\hline $\mathrm{CT}$ & $\begin{array}{c}10 / 22 / 2003 \\
16: 00 \\
\end{array}$ & 8.12 & 28.1 & 179000 & 4.91 & 244 & 766 & 22.3 & 3676 & 139 & 47.3 & 33.2 & 1.17 & $<0.100$ & $<0.100$ & 101 & 181 & 3.96 & 11.8 \\
\hline $\mathrm{CT}$ & $\begin{array}{c}10 / 28 / 2003 \\
16: 00\end{array}$ & 7.65 & 26.5 & 162000 & 4.35 & 228 & 535 & 20.9 & 3200 & 144 & 44.3 & 23.5 & 0.997 & $<0.100$ & $<0.100$ & 97.8 & 171 & 3.37 & 10.5 \\
\hline
\end{tabular}


WSRC-TR-2003-00561, REVISION 0

SRT-RPP-2003-00244, REVISION 0

Table 2-7. Evaporator Run 2 Cation Analyses for Primary (PCT) and Secondary (SCT) Condensate Tanks

\begin{tabular}{|c|c|c|c|c|c|c|c|c|c|c|c|c|c|c|c|c|c|c|c|}
\hline Stream & Lab ID & Date Time & $\begin{array}{l}\text { Den. } \\
\text { g/ml }\end{array}$ & pH & $\begin{array}{c}\text { Al } \\
\text { ppm }\end{array}$ & $\begin{array}{c}\text { As } \\
\text { ppm }\end{array}$ & $\begin{array}{r}\text { B } \\
\text { ppm } \\
\end{array}$ & $\begin{array}{c}\text { Ba } \\
\text { ppm } \\
\end{array}$ & $\begin{array}{r}\text { Ca } \\
\text { ppm } \\
\end{array}$ & $\begin{array}{c}\text { Cd } \\
\text { ppm } \\
\end{array}$ & $\begin{array}{c}\mathrm{Ce} \\
\mathrm{ppm}\end{array}$ & $\begin{array}{c}\text { Co } \\
\text { ppm }\end{array}$ & $\begin{array}{r}\mathrm{Cr} \\
\mathrm{ppm} \\
\end{array}$ & $\begin{array}{r}\mathrm{Cu} \\
\mathbf{p p m} \\
\end{array}$ & $\begin{array}{c}\mathbf{F e} \\
\mathrm{ppm} \\
\end{array}$ & $\begin{array}{c}\mathrm{K} \\
\mathbf{p p m} \\
\end{array}$ & $\begin{array}{c}\mathbf{L a} \\
\mathbf{p p m}\end{array}$ & $\begin{array}{c}\mathbf{L i} \\
\mathbf{p p m} \\
\end{array}$ & $\begin{array}{r}\text { Mg } \\
\text { ppm }\end{array}$ \\
\hline PCT & 03-1862 & 9/15/03 17:30 & 1.00 & 10.4 & 131 & $<0.100$ & 4.89 & $<0.001$ & 1.52 & $<0.010$ & $<0.010$ & $<0.010$ & $<0.010$ & $<0.001$ & 1.94 & 1.00 & $<0.001$ & $<0.100$ & $<0.001$ \\
\hline $\mathrm{PCT}$ & 03-1866 & 9/16/03 11:00 & 1.01 & 11.6 & 1.69 & $<0.100$ & 2.68 & $<0.001$ & 1.48 & $<0.010$ & $<0.010$ & $<0.010$ & $<0.010$ & $<0.001$ & 2.95 & 1.98 & $<0.001$ & $<0.100$ & $<0.001$ \\
\hline PCT & 03-1834 & 9/16/03 14:00 & 1.01 & 10.8 & 5.16 & $<0.100$ & 4.76 & $<0.001$ & 1.25 & $<0.010$ & $<0.010$ & $<0.010$ & $<0.010$ & $<0.001$ & 1.23 & 0.668 & $<0.001$ & $<0.100$ & $<0.001$ \\
\hline $\mathrm{PCT}$ & 03-1835 & 9/17/03 12:00 & 1.01 & 11.1 & 2.05 & $<0.100$ & 3.75 & $<0.001$ & 1.36 & $<0.010$ & $<0.010$ & $<0.010$ & $<0.010$ & $<0.001$ & 2.24 & 0.289 & $<0.001$ & $<0.100$ & $<0.001$ \\
\hline $\mathrm{PCT}$ & 03-1836 & 9/25/03 13:00 & 1.01 & 10.7 & 1.55 & $<0.100$ & 3.11 & $<0.001$ & 1.13 & $<0.010$ & $<0.010$ & $<0.010$ & $<0.010$ & $<0.001$ & 0.736 & 0.302 & $<0.001$ & $<0.100$ & $<0.001$ \\
\hline $\mathrm{PCT}$ & 03-1837 & 10/7/03 16:00 & 1.01 & 10.2 & 1.60 & $<0.100$ & 3.59 & $<0.001$ & 1.17 & $<0.010$ & $<0.010$ & $<0.010$ & $<0.010$ & $<0.001$ & 0.925 & 0.178 & $<0.001$ & $<0.100$ & $<0.001$ \\
\hline PCT & 03-1838 & 10/14/03 16:00 & 1.02 & 9.89 & 1.82 & $<0.100$ & 3.75 & $<0.001$ & 1.21 & $<0.010$ & $<0.010$ & $<0.010$ & $<0.010$ & $<0.001$ & 1.33 & 0.150 & $<0.001$ & $<0.100$ & $<0.001$ \\
\hline PCT & 03-1839 & 10/22/03 16:00 & 1.00 & 9.95 & 1.64 & $<0.100$ & 3.17 & $<0.001$ & 1.48 & $<0.010$ & $<0.010$ & $<0.010$ & $<0.010$ & $<0.001$ & 1.21 & 1.390 & $<0.001$ & $<0.100$ & $<0.001$ \\
\hline $\mathrm{PCT}$ & 03-1840 & 10/28/03 16:00 & 1.01 & 9.56 & 1.02 & $<0.100$ & 3.67 & $<0.001$ & 1.21 & $<0.010$ & $<0.010$ & $<0.010$ & $<0.010$ & $<0.001$ & 0.886 & 0.255 & $<0.001$ & $<0.100$ & $<0.001$ \\
\hline SCT & 03-1863 & 9/15/03 17:30 & 1.01 & 11.0 & 23.9 & $<0.100$ & 3.10 & $<0.001$ & 3.01 & $<0.010$ & $<0.010$ & $<0.010$ & $<0.010$ & $<0.001$ & 1.38 & 0.934 & $<0.001$ & $<0.100$ & $<0.001$ \\
\hline SCT & 03-1867 & 9/16/03 11:00 & 1.01 & 11.9 & 6.55 & $<0.100$ & 3.22 & $<0.001$ & 1.48 & $<0.010$ & $<0.010$ & $<0.010$ & $<0.010$ & $<0.001$ & 2.99 & 0.101 & $<0.001$ & $<0.100$ & $<0.001$ \\
\hline SCT & 03-1841 & 9/16/03 14:00 & 1.00 & 11.4 & 2.95 & $<0.100$ & 5.58 & $<0.001$ & 1.70 & $<0.010$ & $<0.010$ & $<0.010$ & $<0.010$ & $<0.001$ & 1.76 & 0.199 & $<0.001$ & $<0.100$ & $<0.001$ \\
\hline SCT & 03-1842 & 9/17/03 12:00 & 1.00 & 11.2 & 2.08 & $<0.100$ & 3.87 & $<0.001$ & 1.83 & $<0.010$ & $<0.010$ & $<0.010$ & $<0.010$ & $<0.001$ & 2.47 & 0.154 & $<0.001$ & $<0.100$ & $<0.001$ \\
\hline SCT & 03-1843 & 9/25/03 13:00 & 1.00 & 10.4 & 1.17 & $<0.100$ & 3.96 & $<0.001$ & 1.62 & $<0.010$ & $<0.010$ & $<0.010$ & $<0.010$ & $<0.001$ & 0.845 & 0.267 & $<0.001$ & $<0.100$ & $<0.001$ \\
\hline SCT & 03-1844 & 10/7/03 16:00 & 1.00 & 11.2 & 3.21 & $<0.100$ & 3.90 & $<0.001$ & 3.43 & $<0.010$ & $<0.010$ & $<0.010$ & $<0.010$ & $<0.001$ & 2.82 & 0.131 & $<0.001$ & $<0.100$ & $<0.001$ \\
\hline SCT & 03-1845 & 10/14/03 16:00 & 1.00 & 10.6 & 1.43 & $<0.100$ & 3.72 & $<0.001$ & 1.56 & $<0.010$ & $<0.010$ & $<0.010$ & $<0.010$ & $<0.001$ & 2.01 & 0.148 & $<0.001$ & $<0.100$ & $<0.001$ \\
\hline $\mathrm{SCT}$ & 03-1846 & 10/22/03 16:00 & 1.01 & 10.2 & 1.06 & $<0.100$ & 3.44 & $<0.001$ & 1.20 & $<0.010$ & $<0.010$ & $<0.010$ & $<0.010$ & $<0.001$ & 0.708 & 0.56 & $<0.001$ & $<0.100$ & $<0.001$ \\
\hline SCT & 03-1847 & 10/28/03 16:00 & 1.01 & 9.65 & 0.84 & $<0.100$ & 3.53 & $<0.001$ & 1.81 & $<0.010$ & $<0.010$ & $<0.010$ & $<0.010$ & $<0.001$ & 1.95 & 0.501 & $<0.001$ & $<0.100$ & $<0.001$ \\
\hline KDL & 03-1848 & 9/16/03 14:00 & 1.01 & 9.31 & 1.37 & $<0.100$ & 4.83 & $<0.001$ & 3.24 & $<0.010$ & $<0.010$ & $<0.010$ & $<0.010$ & 1.89 & 14.6 & 0.546 & $<0.001$ & $<0.100$ & $<0.001$ \\
\hline $\mathrm{KDL}$ & 03-1849 & 9/25/03 13:00 & 1.02 & 9.77 & 1.39 & $<0.100$ & 3.03 & $<0.001$ & 2.20 & $<0.010$ & $<0.010$ & $<0.010$ & $<0.010$ & 2.11 & 2.39 & 0.198 & $<0.001$ & $<0.100$ & $<0.001$ \\
\hline $\mathrm{KDL}$ & 03-1850 & 10/7/03 16:00 & 1.00 & 10.9 & 2.06 & $<0.100$ & 3.57 & $<0.001$ & 6.76 & $<0.010$ & $<0.010$ & $<0.010$ & $<0.010$ & $<0.001$ & 1.99 & 0.503 & $<0.001$ & $<0.100$ & $<0.001$ \\
\hline KDL & 03-1851 & 10/14/03 16:00 & 1.01 & 9.61 & 1.49 & $<0.100$ & 3.42 & $<0.001$ & 2.37 & $<0.010$ & $<0.010$ & $<0.010$ & $<0.010$ & $<0.001$ & 0.981 & 0.346 & $<0.001$ & $<0.100$ & $<0.001$ \\
\hline KDL & 03-1852 & 10/22/03 16:00 & 1.01 & 8.27 & 1.66 & $<0.100$ & 3.85 & $<0.001$ & 2.38 & $<0.010$ & $<0.010$ & $<0.010$ & $<0.010$ & $<0.001$ & 1.62 & 0.636 & $<0.001$ & $<0.100$ & $<0.001$ \\
\hline KDL & 03-1853 & 10/28/03 16:00 & 1.01 & 11.4 & 1.16 & $<0.100$ & 3.21 & $<0.001$ & 2.14 & $<0.010$ & $<0.010$ & $<0.010$ & $<0.010$ & $<0.001$ & 0.636 & 5.69 & $<0.001$ & $<0.100$ & $<0.001$ \\
\hline
\end{tabular}


WSRC-TR-2003-00561, REVISION 0

SRT-RPP-2003-00244, REVISION 0

Table 2-7. Evaporator Run 2 Cation Analyses for Primary (PCT) and Secondary (SCT) Condensate Tanks - continued

\begin{tabular}{|c|c|c|c|c|c|c|c|c|c|c|c|c|c|c|c|c|c|c|c|}
\hline Stream & Date Time & $\begin{array}{c}\text { Mn } \\
\text { ppm }\end{array}$ & $\begin{array}{c}\text { Mo } \\
\text { ppm }\end{array}$ & $\begin{array}{c}\mathrm{Na} \\
\mathrm{ppm}\end{array}$ & $\begin{array}{c}\text { Nd } \\
\text { ppm }\end{array}$ & $\begin{array}{c}\mathrm{Ni} \\
\mathbf{p p m}\end{array}$ & $\begin{array}{c}\mathbf{P} \\
\mathbf{p p m} \\
\end{array}$ & $\begin{array}{c}\mathbf{P b} \\
\mathbf{p p m}\end{array}$ & $\begin{array}{c}\mathrm{S} \\
\mathrm{ppm} \\
\end{array}$ & $\begin{array}{c}\mathrm{Si} \\
\mathrm{ppm} \\
\end{array}$ & $\begin{array}{c}\text { Sn } \\
\text { ppm }\end{array}$ & $\begin{array}{c}\text { Sr } \\
\text { ppm }\end{array}$ & $\begin{array}{c}\mathrm{Ti} \\
\mathbf{p p m} \\
\end{array}$ & $\begin{array}{c}\text { Tl } \\
\text { ppm } \\
\end{array}$ & $\begin{array}{c}\mathrm{V} \\
\mathrm{ppm} \\
\end{array}$ & $\begin{array}{c}\mathrm{W} \\
\mathrm{ppm} \\
\end{array}$ & $\begin{array}{c}\mathrm{Zn} \\
\mathbf{p p m} \\
\end{array}$ & $\begin{array}{c}\mathrm{Zr} \\
\mathbf{p p m} \\
\end{array}$ & $\begin{array}{c}\mathrm{Na} \\
\mathrm{Mol} / \mathrm{L} \\
\end{array}$ \\
\hline PCT & 9/15/2003 17:30 & $<0.001$ & $<0.010$ & 1060 & $<0.002$ & $<0.030$ & $<0.100$ & $<0.050$ & 0.46 & 1.95 & $<0.050$ & 0.686 & $<0.001$ & $<0.010$ & $<0.010$ & 2.77 & $<0.001$ & $<0.001$ & 0.0 \\
\hline PCT & 9/16/2003 11:00 & $<0.001$ & $<0.010$ & 1410 & $<0.002$ & $<0.030$ & $<0.100$ & $<0.050$ & 1.87 & 3.15 & $<0.050$ & 0.687 & $<0.001$ & $<0.010$ & $<0.010$ & 0.326 & $<0.001$ & $<0.001$ & 0.1 \\
\hline PCT & 9/16/2003 14:00 & $<0.001$ & $<0.010$ & 31.6 & $<0.002$ & $<0.030$ & 0.639 & $<0.050$ & 0.092 & 7.53 & $<0.050$ & $<0.100$ & $<0.001$ & $<0.010$ & $<0.010$ & 0.174 & $<0.001$ & $<0.001$ & 0.0 \\
\hline PCT & 9/17/2003 12:00 & $<0.001$ & $<0.010$ & 11.8 & $<0.002$ & $<0.030$ & 0.132 & $<0.050$ & 0.156 & 11.8 & $<0.050$ & $<0.100$ & $<0.001$ & $<0.010$ & $<0.010$ & 0.041 & $<0.001$ & $<0.001$ & 0.0 \\
\hline PCT & 9/25/2003 13:00 & $<0.001$ & $<0.010$ & 14.4 & $<0.002$ & $<0.030$ & $<0.100$ & $<0.050$ & 0.113 & 5.53 & $<0.050$ & $<0.100$ & $<0.001$ & $<0.010$ & $<0.010$ & 0.024 & $<0.001$ & $<0.001$ & 0.0 \\
\hline PCT & 10/14/2003 16:00 & $<0.001$ & $<0.010$ & 15.6 & $<0.002$ & $<0.030$ & $<0.100$ & $<0.050$ & 0.092 & 8.73 & $<0.050$ & $<0.100$ & $<0.001$ & $<0.010$ & $<0.010$ & 0.020 & $<0.001$ & $<0.001$ & 0.0 \\
\hline PCT & 10/22/2003 16:00 & $<0.001$ & $<0.010$ & 10.3 & $<0.002$ & $<0.030$ & $<0.100$ & $<0.050$ & 0.162 & 6.18 & $<0.050$ & $<0.100$ & $<0.001$ & $<0.010$ & $<0.010$ & 0.019 & $<0.001$ & $<0.001$ & 0.0 \\
\hline PCT & 10/28/2003 16:00 & $<0.001$ & $<0.010$ & 7.66 & $<0.002$ & $<0.030$ & $<0.100$ & $<0.050$ & 0.056 & 7.47 & $<0.050$ & $<0.100$ & $<0.001$ & $<0.010$ & $<0.010$ & 0.019 & $<0.001$ & $<0.001$ & 0.0 \\
\hline SCT & 9/15/2003 17:30 & $<0.001$ & $<0.010$ & 1570 & $<0.002$ & $<0.030$ & $<0.100$ & $<0.050$ & 0.415 & 2.02 & $<0.050$ & 0.690 & $<0.001$ & $<0.010$ & $<0.010$ & 0.384 & $<0.001$ & $<0.001$ & 0.1 \\
\hline SCT & 9/16/2003 11:00 & $<0.001$ & $<0.010$ & 1260 & $<0.002$ & $<0.030$ & $<0.100$ & $<0.050$ & 0.086 & 4.76 & $<0.050$ & $<0.100$ & $<0.001$ & $<0.010$ & $<0.010$ & 0.031 & $<0.001$ & $<0.001$ & 0.1 \\
\hline SCT & 9/16/2003 14:00 & $<0.001$ & $<0.010$ & 7.03 & $<0.002$ & $<0.030$ & $<0.100$ & $<0.050$ & 0.130 & 8.10 & $<0.050$ & $<0.100$ & $<0.001$ & $<0.010$ & $<0.010$ & 0.204 & $<0.001$ & $<0.001$ & 0.0 \\
\hline SCT & 9/25/2003 13:00 & $<0.001$ & $<0.010$ & 32.7 & $<0.002$ & $<0.030$ & $<0.100$ & $<0.050$ & 0.162 & 8.14 & $<0.050$ & $<0.100$ & $<0.001$ & $<0.010$ & $<0.010$ & 0.021 & $<0.001$ & $<0.001$ & 0.0 \\
\hline SCT & 10/7/2003 16:00 & $<0.001$ & $<0.010$ & 13.5 & $<0.002$ & $<0.030$ & $<0.100$ & $<0.050$ & 0.119 & 10.3 & $<0.050$ & $<0.100$ & $<0.001$ & $<0.010$ & $<0.010$ & 0.022 & $<0.001$ & $<0.001$ & 0.0 \\
\hline SCT & 10/14/2003 16:00 & $<0.001$ & $<0.010$ & 8.05 & $<0.002$ & $<0.030$ & $<0.100$ & $<0.050$ & 0.103 & 8.14 & $<0.050$ & $<0.100$ & $<0.001$ & $<0.010$ & $<0.010$ & 0.018 & $<0.001$ & $<0.001$ & 0.0 \\
\hline SCT & 10/22/2003 16:00 & $<0.001$ & $<0.010$ & 13.6 & $<0.002$ & $<0.030$ & $<0.100$ & $<0.050$ & 0.152 & 7.55 & $<0.050$ & $<0.100$ & $<0.001$ & $<0.010$ & $<0.010$ & 0.020 & $<0.001$ & $<0.001$ & 0.0 \\
\hline SCT & 10/28/2003 16:00 & $<0.001$ & $<0.010$ & 24.0 & $<0.002$ & $<0.030$ & $<0.100$ & $<0.050$ & 0.366 & 10.3 & $<0.050$ & $<0.100$ & $<0.001$ & $<0.010$ & $<0.010$ & 0.018 & $<0.001$ & $<0.001$ & 0.0 \\
\hline KDL & 9/16/2003 14:00 & $<0.001$ & 0.156 & 10.6 & $<0.002$ & $<0.030$ & $<0.100$ & $<0.050$ & 0.842 & 6.97 & $<0.050$ & $<0.100$ & $<0.001$ & $<0.010$ & $<0.010$ & 0.342 & $<0.001$ & $<0.001$ & 0.0 \\
\hline KDL & 9/25/2003 13:00 & $<0.001$ & 0.100 & 7.57 & $<0.002$ & $<0.030$ & $<0.100$ & $<0.050$ & 0.379 & 5.53 & $<0.050$ & $<0.100$ & $<0.001$ & $<0.010$ & $<0.010$ & 0.114 & $<0.001$ & $<0.001$ & 0.0 \\
\hline KDL & 10/7/2003 16:00 & $<0.001$ & $<0.010$ & 14.6 & $<0.002$ & $<0.030$ & $<0.100$ & $<0.050$ & 0.133 & 7.49 & $<0.050$ & $<0.100$ & $<0.001$ & $<0.010$ & $<0.010$ & 0.043 & $<0.001$ & $<0.001$ & 0.0 \\
\hline KDL & 10/14/2003 16:00 & $<0.001$ & $<0.010$ & 22.4 & $<0.002$ & $<0.030$ & $<0.100$ & $<0.050$ & 0.281 & 7.59 & $<0.050$ & $<0.100$ & $<0.001$ & $<0.010$ & $<0.010$ & 0.028 & $<0.001$ & $<0.001$ & 0.0 \\
\hline $\mathrm{KDL}$ & 10/22/2003 16:00 & $<0.001$ & $<0.010$ & 30.6 & $<0.002$ & $<0.030$ & $<0.100$ & $<0.050$ & 0.526 & 11.1 & $<0.050$ & $<0.100$ & $<0.001$ & $<0.010$ & $<0.010$ & 0.035 & $<0.001$ & $<0.001$ & 0.0 \\
\hline KDL & 10/28/2003 16:00 & $<0.001$ & $<0.010$ & 203 & $<0.002$ & $<0.030$ & $<0.100$ & $<0.050$ & 4.02 & 55.9 & $<0.050$ & $<0.100$ & $<0.001$ & $<0.010$ & $<0.010$ & 0.024 & $<0.001$ & $<0.001$ & 0.0 \\
\hline
\end{tabular}


WSRC-TR-2003-00561, REVISION 0

SRT-RPP-2003-00244, REVISION 0

Table 2-8. Evaporator Run 2 Anion Analyses

\begin{tabular}{|c|c|c|c|c|c|c|c|c|c|}
\hline Stream & Lab ID & Process Date & $\begin{array}{c}\text { HCOO } \\
\text { ppm }\end{array}$ & $\begin{array}{c}\mathrm{Cl} \\
\text { ppm }\end{array}$ & $\begin{array}{l}\text { NO2 } \\
\text { ppm }\end{array}$ & $\begin{array}{l}\text { NO3 } \\
\text { ppm }\end{array}$ & $\begin{array}{l}\text { PO4 } \\
\text { ppm }\end{array}$ & $\begin{array}{l}\text { SO4 } \\
\text { ppm }\end{array}$ & $\begin{array}{l}\mathrm{C2O4} \\
\text { ppm }\end{array}$ \\
\hline $\mathrm{CT}$ & 03-1865 & 9/16/2003 11:00 & 4220 & 7790 & 34100 & 104000 & 1480 & 7060 & $<1000$ \\
\hline CT & 03-1827 & 9/16/2003 14:38 & 6400 & 10900 & 57900 & 140000 & 1070 & 12100 & $<1000$ \\
\hline $\mathrm{CT}$ & 03-1828 & 9/17/2003 12:00 & 6760 & 10600 & 51200 & 127000 & 1430 & 10000 & $<1000$ \\
\hline CT & 03-1829 & 9/25/2003 13:00 & 5470 & 9630 & 56400 & 143000 & 1970 & 9620 & 1200 \\
\hline $\mathrm{CT}$ & 03-1830 & 10/7/2003 16:40 & 5440 & 9870 & 54100 & 143000 & 2110 & 11400 & 1310 \\
\hline CT & 03-1831 & 10/14/2003 16:40 & 4450 & 8000 & 52200 & 123000 & 1320 & 9800 & 1100 \\
\hline CT & 03-1832 & 10/22/2003 16:00 & 5280 & 9460 & 54800 & 136000 & 1570 & 9590 & 1130 \\
\hline CT & 03-1833 & 10/28/2003 16:20 & 5110 & 9050 & 54700 & 126000 & 1480 & 8750 & 853 \\
\hline Feed & 03-1861 & 9/15/2003 17:30 & 1850 & 3790 & 18300 & 52200 & 1500 & 5200 & $<1000$ \\
\hline Feed & 03-1864 & 9/16/2003 11:00 & 4180 & 7960 & 42900 & 114000 & 1280 & 9340 & $<1000$ \\
\hline Feed & 03-1820 & 9/16/2003 14:38 & 2020 & 3930 & 20100 & 54000 & $<1000$ & 5350 & $<1000$ \\
\hline Feed & 03-1821 & 9/17/2003 12:00 & 1950 & 3520 & 19900 & 57400 & 1250 & 4840 & $<1000$ \\
\hline Feed & $03-1822$ & 9/25/2003 13:00 & 1970 & 3600 & 21100 & 54800 & 1450 & 4650 & $<1000$ \\
\hline Feed & 03-1823 & 10/7/2003 16:40 & 1980 & 3680 & 19600 & 55000 & 1420 & 4350 & $<1000$ \\
\hline Feed & 03-1824 & 10/14/2003 16:40 & 2930 & 5110 & 26600 & 75900 & 1670 & 5970 & $<1000$ \\
\hline Feed & $03-1825$ & 10/22/2003 16:00 & 2080 & 3660 & 19700 & 53500 & 1330 & 4170 & $<1000$ \\
\hline Feed & 03-1826 & 10/28/2003 16:20 & 2560 & 4740 & 25000 & 69300 & 1500 & 4570 & $<1000$ \\
\hline KDL & 03-1848 & 9/16/2003 14:38 & $<100$ & $<100$ & $<100$ & $<100$ & $<100$ & $<100$ & $<100$ \\
\hline KDL & 03-1849 & 9/25/2003 13:00 & $<100$ & $<100$ & $<100$ & $<100$ & $<100$ & $<100$ & $<100$ \\
\hline KDL & 03-1850 & 10/7/2003 16:40 & $<100$ & $<100$ & $<100$ & $<100$ & $<100$ & $<100$ & $<100$ \\
\hline KDL & 03-1851 & 10/14/2003 16:40 & $<100$ & $<100$ & $<100$ & $<100$ & $<100$ & $<100$ & $<100$ \\
\hline KDL & 03-1852 & $10 / 22 / 200316: 00$ & $<100$ & $<100$ & $<100$ & $<100$ & $<100$ & $<100$ & $<100$ \\
\hline KDL & 03-1853 & 10/28/2003 16:20 & $<100$ & $<100$ & $<100$ & $<100$ & $<100$ & $<100$ & $<100$ \\
\hline PCT & 03-1862 & 9/15/2003 17:30 & $<100$ & $<100$ & $<100$ & $<100$ & $<100$ & $<100$ & $<100$ \\
\hline PCT & 03-1866 & 9/16/2003 11:00 & $<100$ & $<100$ & $<100$ & $<100$ & $<100$ & $<100$ & $<100$ \\
\hline PCT & 03-1834 & 9/16/2003 14:38 & $<100$ & $<100$ & $<100$ & $<100$ & $<100$ & $<100$ & $<100$ \\
\hline PCT & 03-1835 & 9/17/2003 12:00 & $<100$ & $<100$ & $<100$ & $<100$ & $<100$ & $<100$ & $<100$ \\
\hline PCT & 03-1836 & 9/25/2003 13:00 & $<100$ & $<100$ & $<100$ & $<100$ & $<100$ & $<100$ & $<100$ \\
\hline PCT & 03-1837 & 10/7/2003 16:40 & $<100$ & $<100$ & $<100$ & $<100$ & $<100$ & $<100$ & $<100$ \\
\hline PCT & 03-1838 & 10/14/2003 16:40 & $<100$ & $<100$ & $<100$ & $<100$ & $<100$ & $<100$ & $<100$ \\
\hline PCT & 03-1839 & 10/22/2003 16:00 & $<100$ & $<100$ & $<100$ & $<100$ & $<100$ & $<100$ & $<100$ \\
\hline PCT & 03-1840 & 10/28/2003 16:20 & $<100$ & $<100$ & $<100$ & $<100$ & $<100$ & $<100$ & $<100$ \\
\hline SCT & 03-1863 & 9/15/2003 17:30 & $<100$ & $<100$ & $<100$ & $<100$ & $<100$ & $<100$ & $<100$ \\
\hline SCT & 03-1867 & 9/16/2003 11:00 & $<100$ & $<100$ & $<100$ & $<100$ & $<100$ & $<100$ & $<100$ \\
\hline SCT & 03-1841 & 9/16/2003 14:38 & $<100$ & $<100$ & $<100$ & $<100$ & $<100$ & $<100$ & $<100$ \\
\hline SCT & 03-1842 & 9/17/2003 12:00 & $<100$ & $<100$ & $<100$ & $<100$ & $<100$ & $<100$ & $<100$ \\
\hline SCT & 03-1843 & 9/25/2003 13:00 & $<100$ & $<100$ & $<100$ & $<100$ & $<100$ & $<100$ & $<100$ \\
\hline SCT & 03-1844 & 10/7/2003 16:40 & $<100$ & $<100$ & $<100$ & $<100$ & $<100$ & $<100$ & $<100$ \\
\hline SCT & 03-1845 & 10/14/2003 16:40 & $<100$ & $<100$ & $<100$ & $<100$ & $<100$ & $<100$ & $<100$ \\
\hline SCT & 03-1846 & $10 / 22 / 200316: 00$ & $<100$ & $<100$ & $<100$ & $<100$ & $<100$ & $<100$ & $<100$ \\
\hline SCT & 03-1847 & 10/28/2003 16:20 & $<100$ & $<100$ & $<100$ & $<100$ & $<100$ & $<100$ & $<100$ \\
\hline
\end{tabular}




\subsubsection{Organic Partitioning}

During Test 2, the evaporator pot was spiked with organics to examine the partitioning of volatile and semi-volatile organics across the evaporator. The organics were spiked into the evaporator pot in 10-ml ampoules each containing $0.01 \mathrm{~g}$ total organics in the portions as shown in Table 2-9. Initially 54 ampoules of the organics were added to 100 gallons in the evaporator pot on 9/16/03. After the initial charge, then the10-ml ampoules were added per 10 gallon of feed through $9 / 17 / 03$. During the period of the organic spikes, liquid and offgas samples were pulled and analyzed. Liquid samples were taken for the feed, concentrate, primary and secondary condensates. Details of the liquid organic sampling are contained in the BWXT report [8] [Westinghouse Savannah River Company BWXS Data reporting Package 0309037, BWXS-NELS Project Number 1199-011-23-70, SRTC Contract Number AB80151N (CO-7), Job 03477 - Evaporator Simulant, Characterization of Evaporator Simulant, October 10, 2003, BWXT Services, Inc, Nuclear Environmental Laboratory Services, Lynchburg, VA.]. Offgas samples were taken coming off the primary condenser using the EPA Method 0010. Details of the offgas sampling are detailed in the Air Tech reportv[9] [Memo to Zafar Qureshi, October 27, 2003, Air-Tech Environmental, LLC, Research Triangle Park, NC.].

Table 2-9. Organic Spike in 10-ml Ampoules

\begin{tabular}{|c|c|c|c|}
\hline Organic & Amount & Organic & Amount \\
\hline 1,4-Dinitrobenzene (100-25-4) & $0.00125 \mathrm{~g}$ & Hexachloroethane (67-72-1) & $0.00125 \mathrm{~g}$ \\
\hline N-Nitrosodimethlyamine (62-75-9) & $0.00125 \mathrm{~g}$ & Naphthalene (91-20-3) & $0.00125 \mathrm{~g}$ \\
\hline 1,2-Dibromoethane (106-93-4) & $0.00125 \mathrm{~g}$ & 2-Chloronaphthalen (91-58-7) & $0.00125 \mathrm{~g}$ \\
\hline Quinoline (91-22-5) & $0.00125 \mathrm{~g}$ & Diethylphthalate (84-66-2) & $0.00125 \mathrm{~g}$ \\
\hline
\end{tabular}

Table 2-10 and Table 2-13 show how the spiked organics partitioned across the evaporator streams. The volatile organic dibromoethane all went out into the evaporator overheads, but $97 \%$ was condensed out in the primary and secondary condensers with only about $3 \%$ going up into the offgas. Hexachloroethane primarily escaped into the offgas $(86 \%)$ with none coming out in the primary condenser and only $1 \%$ in the secondary condensers while the remainder (13\%) stays in the evaporator concentrate. Naphthalene was the next biggest organic to make it to the offgas system (23\%) with only $10 \%$ being captured by the primary and secondary condensers. A large portion of the Naphthalene $(67 \%)$ did remain behind in the evaporator concentrate. Both Hexachloroethane and Naphthalene sublime at temperatures below their melting points so as these components escape into the offgas stream as a vapor and are cooled down below their melting points, they sublime back into the offgas rather than condensing into the liquid phase. The other components don't readily sublime and thus little makes into the offgas stream from the condensers. Of the remaining Semivolatile organics, most were captured in the primary and secondary condensate with little remaining in the evaporator concentrate $(\leq 5 \%)$. 
Prior waste feed evaporator modeling [Daniel, W.E., Waste Feed Evaporator Off-Gas Emissions Modeling, Westinghouse Savannah River Co.: Aiken, SC 29808 (2002)] had looked at organic partitioning across the waste feed evaporator system. Unfortunately these earlier modeling results cannot be compared to the current pilot runs because the offgas model had a feed based on the Envelope B/D waste with Envelope C organic levels and a HAW SBS recycle where as the pilot work used an AN102 (Envelope C) waste and LAW SBS recycle. To try to compensate for these differences, the offgas model was re-run with a feed based on analyses of the AN-102 (Envelope C) waste and LAW SBS. Results from this modeling run are shown in Table 2-11.

For 1,2-Dibromoethane, naphthalene, and 2-Chloronaphthalene the model predicts more of these species goes up into the offgas than the pilot run. One reason for this difference is that the pilot run used a knock-out drum with demister pad, whereas the OLI model assumed only a $1 \%$ entrainment for its simulated demister. In the real world the knock-out drum may be more effective at reducing the offgas species than the simulated demister.

The model predictions for Hexachloroethane, Diethyl-phthalate, and Quinoline match more closely with the pilot values than for the other species. However there are still differences between the model predictions and the pilot run. The difference may be due to the pressure and temperature offsets between the OLI model and the actual pilot runs. The pilot runs were not instrumented to provide the necessary data required for proper modeling. Estimates of the various pressures used in the model may not match the actual pilot values. The offgas modeling parameters are shown in Table 2-12. By adjusting these model inputs, the organic splits could be made closer to the measured values. Without the necessary time and funding, the best estimates for the model inputs were chosen based on the limited information available.

Another reason for the discrepancy between the pilot work and OLI modeling is that the OLI model represents steady state simulation, i.e. not dynamic like the real process. The organic spiking and organic sampling occurred over a 2 hour period during which flow rates, temperature profiles, pressure profiles, and feed concentrations were changing. One more reason for the differences can be due to the solubility and sublimation characteristics of the species in OLI versus the real pilot work. 
WSRC-TR-2003-00561, REVISION 0

SRT-RPP-2003-00244, REVISION 0

Table 2-10. Percent Organic Partitioning Across Pilot Evaporator

\begin{tabular}{|c|c|c|c|c|c|c|c|c|}
\hline & $\begin{array}{c}\mathbf{1 , 2 -} \\
\text { Dibromo } \\
\text { ethane } \\
\mathbf{( 1 0 6 - 9 3 -} \\
\mathbf{4}\end{array}$ & $\begin{array}{c}\text { Hexachlo } \\
\text { roethane } \\
\mathbf{6 7 - 7 2 - 1 )}\end{array}$ & $\begin{array}{c}\text { Naphth- } \\
\text { alene } \\
\mathbf{( 9 1 - 2 0 - 3 )}\end{array}$ & $\begin{array}{c}\text { 2- } \\
\text { Chloro- } \\
\text { naphtha- } \\
\text { len (91- } \\
\mathbf{5 8 - 7 )}\end{array}$ & $\begin{array}{c}\text { Diethylp } \\
\text { hthalate } \\
\mathbf{( 8 4 - 6 6 - 2 )}\end{array}$ & $\begin{array}{c}\text { N- } \\
\text { Nitrosodi } \\
\text { methlya } \\
\text { mine (62- } \\
\mathbf{7 5 - 9 )}\end{array}$ & $\begin{array}{c}\text { Quinoline } \\
\text { (91-22-5) }\end{array}$ & $\begin{array}{c}\text { 1,4- } \\
\text { Dinitro- } \\
\text { benzene } \\
(\mathbf{1 0 0 - 2 5 - 4 )}\end{array}$ \\
\hline $\begin{array}{c}\text { Volatile } \\
\text { Organics }\end{array}$ & $\begin{array}{c}\text { Semi- } \\
\text { volatile } \\
\text { Organics }\end{array}$ & $\begin{array}{c}\text { Semi- } \\
\text { volatile } \\
\text { Organics }\end{array}$ & $\begin{array}{c}\text { Semi- } \\
\text { volatile } \\
\text { Organics }\end{array}$ & $\begin{array}{c}\text { Semi- } \\
\text { volatile } \\
\text { Organics }\end{array}$ & $\begin{array}{c}\text { Semi- } \\
\text { volatile } \\
\text { Organics }\end{array}$ & $\begin{array}{c}\text { Semi- } \\
\text { volatile } \\
\text { Organics }\end{array}$ & $\begin{array}{c}\text { Semi- } \\
\text { volatile } \\
\text { Organics }\end{array}$ \\
\hline Stream & $\%$ & $\%$ & $\%$ & $\%$ & $\%$ & $\%$ & $\%$ & $\%$ \\
\hline Feed & $0 \%$ & $0 \%$ & $0 \%$ & $0 \%$ & $0 \%$ & $0 \%$ & $0 \%$ & $0 \%$ \\
\hline $\begin{array}{c}\text { Primary } \\
\text { Condensate }\end{array}$ & $57 \%$ & $0 \%$ & $6 \%$ & $8 \%$ & $100 \%$ & $95 \%$ & $98 \%$ & $99 \%$ \\
\hline $\begin{array}{c}\text { Secondary } \\
\text { Condensate }\end{array}$ & $40 \%$ & $1 \%$ & $4 \%$ & $1 \%$ & $0 \%$ & $0 \%$ & $0 \%$ & $0 \%$ \\
\hline Offgas & $3 \%$ & $86 \%$ & $23 \%$ & $0 \%$ & $0 \%$ & $0 \%$ & $0 \%$ & $0 \%$ \\
\hline Concentrate & $0 \%$ & $13 \%$ & $67 \%$ & $91 \%$ & $0 \%$ & $5 \%$ & $2 \%$ & $1 \%$ \\
\hline
\end{tabular}

Table 2-11. Percent Organic Partitioning Across OLI Modeled Evaporator

\begin{tabular}{|c|c|c|c|c|c|c|c|c|c|}
\hline Stream & $\begin{array}{c}1,2- \\
\text { Dibromo- } \\
\text { ethane }\end{array}$ & $\begin{array}{c}\text { Hexachlo- } \\
\text { roethane }\end{array}$ & $\begin{array}{l}\text { Naph- } \\
\text { thalene }\end{array}$ & $\begin{array}{c}\text { 2-Chloro- } \\
\text { naphthalene }\end{array}$ & $\begin{array}{l}\text { Diethyl - } \\
\text { phthalate }\end{array}$ & $\begin{array}{c}\text { Phenol (sub } \\
\text { for N- } \\
\text { Nitroso- } \\
\text { dimethly- } \\
\text { amine) }\end{array}$ & Quinoline & $\begin{array}{c}1,4- \\
\text { Dinitro- } \\
\text { benzene }\end{array}$ & Ethanol \\
\hline \multicolumn{10}{|l|}{ Feed } \\
\hline $\begin{array}{c}\text { Primary } \\
\text { Condensate }\end{array}$ & $7.50 \%$ & $0.50 \%$ & $4.54 \%$ & $14.76 \%$ & $85.23 \%$ & $0.00 \%$ & $79.49 \%$ & $24.08 \%$ & $92.73 \%$ \\
\hline $\begin{array}{l}\text { Secondary } \\
\text { Condensate }\end{array}$ & $11.87 \%$ & $0.89 \%$ & $7.49 \%$ & $20.61 \%$ & $0.13 \%$ & $0.00 \%$ & $18.85 \%$ & $0.00 \%$ & $6.96 \%$ \\
\hline Offgas & $80.62 \%$ & $98.61 \%$ & $87.96 \%$ & $64.62 \%$ & $0.00 \%$ & $0.00 \%$ & $1.41 \%$ & $0.00 \%$ & $0.07 \%$ \\
\hline Concentrate & $0.01 \%$ & $0.00 \%$ & $0.01 \%$ & $0.01 \%$ & $14.64 \%$ & $100 \%$ & $0.25 \%$ & $75.92 \%$ & $0.24 \%$ \\
\hline
\end{tabular}

Table 2-12. OLI Evaporator Modeling Parameters

\begin{tabular}{|c|c|c|c|c|c|c|c|c|}
\hline Model Unit & Evaporator & $\begin{array}{c}\text { Primary } \\
\text { Condenser }\end{array}$ & $\begin{array}{c}\text { PC } \\
\text { Control } \\
\text { Air } \\
\text { Mixer }\end{array}$ & $\begin{array}{c}\text { Steam } \\
\text { Ejector 1 }\end{array}$ & $\begin{array}{c}\text { Inter- } \\
\text { Condenser }\end{array}$ & $\begin{array}{c}\text { Steam } \\
\text { Ejector } \\
\mathbf{2}\end{array}$ & $\begin{array}{c}\text { After } \\
\text { Condenser }\end{array}$ & $\begin{array}{c}\text { After } \\
\text { Condenser } \\
\text { Demister }\end{array}$ \\
\hline $\begin{array}{c}\text { Temperature, } \\
{ }^{\circ} \mathbf{C}\end{array}$ & 45 & 22 & adiabatic & adiabatic & 22 & adiabatic & 22 & 22 \\
\hline Pressure, psia & 0.995 & 0.385 & 0.366 & 3.29 & 3.13 & 15.44 & 14.7 & 14.7 \\
\hline
\end{tabular}


WSRC-TR-2003-00561, REVISION 0

SRT-RPP-2003-00244, REVISION 0

Table 2-13. Mass Organic Partitioning Across Pilot Evaporator

\begin{tabular}{|c|c|c|c|c|c|c|c|c|}
\hline & $\begin{array}{c}1,2- \\
\text { Dibromo } \\
\text { ethane } \\
(106-93- \\
4)\end{array}$ & $\begin{array}{c}\text { Hexachl } \\
\text { oroethan } \\
\text { e (67-72- } \\
1)\end{array}$ & $\begin{array}{c}\text { Naph- } \\
\text { thalene } \\
\text { (91-20- } \\
3)\end{array}$ & $\begin{array}{c}\text { 2- } \\
\text { Chlorona } \\
\text { phthalen } \\
(91-58-7)\end{array}$ & $\begin{array}{c}\text { Diethylp } \\
\text { hthalate } \\
\text { (84-66- } \\
2)\end{array}$ & $\begin{array}{c}\mathrm{N}- \\
\text { Nitrosod } \\
\text { imethlya } \\
\text { mine } \\
(62-75-9)\end{array}$ & $\begin{array}{l}\text { Quinoline } \\
(91-22-5)\end{array}$ & $\begin{array}{c}1,4- \\
\text { Dinitrob } \\
\text { enzene } \\
(100-25- \\
4)\end{array}$ \\
\hline & $\begin{array}{c}\text { Volatile } \\
\text { Organic } \\
\text { s }\end{array}$ & $\begin{array}{c}\text { Semi- } \\
\text { volatile } \\
\text { Organic } \\
\text { s }\end{array}$ & $\begin{array}{c}\text { Semi- } \\
\text { volatile } \\
\text { Organic } \\
\text { s }\end{array}$ & $\begin{array}{c}\text { Semi- } \\
\text { volatile } \\
\text { Organics }\end{array}$ & $\begin{array}{c}\text { Semi- } \\
\text { volatile } \\
\text { Organic } \\
\text { s }\end{array}$ & $\begin{array}{c}\text { Semi- } \\
\text { volatile } \\
\text { Organics }\end{array}$ & $\begin{array}{c}\text { Semi- } \\
\text { volatile } \\
\text { Organics }\end{array}$ & $\begin{array}{c}\text { Semi- } \\
\text { volatile } \\
\text { Organic } \\
\text { s }\end{array}$ \\
\hline Stream & $\mu \mathrm{g} / \mathrm{hr}$ & $\mu \mathrm{g} / \mathrm{hr}$ & $\mu \mathrm{g} / \mathrm{hr}$ & $\mu \mathrm{g} / \mathrm{hr}$ & $\mu \mathrm{g} / \mathrm{hr}$ & $\mu \mathrm{g} / \mathrm{hr}$ & $\mu \mathrm{g} / \mathrm{hr}$ & $\mu \mathrm{g} / \mathrm{hr}$ \\
\hline Feed & 0 & 0 & 0 & 0 & 0 & 636 & 609 & 0 \\
\hline $\begin{array}{c}\text { Primary } \\
\text { Condensate }\end{array}$ & 2511 & 148 & 2681 & 2211 & 2230 & 150,040 & 325,288 & 160,931 \\
\hline $\begin{array}{c}\text { Secondary } \\
\text { Condensate }\end{array}$ & 1753 & 375 & 1971 & 189 & 0 & 64 & 177 & 14 \\
\hline Offgas & 115 & 48,000 & 10,560 & 0 & 0 & 0 & 0 & 0 \\
\hline Concentrate & 0 & 7099 & 30,347 & 24,539 & 0 & 7812 & 6758 & 1268 \\
\hline
\end{tabular}

\subsubsection{Formation of Solids and Fouling}

The formation of solids was examined due to concerns over a plug in the concentrate transfer line just upstream of valve CL-BV5. Consequently, fouling of the reboiler tubes due to materials in the evaporator pot was also of concern. Solids formation occurred during the blending of the individual recycle streams prior to Evaporation Test 1. Samples of the initial feed streams and the concentrated slurry were taken during Evaporation Test 1 to determine what solids formed during the evaporation of the recycles. Results indicate the formation of sodium alumino-silicates and other solids during Test 1, as shown in Table 2-14. In earlier bench-scale experiments [M. E. Stone et al, Waste Feed Evaporation: Physical Properties and Solubility Determination(U), WSRC-TR-2003-00212, Rev. 0, WSRC, Aiken, SC 29808] for Envelope A recycle evaporation with 50\% SBS, gibbsite, bayerite, natrophosphate, and lithium aluminum hydroxide hydrate solids formed in the evaporator concentrate. The pilot evaporation concentrate also showed formation of bayerite and Lithium Aluminum Carbonate Hydroxide. 
WSRC-TR-2003-00561, REVISION 0

SRT-RPP-2003-00244, REVISION 0

Table 2-14. Solids in the Evaporator Run 1 Samples

\begin{tabular}{|c|c|c|c|}
\hline $\begin{array}{c}\text { Solids in HLW } \\
\text { Melter Offgas } \\
\text { Condensate }\end{array}$ & $\begin{array}{l}\text { Solids in UF } \\
\text { Recycle }\end{array}$ & $\begin{array}{c}\text { Solids in Evaporator } \\
\text { Feed }\end{array}$ & $\begin{array}{l}\text { Solids in Evaporator } \\
\text { Concentrate }\end{array}$ \\
\hline $\begin{array}{c}\text { Hematite } \\
\left(\mathrm{Fe}_{2} \mathrm{O}_{3}\right)\end{array}$ & N/A & Hematite $\left(\mathrm{Fe}_{2} \mathrm{O}_{3}\right)$ & Hematite $\left(\mathrm{Fe}_{2} \mathrm{O}_{3}\right)$ \\
\hline Quartz $\left(\mathrm{SiO}_{2}\right)$ & N/A & Quartz $\left(\mathrm{SiO}_{2}\right)$ & Quartz $\left(\mathrm{SiO}_{2}\right)$ \\
\hline N/A & Gibbsite $\left(\mathrm{Al}(\mathrm{OH})_{3}\right)$ & N/A & N/A \\
\hline N/A & Bayerite $\left(\mathrm{Al}(\mathrm{OH})_{3}\right)$ & Bayerite $\left(\mathrm{Al}(\mathrm{OH})_{3}\right)$ & Bayerite $\left(\mathrm{Al}(\mathrm{OH})_{3}\right)$ \\
\hline $\begin{array}{l}\text { Maghemite-C } \\
\left(\mathrm{Fe}_{2} \mathrm{O}_{3}\right)\end{array}$ & N/A & N/A & N/A \\
\hline N/A & N/A & Nordstrandite $\left(\mathrm{Al}(\mathrm{OH})_{3}\right)$ & Nordstrandite $\left(\mathrm{Al}(\mathrm{OH})_{3}\right)$ \\
\hline N/A & N/A & N/A & Nitratine $\left(\mathrm{NaNO}_{3}\right)$ \\
\hline N/A & N/A & Sodium Nitrite $\left(\mathrm{NaNO}_{2}\right)$ & Sodium Nitrite $\left(\mathrm{NaNO}_{2}\right)$ \\
\hline N/A & N/A & $\begin{array}{l}\text { Lithium Aluminum } \\
\text { Carbonate Hydroxide } \\
\left(\mathrm{Li}_{2} \mathrm{Al}_{4}\left(\mathrm{CO}_{3}\right)(\mathrm{OH})^{3} 3 \mathrm{H}_{2} \mathrm{O}\right)\end{array}$ & $\begin{array}{l}\text { Lithium Aluminum } \\
\text { Carbonate Hydroxide } \\
\left(\mathrm{Li}_{2} \mathrm{Al}_{4}\left(\mathrm{CO}_{3}\right)(\mathrm{OH}) \cdot 3 \mathrm{H}_{2} \mathrm{O}\right)\end{array}$ \\
\hline N/A & N/A & N/A & $\begin{array}{l}\text { Sodium Alumino-silicate } \\
\text { Hydrate } \\
\left(\mathrm{Na}_{2} \mathrm{Al}_{2} \mathrm{Si}_{15.7} \mathrm{O}_{36.4} 8 \mathrm{H}_{2} \mathrm{O}\right)\end{array}$ \\
\hline
\end{tabular}

The temperature of the reboiler (to maintain the desired boil-off rate) did not increase during Evaporator Test 1, indicating that very little fouling was occurring on the tubes. Visual observation of the interior of the heat exchanger tubes confirmed that very little fouling had occurred during Evaporator Test 1. The small amount of solids present on the tubes during Test 1 was easily removed by wiping. Visual examination indicates that the solids from Evaporator Run 1 are similar to the bulk solids in the concentrate stream. No other solids formation was observed in balance of the loop. This was checked by breaking the loop at the ball valve unions.

The splatter during Evaporator Test 1 led to a buildup of dried solids in the evaporator walls below the demister. These solids were very friable and easily removed by wiping. Antifoam was not added at the beginning of Test 1 to allow the foaming characteristics of the feed to be evaluated. The amount of splatter was significantly reduced by the antifoam addition.

Therefore the amount of solids buildup in this area of the evaporator is not representative. 
The solids that formed during Evaporator Test 2 are shown in Table 2-15. The solids were determined by first filtering the concentrate and submitting that filtered material for X-Ray Diffraction (XRD). This XRD was treated as representing the insoluble and some soluble species since it contained some interstitial supernate. The filtrate from the original concentrate sample was re-filtered, dried in a desiccator, and then submitted for XRD. This re-filtered desiccator sample was treated as a blank or representing the soluble solids. The difference between the original filtered sample and the re-filtered filtrate represented the insoluble species that actually formed. The only common solid between Evaporator Run 1 and 2 is Lithium Aluminum Carbonate Hydroxide Hydrate $\left.-\mathrm{Al}_{2} \mathrm{Li}(\mathrm{OH})_{6}\right)_{2} \mathrm{CO}_{3} \cdot \mathrm{xH}_{2} \mathrm{O}$. Evaporator Run 2 also did not show any evidence of the formation of Sodium Aluminosilicate Hydrate $\left(\mathrm{Na}_{2} \mathrm{Al}_{2} \mathrm{Si}_{15.7} \mathrm{O}_{36.4} 8 \mathrm{H}_{2} \mathrm{O}\right)$ like Run 1. In earlier bench scale evaporation experiments with envelope AN-102 feed [M. L. Crowder et al, Bench-Scale Evaporation of a Large Hanford Envelope C Sample (Tank 241-AN-102), WSRC-TR-2000-00469, WSRC, Aiken, SC, 29808], natroxalate, silica, natrophosphate, sodium nitrate, sodium carbonate hydrogen hydrate, and thermonatrite formed. The pilot 2 run also showed evidence of the formation of natroxalate, natrophosphate, sodium carbonate hydrogen hydrate, and thermonatrite in the evaporator concentrate and on the reboiler walls.

The only evidence of fouling or scaling occurred on 10/6/03 about 29 hours into the 100-hour boil, when a plug occurred in the concentrate loop. A sample of this plug was sent off for XRD. The results are shown in Table 2-15. The plug contains a lot of solids like bayerite, kogarkoite, natrophosphate, nitratine, thermonatrite, trona, and lithium aluminum carbonate hydroxide hydrate. However, the plug did not contain any sodium alumino-silicate hydrate. The plug in the concentrate line was attributed to loop configuration where a low velocity/ dead zone existed under certain valve settings. The concentrate line was reconfigured and no further pluggage was observed.

When the heat exchanger tubes of the reboiler were examined at the end of Evaporator Test 2, a few solids were found on the inside heat exchanger walls. A sample of that material was submitted for XRD and the results are shown in Table 2-15. The common solids between the heat exchanger scale and Evaporator Run 1 were Lithium Aluminum Carbonate Hydroxide Hydrate - $\left(\mathrm{Al}_{2} \mathrm{Li}(\mathrm{OH})_{6}\right)_{2} \mathrm{CO}_{3} \cdot \mathrm{xH}_{2} \mathrm{O}$ and Nitratine $\mathrm{NANO}_{3}$. This scale however was not significant. 
WSRC-TR-2003-00561, REVISION 0

SRT-RPP-2003-00244, REVISION 0

Table 2-15. Solids in Evaporator Run 2 Samples

\begin{tabular}{|c|c|c|}
\hline $\begin{array}{c}\text { Solids in Evaporator } \\
\text { Concentrate }\end{array}$ & $\begin{array}{c}\text { Solids in Evaporator Loop } \\
\text { Plug }\end{array}$ & $\begin{array}{c}\text { Solids on Reboiler Walls } \\
\text { at End of Run }\end{array}$ \\
\hline N/A & Bayerite $\left(\mathrm{Al}(\mathrm{OH})_{3}\right)$ & N/A \\
\hline Kogarkoite - $\mathrm{Na}_{3} \mathrm{FSO} 4$ & Kogarkoite $-\mathrm{Na}_{3} \mathrm{FSO} 4$ & Kogarkoite $-\mathrm{Na}_{3} \mathrm{FSO} 4$ \\
\hline $\begin{array}{c}\text { Natrophosphate } \\
\mathrm{Na}_{7} \mathrm{~F}\left(\mathrm{PO}_{4}\right)_{2}\left(\mathrm{H}_{2} \mathrm{O}\right)_{19}\end{array}$ & $\begin{array}{c}\text { Natrophosphate } \\
\mathrm{Na}_{7} \mathrm{~F}\left(\mathrm{PO}_{4}\right)_{2}\left(\mathrm{H}_{2} \mathrm{O}\right)_{19}\end{array}$ & $\mathrm{~N} / \mathrm{A}$ \\
\hline N/A & Nitratine $\mathrm{NANO}_{3}$ & Nitratine $\mathrm{NANO}_{3}$ \\
\hline $\begin{array}{l}\text { Thermonatrite } \mathrm{Na}_{2} \mathrm{CO}_{3} \text {. } \\
\qquad \mathrm{H}_{2} \mathrm{O}\end{array}$ & $\begin{array}{l}\text { Thermonatrite } \mathrm{Na}_{2} \mathrm{CO}_{3} . \\
\qquad \mathrm{H}_{2} \mathrm{O}\end{array}$ & N/A \\
\hline N/A & Trona - Na3H(CO3)2!2H2O & N/A \\
\hline $\begin{array}{c}\text { Lithium Aluminum } \\
\text { Carbonate Hydroxide } \\
\text { Hydrate - } \\
\left(\mathrm{Al}_{2} \mathrm{Li}(\mathrm{OH})_{6}\right)_{2} \mathrm{CO}_{3} \cdot \mathrm{xH}_{2} \mathrm{O}\end{array}$ & $\begin{array}{c}\text { Lithium Aluminum } \\
\text { Carbonate Hydroxide } \\
\text { Hydrate - } \\
\left(\mathrm{Al}_{2} \mathrm{Li}(\mathrm{OH})_{6}\right)_{2} \mathrm{CO}_{3} \cdot \mathrm{xH}_{2} \mathrm{O}\end{array}$ & $\begin{array}{c}\text { Lithium Aluminum } \\
\text { Carbonate Hydroxide } \\
\text { Hydrate - } \\
\left(\mathrm{Al}_{2} \mathrm{Li}(\mathrm{OH})_{6}\right)_{2} \mathrm{CO}_{3} \cdot \mathrm{xH}_{2} \mathrm{O}\end{array}$ \\
\hline Natroxalate $\mathrm{C}_{2} \mathrm{Na}_{2} \mathrm{O}_{4}$ & $\mathrm{~N} / \mathrm{A}$ & $\mathrm{N} / \mathrm{A}$ \\
\hline N/A & N/A & N/A \\
\hline N/A & $\mathrm{N} / \mathrm{A}$ & $\begin{array}{c}\text { Sodium Carbonate } \\
\text { Hydrogen Hydrate } \\
\mathrm{Na}_{2} \mathrm{CO}_{3} \mathrm{NaHCO}_{3}\left(\mathrm{H}_{2} \mathrm{O}\right)_{2}\end{array}$ \\
\hline N/A & $\mathrm{N} / \mathrm{A}$ & $\begin{array}{c}\text { Pirrsonite } \\
\mathrm{Na}_{2} \mathrm{Ca}\left(\mathrm{CO}_{3}\right)_{2} ! 2 \mathrm{H} 2 \mathrm{O}\end{array}$ \\
\hline
\end{tabular}


WSRC-TR-2003-00561, REVISION 0

SRT-RPP-2003-00244, REVISION 0

This page intentionally left blank. 


\subsection{FUTURE WORK}

The Pilot-Scale Evaporator was designed to concentrate a variety of waste streams under forced circulation and vacuum conditions. After completing three evaporation campaigns (one with water and two with simulated waste streams) described in this report, the evaporator is being prepared for use in the upcoming Hanford WTP Semi-Integrated Pilot Plant (SIPP) tests.

As the full-scale evaporator design/procurement is progressing, WTP can test or verify the performance of any of the evaporator subsystem such as demister, concentrate loop configuration, injection of antifoam agent etc. using the Pilot-Scale Evaporator. The PilotScale Evaporator can also be used to address issues during the startup or normal operations of the full-scale facility. 
WSRC-TR-2003-00561, REVISION 0

SRT-RPP-2003-00244, REVISION 0

This page intentionally left blank. 
WSRC-TR-2003-00561, REVISION 0

SRT-RPP-2003-00244, REVISION 0

\subsection{REFERENCES}

1. BNFL-003-98-0189, Revision 0, Envelopes A, B, and C Shaker/ Bath Evaporation Saturation Studies, P. R. Monson January 4, 2000, Westinghouse Savannah River Company, Aiken, South Carolina.

2. BNFL-003-98-0166, Revision 0, Evaporation of Hanford Envelope B Simulant (AZ-101) Preliminary Report, T. B. Calloway, January 6, 2000, Westinghouse Savannah River Company, Aiken, South Carolina.

3. BNFL-003-98-0080, Revision 0, Preliminary Modeling Results of Pretreated LAW Evaporator, A. S. Choi, June 1, 1999, Westinghouse Savannah River Company, Aiken, South Carolina.

4. T. B. Calloway, Evaporation of Hanford Envelope A Simulant (AN-105), WSRC-TR2000-00300, August 2000.

5. C. L. Crawford, et. al., Crucible-Scale Active Vitrification Testing Envelope A, Tank 241-AN103 (U), WSRC-TR-2000-00302, 9/15/2000.

6. H. H. Saito, et. al., AN-107 @ Simulant Bench-Scale LAW Evaporation with Organic Regulatory Analysis, WSRC-TR-2000-00486, Feb 2001

7. M. L. Crowder, Bench-Scale Evaporation of a Large Hanford Envelope C Sample (Tank 241-AN-102), WSRC-TR-2000-00469, Feb 2001

8. Westinghouse Savannah River Company BWXS Data reporting Package 0309037, BWXS-NELS Project Number 1199-011-23-70, SRTC Contract Number AB80151N (CO-7), Job 03477 - Evaporator Simulant, Characterization of Evaporator Simulant, October 10, 2003, BWXT Services, Inc, Nuclear Environmental Laboratory Services, Lynchburg, VA.

9. Memo to Zafar Qureshi, October 27, 2003, Air-Tech Environmental, LLC, Research Triangle Park, NC. 
WSRC-TR-2003-00561, REVISION 0

SRT-RPP-2003-00244, REVISION 0

This page intentionally left blank. 
WSRC-TR-2003-00561, REVISION 0

SRT-RPP-2003-00244, REVISION 0

\section{APPENDIX A. RECIPE FOR FIRST WASH}

Total volume of 1 st wash simulant

448.4 liters

\begin{tabular}{|r|l|l|r|}
\hline & Compounds & Formula & Mass (Grams) \\
\hline 1 & Sodium Chloride & $\mathrm{NaCl}$ & 1572.85 \\
\hline 2 & Sodium Fluoride & $\mathrm{NaF}$ & 1274.92 \\
\hline 3 & Sodium Sulfate & $\mathrm{Na} 2 \mathrm{SO} 4$ & 1130.38 \\
\hline 4 & Sodium Hydroxide & $\mathrm{NaOH}$ & 8955.68 \\
\hline 5 & Sodium Aluminate & $\mathrm{Na} 2 \mathrm{O} . \mathrm{Al} 2 \mathrm{O} 3.3 \mathrm{H} 2 \mathrm{O}$ & 13231.73 \\
\hline 6 & Sodium meta-silicate & $\mathrm{Na} 2 \mathrm{SiO} 3.9 \mathrm{H} 2 \mathrm{O}$ & 476.99 \\
\hline 7 & Sodium Oxalate & $\mathrm{Na} 2 \mathrm{C} 2 \mathrm{O} 4$ & 719.23 \\
\hline 8 & Sodium Phosphate & $\mathrm{Na3PO} 4.12 \mathrm{H} 2 \mathrm{O}$ & 2658.96 \\
\hline 9 & Sodium Carbonate & $\mathrm{Na} 2 \mathrm{CO} 3$ & 9939.10 \\
\hline 10 & Sodium Nitrate & NaNO3 & 32492.48 \\
\hline 11 & Sodium Nitrite & NaNO2 & 20721.33 \\
\hline 12 & Water & H2O & 422486.35 \\
\hline & & Final Mass & $\mathbf{5 1 5 6 6 0 . 0 0}$ \\
\hline & & Density (g/ml) & $\mathbf{1 . 1 5}$ \\
\hline
\end{tabular}


WSRC-TR-2003-00561, REVISION 0

SRT-RPP-2003-00244, REVISION 0

This page intentionally left blank. 
WSRC-TR-2003-00561, REVISION 0

SRT-RPP-2003-00244, REVISION 0

\section{APPENDIX B. RECIPE FOR SECOND WASH}

Total volume of 2 nd. wash simulant

448.4 liters

\begin{tabular}{|r|l|l|r|}
\hline & Compounds & Formula & Mass (Grams) \\
\hline 1 & Sodium Chloride & $\mathrm{NaCl}$ & 273.13 \\
\hline 2 & Sodium Sulfate & $\mathrm{Na} 2 \mathrm{SO} 4$ & 72.93 \\
\hline 3 & Sodium Hydroxide & $\mathrm{NaOH}$ & 11315.88 \\
\hline 4 & Sodium Aluminate & $\mathrm{Na} 2 \mathrm{O} . \mathrm{Al} 2 \mathrm{O} 3.3 \mathrm{H} 2 \mathrm{O}$ & 8887.72 \\
\hline 5 & Sodium meta-silicate & $\mathrm{Na} 2 \mathrm{SiO} 3.9 \mathrm{H} 2 \mathrm{O}$ & 258.06 \\
\hline 6 & Sodium Phosphate & $\mathrm{Na} 3 \mathrm{PO} 4.12 \mathrm{H} 2 \mathrm{O}$ & 287.03 \\
\hline 7 & Sodium Carbonate & $\mathrm{Na} 2 \mathrm{CO} 3$ & 1357.24 \\
\hline 8 & Sodium Nitrate & $\mathrm{NaNO} 3$ & 61.47 \\
\hline 9 & Sodium Nitrite & $\mathrm{NaNO} 2$ & 121.07 \\
\hline 10 & Water & $\mathrm{H} 2 \mathrm{O}$ & 446024.19 \\
\hline & & Final Mass & $\mathbf{4 6 8 6 5 8 . 7 2}$ \\
\hline & & Density (g/ml) & $\mathbf{1 . 0 4 5}$ \\
\hline
\end{tabular}


WSRC-TR-2003-00561, REVISION 0

SRT-RPP-2003-00244, REVISION 0

This page intentionally left blank. 
WSRC-TR-2003-00561, REVISION 0

SRT-RPP-2003-00244, REVISION 0

\section{APPENDIX C. RECIPE FOR LEACH}

Total volume of Leach simulant

62.32 liters

\begin{tabular}{|r|l|l|r|}
\hline & Compounds & Formula & Mass (Grams) \\
\hline 1 & Sodium Chloride & $\mathrm{NaCl}$ & 91.30 \\
\hline 2 & Sodium Sulfate & $\mathrm{Na} 2 \mathrm{SO} 4$ & 20.26 \\
\hline 3 & Sodium Hydroxide & $\mathrm{NaOH}$ & 4400.11 \\
\hline 4 & Sodium Aluminate & $\mathrm{Na} 2 \mathrm{O} . \mathrm{Al} 2 \mathrm{O} 3.3 \mathrm{H} 2 \mathrm{O}$ & 2616.50 \\
\hline 5 & Sodium meta-silicate & $\mathrm{Na} 2 \mathrm{SiO} 3.9 \mathrm{H} 2 \mathrm{O}$ & 75.63 \\
\hline 6 & Sodium Phosphate & $\mathrm{Na} 3 \mathrm{PO} 4.12 \mathrm{H} 2 \mathrm{O}$ & 52.38 \\
\hline 7 & Sodium Carbonate & $\mathrm{Na} 2 \mathrm{CO} 3$ & 495.40 \\
\hline 8 & Sodium Nitrate & $\mathrm{NaNO} 3$ & 13.67 \\
\hline 9 & Sodium Nitrite & $\mathrm{NaNO} 2$ & 39.26 \\
\hline 10 & Water & $\mathrm{H} 2 \mathrm{O}$ & 61682.29 \\
\hline & & Final Mass & $\mathbf{6 9 4 8 6 . 8 0}$ \\
\hline & & Density & $\mathbf{1 . 1 1 5}$ \\
\hline
\end{tabular}


WSRC-TR-2003-00561, REVISION 0

SRT-RPP-2003-00244, REVISION 0

This page intentionally left blank. 
WSRC-TR-2003-00561, REVISION 0

SRT-RPP-2003-00244, REVISION 0

\section{APPENDIX D. RECIPE FOR ACID CLEANING SOLUTION}

Total volume Acid Cleaning Solution

335.92 liters

\begin{tabular}{|r|l|l|r|}
\hline & Compounds & Formula & Mass (Grams) \\
\hline 1 & Aluminum Hydroxide & $\mathrm{Al}(\mathrm{OH}) 3$ & 899.93 \\
\hline 2 & Cadmium Nitrate & $\mathrm{Cd}(\mathrm{NO} 3) 2.4 \mathrm{H} 2 \mathrm{O}$ & 264.37 \\
\hline 3 & Chromium Nitrate & $\mathrm{Cr}(\mathrm{NO} 3) 3.9 \mathrm{H} 2 \mathrm{O}$ & 40.31 \\
\hline 4 & Ferric Nitrate & $\mathrm{Fe}(\mathrm{NO} 3) 3.9 \mathrm{H} 2 \mathrm{O}$ & 2442.81 \\
\hline 5 & Magnesium Nitrate & $\mathrm{Mg}(\mathrm{NO} 3) 2.6 \mathrm{H} 2 \mathrm{O}$ & 64.50 \\
\hline 6 & Manganese Nitrate & $\mathrm{Mn}(\mathrm{NO} 3) 2.6 \mathrm{H} 2 \mathrm{O}$ & 86.67 \\
\hline 7 & Nickel Nitrate & $\mathrm{Ni}(\mathrm{NO} 3) 2.6 \mathrm{H} 2 \mathrm{O}$ & 249.25 \\
\hline 8 & Nitric Acid & $\mathrm{HNO} 3$ & 40310.40 \\
\hline 9 & Phosphoric Acid & $\mathrm{H} 3 \mathrm{PO} 4$ & 29.56 \\
\hline 10 & Silica & $\mathrm{SiO} 2$ & 54.75 \\
\hline 11 & Sodium Nitrate & $\mathrm{NaNO} 3$ & 493.80 \\
\hline 12 & Zirconyl Nitrate & Zr(NO3)2 & 244.55 \\
\hline 13 & Water & $\mathrm{H} 2 \mathrm{O}$ & 312909.14 \\
\hline & & Final Mass & $\mathbf{3 5 8 0 9 0 . 0 4}$ \\
\hline & & Density (g/ml) & $\mathbf{1 . 0 6 6}$ \\
\hline
\end{tabular}


WSRC-TR-2003-00561, REVISION 0

SRT-RPP-2003-00244, REVISION 0

This page intentionally left blank. 